\title{
Training in bedrijven
}

Citation for published version (APA):

Smoorenburg, M. S. M., \& Heijke, J. A. M. (1995). Training in bedrijven. Researchcentrum voor Onderwijs en Arbeidsmarkt, Faculteit der Economische Wetenschappen. ROA Reports No. 6 https://doi.org/10.26481/umarep.1995006

Document status and date:

Published: 01/01/1995

DOI:

10.26481/umarep.1995006

Document Version:

Publisher's PDF, also known as Version of record

\section{Please check the document version of this publication:}

- A submitted manuscript is the version of the article upon submission and before peer-review. There can be important differences between the submitted version and the official published version of record.

People interested in the research are advised to contact the author for the final version of the publication, or visit the DOI to the publisher's website.

- The final author version and the galley proof are versions of the publication after peer review.

- The final published version features the final layout of the paper including the volume, issue and page numbers.

Link to publication

\footnotetext{
General rights rights.

- You may freely distribute the URL identifying the publication in the public portal. please follow below link for the End User Agreement:

www.umlib.nl/taverne-license

Take down policy

If you believe that this document breaches copyright please contact us at:

repository@maastrichtuniversity.nl

providing details and we will investigate your claim.
}

Copyright and moral rights for the publications made accessible in the public portal are retained by the authors and/or other copyright owners and it is a condition of accessing publications that users recognise and abide by the legal requirements associated with these

- Users may download and print one copy of any publication from the public portal for the purpose of private study or research.

- You may not further distribute the material or use it for any profit-making activity or commercial gain

If the publication is distributed under the terms of Article $25 \mathrm{fa}$ of the Dutch Copyright Act, indicated by the "Taverne" license above, 


\section{Training in bedrijven}

ROA-R-1995/6

M.S.M. van Smoorenburg

J.A.M. Heijke

\section{Researchcentrum voor Onderwijs en Arbeidsmarkt}

Rijksuniversiteit Limburg

Faculteit der Economische Wetenschappen en Bedrijfskunde

Maastricht, november 1995 


\section{CIP-GEGEVENS KONINKLIJKE BIBLIOTHEEK, DEN HAAG}

Smoorenburg, M.S.M. van

Training in bedrijven / M.S.M. van Smoorenburg, J.A.M. Heijke. - Maastricht : Researchcentrum voor Onderwijs en Arbeidsmarkt, Rijksuniversiteit Limburg, Faculteit der Economische Wetenschappen en Bedrijfskunde. - ([Rapport] I Researchcentrum voor Onderwijs en Arbeidsmarkt, ISSN 0922-8098; ROA-R1995/6)

Met lit. opg.

ISBN 90-5321-165-9

Trefw.: bedrijfsopleiding 


\section{Inhoudsopgave}

Bladzijde

1 Inleiding

1

2 Training in cijfers 5

2.1 Training internationaal gezien 5

2.2 Training in Nederland 9

$\begin{array}{ll}2.3 \text { Samenvatting } & 21\end{array}$

3 Training in de theorie $\quad 25$

3.1 Inleiding $\quad 25$

$\begin{array}{ll}3.2 \text { Training van buitenaf gezien } & 26\end{array}$

$\begin{array}{ll}3.3 \text { Training van binnenuit gezien } & 37\end{array}$

3.4 Conclusie en samenvatting 53

4 Training in de praktijk $\quad 57$

4.1 Inleiding $\quad 57$

4.2 Training in Europa $\quad 59$

4.3 Training in Nederland $\quad 67$

$\begin{array}{ll}\text { 4.4 Samenvatting en conclusie } & 89\end{array}$

5 Conclusie en samenvatting 93

$\begin{array}{ll}\text { Literatuur } & 97\end{array}$

$\begin{array}{ll}\text { Bijlage I } & 101\end{array}$

$\begin{array}{lr}\text { Bijlage II } & 103\end{array}$

$\begin{array}{ll}\text { Bijlage III } & 109\end{array}$ 


\section{Inleiding}

Onderwijs is een belangrijk goed. Voor de overheid is het de grootste post op de rijksbegroting, mensen zitten voor een kwart van hun leven op school en vele bedrijven beschouwen goed opgeleid en bekwaam personeel als hun belangrijkste activum. Al deze drie actoren hebben zo hun belangen om te investeren in onderwijs. De overheid zal denken aan de concurrentiepositie van 't land, de groei van de economie en aan de vergroting van het welzijn van de burgers. Mensen zullen bereid zijn te investeren in onderwijs omdat ze onder meer verwachten dat daardoor hun toekomstige inkomsten groter zullen zijn, ze aangenamer werk zullen kunnen verrichten en in het algemeen maatschappelijk beter zullen kunnen functioneren. Bedrijven zullen in eerste instantie denken aan de produktiviteit van hun werknemers, waarbij ook voor het personeelsmanagement een rol is weggelegd om deze te verhogen. Het is dan ook niet verwonderlijk dat personeelsfunctionarissen 'opleiding en training' ervaren als een belangrijke beleidsprioriteit (Hay-groep, 1991; Hoogedoorn, Walls \& Reincke, 1989). Het komen tot een beleid waarbij selectie, afvloeiing, opleiding, mobiliteit, beoordeling en beloning op elkaar zijn afgestemd ten einde de produktiviteit te verhogen, zal de verantwoordelijken de nodige hoofdbrekens bezorgen. Het creëren van een uitgekiend zowel integraal als effectief beleid is hierbij de opdracht. Maar bij het verwezenlijken van een dergelijke ambitieuze doelstelling komen steeds de posities en belangen van andere actoren in het vizier. Dit maakt de werkelijkheid vaak complex en weerbarstig.

In dit rapport gaat het om training in bedrijven. Training in bedrijven heeft te maken met alle bovengenoemde factoren en nog veel meer. Aan de hand van enkele conceptuele modellen zal training in bedrijven nader worden geanalyseerd en ingekaderd. Op basis van bestaande theorievorming zijn er verschillende wijzen om tegen relevante probleemstellingen aan te kijken. Hoofdstuk drie zal enkele zienswijzen presenteren die elkaar soms aanvullen maar soms ook uitsluiten. Dat dit niet zo'n probleem hoeft te zijn, bewijst de populariteit van het boek Images of Organizations (Morgan, 1986), waarin de auteur geheel verschillende zienswijzen presenteert om naar organisaties te kijken. Het derde hoofdstuk wordt geflankeerd door het tweede en het vierde hoofdstuk. In het tweede hoofdstuk komt enig feitelijk cijfermateriaal over training in bedrijven aan de orde, dat voor zover nodig in een internationale context wordt geplaatst. Het tweede hoofdstuk leunt voor een groot deel op een door het Centraal Bureau voor de Statistiek (CBS) uitgevoerd onderzoek naar bedrijfsopleidingen, maar er zijn ook diverse aanvullende gegevens in verwerkt. Het vierde hoofdstuk gaat over training in de praktijk. Er worden impressies gegeven van training in bedrijven, op grond van enkele bedrijfsbezoeken. Het hoofdstuk heeft geenszins de pretentie volledig, representatief of generaliseerbaar te zijn. De waargenomen praktijk in bedrijven biedt slechts voorbeelden voor het 
verkennen van probleemstellingen voor een uit te voeren trainingsbeleid, het vergelijkenderwijs nadenken over de diverse aspecten van training en het confronteren van de trainingspraktijk met bestaande veronderstellingen of inzichten.

De concrete aanleiding tot het onderhavige rapport was het verzoek van het 'Institute for Employment Research' (IER) - dat geassocieerd is met de University of Warwick (GB) - om deel te nemen aan het onderzoeksproject genaamd 'The Costs and Benefits of Training'. Het IER had in 1992 de opdracht gekregen van de 'Task Force on Human Resources, Education and Youth' van de Commissie van de Europese Gemeenschappen om enkele analytische benaderingen te ontwikkelen met de volgende doeleinden:

- het beschouwen van de relatief sterke en zwakke punten van de verschillende nationale trainingsystemen door in het bijzonder te letten op de opbrengsten van training voor bedrijven;

- het identificeren van sterke en zwakke sectorale trainingsstrategieën;

- het identificeren van strategische issues voor de Europese Gemeenschap.

Het onderzoek betrof het verzamelen, inventariseren en synthetiseren van bestaand onderzoeksmateriaal over onderwijs en training in een zestal Europese landen (leidend tot zes zogenaamde 'synthesis studies') en het in elk land uitvoeren van acht case-studies verdeeld over vier sectoren. Het Researchcentrum voor Onderwijs en Arbeidsmarkt (ROA) van de Rijksuniversiteit Limburg heeft met financiële steun van de Europese Commissie het Nederlandse gedeelte van het onderzoek voor zijn rekening genomen. Dit heeft geleid tot het inventariserende paper The Costs of Not Training (De Grip, Heijke \& Willems, 1992), tot het Nederlandse syntheserapport en tot een verslag over de acht Nederlandse casestudies. Het IER heeft de Nederlandse bijdragen tezamen met de bijdragen van de overige participerende instellingen (IFO in Duitsland; ESRI in lerland; IREDU in Frankrijk en CIREM in Spanje) verwerkt in een tweetal rapporten (Lindley \& Hogarth, 1992 en Lindley \& Hogarth, 1993). Het rapport dat nu voor u ligt is gebaseerd op het in Nederland verzamelde onderzoeksmateriaal, maar gebruikt ook (met name in hoofdstuk 4) de conclusies en interpretaties zoals deze zijn verwoord in het eindrapport van Lindley \& Hogarth. Daarnaast bestond bij het ROA de behoefte om het reeds aanwezige (maar enigszins versnipperde) basismateriaal aan te vullen met nadere informatie en analyses (hoofdstuk 2) en met nadere theorievorming (hoofdstuk 3), opdat sprake zou kunnen zijn van een afgerond en geïntegreerd Nederlands rapport betreffende training in bedrijven.

De auteurs van dit rapport, drs. M.S.M. van Smoorenburg en prof. dr. J.A.M. Heijke, zijn dank verschuldigd aan hun collega's dr. A. de Grip en dr. R.K.W. van der Velden, die in de eerste fase van het onderzoek een begeleidende en adviserende rol hebben vervuld. Verder worden M. Hamers, drs. R. Silfhout en drs. $H$. Uyterhagen bedankt voor hun constructieve commentaar op een eerdere versie van 
hoofdstuk drie. Tot slot, maar zeker niet in de laatste plaats, willen wij de onderzochte bedrijven en de welwillende geïnterviewden danken voor hun medewerking en hun openhartigheid. 
......... 


\section{Training in cijfers}

\subsection{Training internationaal gezien}

In dit hoofdstuk wordt een statistisch overzicht gegeven van het verschijnsel training. Omdat Nederland een klein land is, is het voor de gedachtenvorming goed om Nederland te vergelijken met andere landen. Deze internationale vergelijking is het onderwerp van deze paragraaf. In de volgende paragraaf wordt de training in Nederland wat verder uitgediept. Het hoofdstuk wordt afgesloten met een samenvattende conclusie.

"Het zou onjuist zijn investeringen in mensen tot een eenvoudige economische rekensom te reduceren. Met het menselijk potentieel zijn fundamentele politieke en sociale waarden gemoeid. Desniettegenstaande heeft nog steeds niet iedereen volledig begrepen dat investeringen in menselijke hulpbronnen een sleutelrol spelen bij het waarborgen van commercieel succes op de mondiale markt", aldus het Groenboek voor een Europees Sociaal Beleid van de Commissie van de Europese Gemeenschappen (Flynn, 1993). De omvang en samenstelling van het menselijk kapitaal hebben dus niet alleen een sociale, culturele en politieke betekenis, ze zijn ook medebepalend voor de internationale concurrentiekracht van bedrijven, bedrijfstakken of landen. Dit menselijke kapitaal is al lang geen 'residual factor' meer in de verklaring van de economische groei. Het is dan ook niet vreemd dat een stroom van (internationale) onderzoeken naar onderwijs en training is losgekomen, waarbij aanvankelijk beschrijvende statistieken de boventoon voerden maar nu langzamerhand ook verklarende analyses verschijnen.

De training die in bedrijven plaatsvindt kan niet los worden gezien van het vigerende onderwijssysteem noch van de waarden en tradities in een land. Enige notie van de interacties die hiertussen bestaan, kan het beste worden verkregen door 'in te zoomen' op de variatie in initiële, reguliere onderwijssystemen, oftewel door een globale vergelijking van landen te maken. In kader 2.1 zijn enkele dominante kenmerken van de onderwijssystemen van vijf landen puntsgewijs samengevat, zonder daarbij de illusie te koesteren volledig te willen zijn. Het is louter bedoeld als illustratie van de variëteit in onderwijssystemen in een aantal vooraanstaande OESO-landen.

Bij de vergelijking van trainingstatistieken tussen landen moet tenminste met twee zaken rekening worden gehouden. Namelijk de verschillende positie van het reguliere onderwijssysteem en het bestaan van definitie- en methodische verschillen. 
Kader 2.1

De belangrijkste onderwijs- en trainingskenmerken per land

DUITSLAND:

Grote nadruk op het initiële beroepsonderwijs (inclusief leerlingwezen) en minder op postinitiële volwasseneneducatie (TFHR, 1993)

- een secundaire rol van de overheid (TFHR, 1992)

- een zeer dominant duaal systeem: ruim tweederde van de 16-19 jarigen doorloopt (een gedeelte van) het duale traject (Aalders, 1994);

- een duaal stelsel dat zich kenmerkt door een 'grote decentrale invulling, met een hoofdrol voor de sociale partners. Op regionaal niveau beslissen de sociale partners over he regionale opleidingsbeleid, stellen exameneisen op, nemen examens af, zien toe op de invulling van de praktijkcomponent in bedrijven en registreren de contracten (Aalders, 1994).

FRANKRIJK:

- In het Franse onderwijsstelsel ligt een grote nadruk op algemene vorming (Aalders, 1994) en op continue post-initiële volwasseneneducatie (TFHR, 1993)

- het leerlingwezen heeft een relatief kleinere omvang dan in Nederland,...beperkt zich to enkele bedrijfstakken.... en vooral kleinere bedrijven participeren in het leerlingwezen (Aalders, 1994):

- de rol van de sociale partners in het opleidingsbeleid is beperkt (Aalders, 1994);

- een staatsgereguleerd model (Auer, 1992)

wettelijke plicht voor bedrijven om een bepaald percentage van de loonsom te besteden aan formation professionelle continue. De wet leidde tot een aanmerkeliike verhoging van de opleidingsuitgaven (vooral bi de kleinste bedrijven), maar heeft gefaald in het wegnemen van de ongelijke deelname aan opleidingen naar sexe en opleidingsniveau (Aalders, 1994).

GROOT BRITTANNIË:

- De onderwijsdeelname op het 18 de levensjaar is met $34 \%$, op Portugal, na het laagste van Europa (cijfers over 1986: CEDEFOP, 1990a) ofschoon wel sprake is van een inhaalrace, aangezien sinds 1986 de deelnamecijfers van 16-18-jarigen met enkele procentpunten per jaar stijgen (Aalders, 1994);

- bestuurlijk zijn grote veranderingen aan de gang in het Britse onderwijs...enerzijds krijgen scholen meer vrijheid door een lump sum financiering .....anderzijds vindt ook gedeeltelijk centralisatie van de macht plaats (Aalders, 1994)

- het leerlingwezen vindt tegenwoordig bijna geheel in Youth Training-verband plaats (enigszins vergelijkbaar met het Nederlandse Jeugdwerkgarantieplan) ... en over het (enigszins vergelijkbaar met het Nederlandse Jeugdwerkgarantieplan

- niveau van (bedrijfsgebonden) training is voornamelijk de verantwoordelijkheid van werkgevers en overheidsuitgaven op het gebied van training zijn gericht op kansarme werkgevers en overheidsuitgaven op het

- $\quad$ groepen op de arbeidsmarkt (TFHR, 1992) (Lindley \& Hogarth, 1993).

NEDERLAND:

een goed en toegankelijk initieel onderwijssysteem met zowel naar niveau als naar richting een uitgebreide differentiatie in het beroepsonderwijs;

- de overheidsuitgaven voor onderwijs zijn relatief hoog (Houtkoop \& Felix, 1990)

- een beperkte overheidszorg voor de scholing van werkenden in het bedrijfsleven (Bronneman-Helmers, 1992)

- bedrijfstakgebonden afspraken tussen werkgevers(-verenigingen) en vakbonden over scholing, soms leidend tot opleidingsfondsen;

- het midden- en kleinbedriif maakt veel gebruik van het opleidingsaanbod van brancheorganisaties (Houtkoop \& Felix, 1990);

- de particuliere opleidingen hebben een relatief sterke positie op de markt van bedrijfsopde particulie onlangs ingevoerde wettelijke mogelijkheden voor contractonderwijs zullen de kansen van de publieke sector op deze markt verbeteren. (Houtkoop \& Felix, 1990).

VERENIGDE STATEN:

- Een kwart van de Amerikaanse beroepsbevolking heeft een College-diploma.... en met $6,4 \%$ van het nationaal inkomen besteed aan onderwijsuitgaven zit de VS licht boven het O'ESO-gemiddelde (cijfers 1986/1987; OESO, 1990a uit Aalders, 1994);

- tegenover de niet geringe omvang van de onderwijsdeelname staat het gebrekkige kennisniveau van de middelbare scholier, het gebrekkige niveau in taal en rekenen en de hoge drop-out (o.b.v. Aalders, 1994):

- het leerlingwezen is in de Vs zwak ontwikkeld, dit in tegenstelling tot het voltijds beroepsonderwijs (Aalders, 1994 )

- beperkte deelname aan formele (bedrijfsgebonden) training door jongeren (OECD, 1993). 
Om te beginnen met de verschillen tussen de onderwijssystemen wordt het volgende citaat aangehaald:

"Trainingstrategieën van bedrijven en meer in zijn algemeenheid van betrokken partijen bij CVT (=Continuing Vocational Education), variëren aanzienlijk tussen landen, met als resultaat dat werkgevers niet altijd hetzelfde aandeel nemen in de verantwoordelijkheid voor het financieren van CVT. Tussen de verschillende landen moet een onderscheid worden gemaakt op basis van de dominante vorm van interventie door organisaties. Deze kan zich namelijk concentreren op het initiële beroepsonderwijs (m.n. Duitsland en Nederland) of op het continue onderwijs (Frankrijk en in mindere mate Spanje). Dit kan leiden tot substitutie-effecten tussen de financiering van het initiële beroepsonderwijs versus het continue onderwijs door organisaties, hetgeen een factor vormt waarmee rekening moet worden gehouden bij de beoordeling van de relatieve positie van landen' (TFHR, 1993)."

Over definitie- en methodische verschillen wordt in de Employment Outlook van 1991 (OECD, 1993) gesteld dat:

"The definitions of and questions on training, reference periods, population or enterprise coverage and survey methods differ from one country to another, and within countries from one type of survey to another. Each of these factors will affect any attempt to compare the statistics."

Even verderop wordt een voorbeeld gegeven:

"A widely available statistic is the incidence of training. Thought of simply, this is the number of employees undergoing training divided by employment. But practice is straightforward with respect to neither the numerator nor the denominator".

Bij de bepaling van de teller speelt bijvoorbeeld een rol of ook on-the-job training en het leerlingwezen meegeteld worden en is bovendien de referentieperiode van belang. Bij de bepaling van de noemer dient men alert te zijn op de samenstelling van de onderzochte groep mensen, namelijk een bepaalde leeftijdscategorie, de werkzame beroepsbevolking, schoolverlaters, etc.

In het bewustzijn van bovengenoemde beperkingen, wordt toch een poging gedaan de Nederlandse trainingsintensiteit enigszins te positioneren ten opzichte van het buitenland. In de Employment Outlook van 1991 wordt een aantal landen (Australië, Finland, Japan, Nederland, Noorwegen, Verenigde Staten) op het gebied van diensttijd, verloop en training met elkaar vergeleken. Uit deze gegevens blijkt dat in Japan $79 \%$ van degenen die maximaal een jaar geleden bij een bedrijf in dienst is 
getreden, in dat jaar formele bedrijfstraining heeft gehad. In de Verenigde Staten heeft slechts $8 \%$ van degenen die maximaal een jaar geleden bij een bedrijf in dienst zijn getreden, in dat jaar formele bedrijfstraining ontvangen (beiden betreffende het jaar 1991). Voor de zes onderzochte landen zijn dit de beide extremen. Nederland scoort met $19 \%$ aan de lage kant. De Nederlandse data zijn gebaseerd op het OSA-arbeidsaanbodpanel van 1990. Dit betreft een longitudinale studie waarbij gevraagd wordt of men de afgelopen twee jaar formele bedrijfstraining heeft gehad. Het genoemde percentage van $19 \%$ heeft betrekking op de groep werknemers die maximaal een jaar in dienst is bij de huidige werkgever. Overigens blijkt ook uit de OECD-vergelijking dat het vóórkomen van formele bedrijfstraining toeneemt tot zo'n 20 jaar diensttijd en daarna afneemt. Alleen in Japan is dit verband tussen diensttijd en formele bedrijfstraining niet waar te nemen, aangezien hier het vóórkomen van formele bedrijfstraining gedurende het gehele arbeidsleven hoog is.

In het volgende hoofdstuk zal nog nader worden ingegaan op de relatie tussen diensttijd en training. Uit bovenstaande alinea kan in ieder geval worden opgemaakt dat het in Japan zeer waarschijnlijk is dat een werknemer die pas in dienst getreden is een formele bedrijfstraining krijgt, dat die kans in de Verenigde Staten aanzienlijk geringer is en dat wat dit betreft Nederland meer gelijkenis vertoont met de Verenigde Staten dan met Japan.

Tabel 2.1

Deelname en kosten van bedrijfsopleidingen, private sector

\begin{tabular}{|c|c|c|c|c|c|}
\hline & Jaar & $\begin{array}{l}\text { Deelname }^{a} \\
\text { excl. leerling- } \\
\text { wezen }\end{array}$ & $\begin{array}{l}\text { Deelname } \\
\text { incl. leerling- } \\
\text { wezen }\end{array}$ & $\begin{array}{l}\text { Kosten/ } \\
\text { Loonsom } \\
\text { excl. leerling- } \\
\text { wezen }\end{array}$ & $\begin{array}{l}\text { Kosten/ } \\
\text { Loonsom } \\
\text { incl.leerling- } \\
\text { wezen }\end{array}$ \\
\hline $\begin{array}{l}\text { Nederland } \\
\text { GB } \\
\text { Duitsland } \\
\text { Frankrijk } \\
\text { VS }\end{array}$ & $\begin{array}{l}1986 \\
1987 \\
1987 \\
1987 \\
1987\end{array}$ & $\begin{array}{l}0.25 \\
0.37 \\
0.32 \\
0.40 \\
0.33\end{array}$ & $\begin{array}{l}0.28 \\
0.40 \\
0.41 \\
0.42 \\
0.33\end{array}$ & $\begin{array}{l}1,4 \% \\
1,8 \% \\
1,8 \% \\
1,3 \% \\
1,7 \%\end{array}$ & $\begin{array}{l}2,0 \% \\
2,6 \% \\
5,8 \% \\
1,7 \% \\
2,1 \%\end{array}$ \\
\hline
\end{tabular}

a Het aantal cursussen per werknemer. Er is aangesloten bij het werknemersbestand dat ten grondslag ligt aan de verschillende nationale enquêtes. Een cursist die twee of meer cursussen heeft gevolgd, telt even zovele malen mee.

b Uitgaven als percentage van de bruto-Ioonson van de private sector. Voor Groot-Brittannië en Duitsland is de loonsom gecorrigeerd voor landbouw en visserij.

Bron: Aalders, 1994

Ofschoon er in tabel 2.1 van minder recente gegevens wordt uitgegaan (19861987), zijn hieruit toch enkele interessante conclusies te trekken. De tabel en de interpretatie zijn overgenomen uit Aalders (1994). 
"Wat opvalt zijn de relatief geringe verschillen tussen de landen. Overal zit men rond de $1,5 \%$ van de loonsom. De deelname loopt meer uiteen. Wordt het leerlingwezen inbegrepen, dan grijpt Duitsland de koppositie. Verder is de hoge score van Duitsland en Groot-Brittannië een gevolg van een hoger aantal leerlingen. Dit bevestigt de stelling dat deze landen meer gekenmerkt worden door de aanwezigheid van beroepsdeelmarkten, in tegenstelling tot Frankrijk en Italië, waar meer op interne arbeidsmarkten gebouwd wordt en de nadruk meer op on-the-job training ligt (verwezen wordt naar Marsden \& Ryan, 1990)...... Op basis van deze data kan Nederland inderdaad tot de achterblijvers worden gerekend, al zijn de verschillen niet scherp of dramatisch groot. Bovendien loopt Nederland in de enquêtes een jaar 'achter', wat bij een stijgende trend in het nadeel werkt. Men mag niet op basis van deze uitkomsten alléén een oordeel vellen over de score van een land. Mogelijk is dat een volgroeid systeem van regulier beroepsonderwijs eenvoudigweg minder tot bijscholing gedurende het werkzame leven noopt. Auer wees hier al op toen hij stelde dat de hoge opleidingsscore van Groot-Brittannië wellicht te verklaren was uit hun mindere initiële (beroeps)onderwijs" (Aalders, 1994).

Uit een internationaal vergelijkende studie van Hoevenberg en De Grip (1994) blijkt dat de Nederlandse participatiegraad in duaal onderwijs veel lager ligt dan in Denemarken en (West) Duitsland en ook lager ligt dan in Frankrijk en GrootBrittannië. Van de negen vergeleken Europese landen scoort Nederland de derde positie wat betreft on-the-job-training, behoorlijk ver verwijderd van beide koplopers Groot-Brittannië en Denemarken. Nederland heeft verder de op een na hoogste onderwijsuitgaven als percentage van het BNP, maar het tempo waarin dit daalt is het hoogste van alle vergeleken landen.

\subsection{Training in Nederland}

In de vorige paragraaf kwamen enkele internationaal vergelijkende indicatoren van training aan de orde, terwijl nu de training in Nederland centraal staat. In de onderhavige paragraaf wordt onder meer ingegaan op de hoogte en samenstelling van de opleidingskosten voor het bedrijfsleven, op de ontwikkeling van de opleidingskosten ten opzichte van het verleden en op de verdeling van opleidingen naar bedrijfsgrootte, bedrijfstak, geslacht en opleidingsniveau. Speciale aandacht wordt gevestigd op de training van schoolverlaters op de arbeidsmarkt. Voor deze groep wordt onder meer de kans op training geschat.

Het Centraal Bureau voor de Statistiek (CBS) heeft in 1990 een omvangrijk onderzoek gedaan naar bedrijfs- en externe opleidingen in de particuliere sector (CBS, 1992). Het CBS verstaat onder een bedrijfsopleiding een opleiding die uitsluitend 
toegankelijk is voor personen die werken bij het geënquêteerde bedrijf of instelling, of bij een moeder-, dochter- of zusterbedrijf van het geënquêteerde bedrijf (besloten inschrijving). Externe opleidingen zijn opleidingen die ook toegankelijk zijn voor personen die niet werken bij het geënquêteerde bedrijf of instelling, of bij een moeder-, dochter- of zusterbedrijf van het geënquêteerde bedrijf (open inschrijving). Buiten deze CBS-definitie van 'opleidingen' vallen onder meer opleidingen in het kader van het leerlingwezen, leren tijdens het werk (on-the-job learning) inclusief interne en externe stages en cursussen voor klanten en afnemers. De gegevens hebben betrekking op een populatie van ruim 71.000 bedrijven in de particuliere sector met 5 of meer werknemers (in totaal 3,3 miljoen werknemers). Er is gewerkt met een tweetraps gestratificeerde steekproef waarbij uiteindelijk 5.100 bedrijven een tweede, uitgebreide vragenlijst hebben ontvangen.

In 1990 bedroegen in Nederland de bedrijfskosten van bedrijfs- en externe opleidingen 3 miljard gulden, dit is $1,7 \%$ van de directe arbeidskosten. Per werknemer is gemiddeld $f 900$ uitgegeven, terwijl per deelname $f 2.700$ is besteed. Circa $40 \%$ van de kosten van opleidingen bestond uit de kosten van gederfde arbeidstijd. Van de gevolgde opleidingen betrof $35 \%$ een externe opleiding, maar bij de kleinere bedrijven lag dit percentage een stuk hoger. Het CBS heeft ook het aantal opleidingen c.q. deelnames per werknemer berekend. Gemiddeld werden in 1990 0,34 opleidingen per werknemer gevolgd. Voor alle duidelijkheid moet worden gesteld dat dit niet betekent dat $34 \%$ van de werknemers in dat jaar een cursus heeft gevolgd, omdat werknemers ook meerdere cursussen in een jaar kunnen volgen.

Door het CBS was in 1986 een soortgelijk onderzoek uitgevoerd (CBS, 1988 en CBS, 1992). De kosten van bedrijfs- en externe opleidingen bedroegen toen $1,5 \%$ van de directe arbeidskosten. De stijging van $1,5 \%$ in 1986 tot $1,7 \%$ in 1990 is niet spectaculair te noemen. Ten einde meer zicht te krijgen op de achtergronden van deze ontwikkeling wordt de stijging in drie factoren ontleed:

- het aantal opleidingen per werknemer van 1990 t.o.v. 1986;

- de kosten per opleiding in 1990 t.o.v. 1986;

- de directe arbeidskosten in 1990 t.o.v. 1986.

$\mathrm{Nu}$ blijkt dat er tegenover het veel hogere aantal opleidingen per werknemer (in 1986 was het aantal opleidingen per werknemer 0,25 en in 19900,34 ) een daling van de kosten per opleiding staat (van $f 3.000$ per opleiding in 1986 tot $f 2.700$ in 1990). Deze daling van de kosten per opleiding tezamen met de lichte stijging van de directe arbeidskosten leidden ertoe dat bovengenoemde stijging van $1,5 \%$ tot $1,7 \%$ beperkt kon blijven, zeker als men dit relateert aan de forse stijging van het aantal opleidingen per werknemer. Met andere woorden, de lichte stijging van de opleidingskosten als percentage van de directe arbeidskosten is de resultante van 
drie effecten:

- een forse stijging van het aantal opleidingen per werknemer;

- een daling van de gemiddelde kosten per opleiding;

- een lichte stijging van de gemiddelde directe arbeidskosten.

Op basis van de CBS-data kan niet worden afgeleid of de spreiding van opleidingen over de werknemers groter of kleiner is geworden. Het kan zijn dat meer werknemers goedkopere opleidingen volgen of dat enkele duurdere opleidingen verruild zijn voor meerdere goedkopere opleidingen. Een derde mogelijkheid is dat bij een gegeven inhoud van een opleiding de prijs tussen 1986 en 1990 is gedaald wat niet geheel onwaarschijnlijk is gezien de hevige concurrentie op de opleidingsmarkt. Hoe het ook zei, in reële termen is het aantal opleidingen per werknemer tussen 1986 en 1990 fors toegenomen en wel met $36 \%$.

\section{Omvang en soort organisaties}

Een andere conclusie die uit de CBS-onderzoeken van 1986 en 1990 kan worden getrokken, is het feit dat er sprake is van een grote spreiding van de opleidingsindicatoren (zoals het aantal opleidingen per werknemer, de opleidingskosten per werknemer, de opleidingskosten als percentage van de directe arbeidskosten) over de verschillende bedrijfstakken. Uit internationaal vergelijkende studies (zie OECD, 1991) blijkt ook dat er tussen bedrijfstakken een enorme variatie in opleidingsparticipatie en relatieve opleidingskosten bestaat en dat sommige bedrijfstakken in alle landen hoog scoren (zoals de financiële sector), terwijl andere bedrijfstakken in alle landen laag scoren (zoals de textiel-industrie). Aalders (1994) merkt ook op dat de bedrijfsklasse-rangschikking per land een grotendeels overeenkomend patroon te zien geeft, ofschoon enige diversiteit niet geheel afwezig is.

Een volgend gegeven dat uit diverse onderzoeken blijkt, is dat de opleidingsindicatoren sterk variëren naar organisatiegrootte, in die zin dat grotere organisaties relatief gesproken meer aan opleidingen doen dan kleinere organisaties. We zullen in het hierna volgende een en ander trachten te staven en nader aan te vullen door middel van enkele secundaire analyses op de CBS-gegevens en de gegevens van twee grote schoolverlatersonderzoeken. De grote verschillen naar zowel bedrijfstak als organisatiegrootte impliceren, dat de structuur van de werkgelegenheid in een land zeer bepalend is voor de omvang en deelname aan bedrijfs- en externe opleidingen.

Tabel 2.2 geeft aan dat er grote verschillen naar bedrijfsgrootte zijn in de omvang en structuur van de bedrijfs- en externe opleidingen (CBS, 1992). In zowel 1986 als 1990 zijn de opleidingskosten als percentage van de directe arbeidskosten in bedrijven met minimaal 500 werknemers 5 à 6 keer zo hoog als in bedrijven met 
tussen de 5 en 100 werknemers. De opleidingskosten per werknemer zijn in bedrijven met tenminste 500 werknemers ook 6 keer zo hoog als in bedrijven met tussen de 5 en 100 werknemers (deze indicator is niet opgenomen in de tabel). Als gekeken wordt naar het aantal opleidingen per werknemer, dan kan geconstateerd worden dat ook deze opleidingsindicator bij grote bedrijven veel hoger is dan bij kleine bedrijven ( 4 à 5 keer zo groot). De verschillen naar bedrijfsgrootte ten aanzien van deze drie opleidingsindicatoren zijn tussen 1986 en 1990 wel enigszins afgenomen. Verder blijkt uit de tabel dat kleine bedrijven veel vaker gebruik maken van externe opleidingen ten opzichte van bedrijfsopleidingen, dan grote bedrijven.

Tabel 2.2

Omvang en structuur van bedrijfs- en externe opleidingen naar grootteklasse

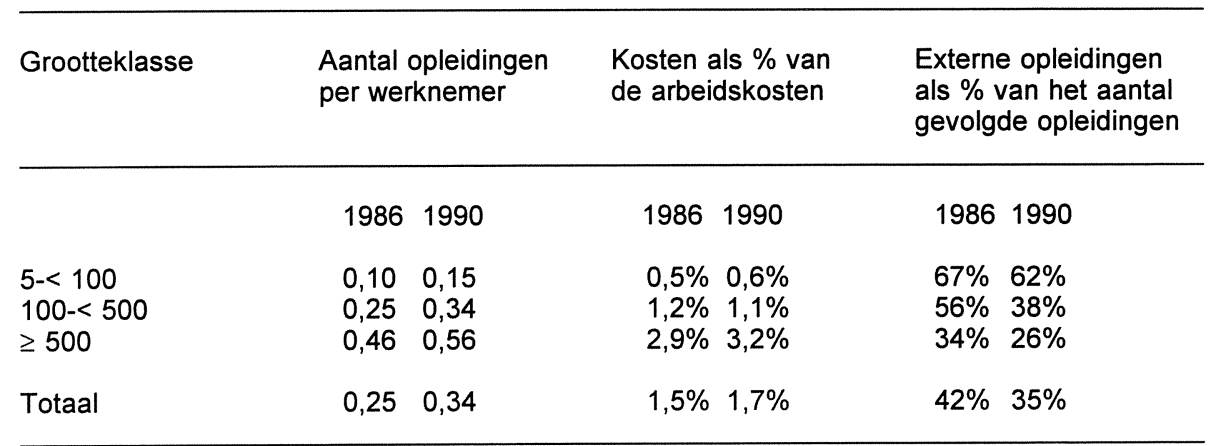

Bron: CBS, 1988b, op basis van tabellen 2, 6 en 9

Omdat het CBS-onderzoek van toepassing is op een aanzienlijk deel van de werkzame beroepsbevolking in Nederland ${ }^{1}$ zijn deze gegevens zeer belangrijk om een algeheel beeld van de trainingsinspanning van bedrijven te krijgen. Interessante vraagstukken omtrent training spelen zich echter voor een groot deel af bij de intrede van nieuwe arbeidskrachten op de arbeidsmarkt. Allereerst is het zo dat nieuwe trends of ontwikkelingen vooral zichtbaar worden bij nieuwe cohorten werknemers. Door de analyses van scholing te betrekken op de nieuwkomers op de arbeidsmarkt, dit zijn voornamelijk schoolverlaters maar natuurlijk ook migranten en herintredende vrouwen, plaatst men als het ware een vergrootglas op nieuwe ontwikkelingen, waardoor de dynamiek op de voorgrond komt. Ten tweede sluit training van nieuwkomers aan bij moderne 'human resource management'-vragen zoals: moet er, en zo ja in welke mate, geïnvesteerd worden in 'menselijk kapitaal' en is het dan rationeler te kiezen voor een hoog initieel opleidingsniveau plus

1. Dit CBS-onderzoek heeft overigens niet betrekking op de gehele Nederlandse beroepsbevolking. Zo worden bedrijven met minder dan 5 werknemers en de gehele overheidssector uitgesloten. Dit resulteert in een generaliseerbaar speciaal universum van 3,3 miljoen werknemers ten opzichte van een gehele populatie van 5,4 miljoen werknemers in 1990. 
beperkte additionele training, of kan daarentegen beter voor de variant gekozen worden waarin een beperkt initieel niveau wordt geworven in combinatie met ruime additionele training?

In zowel het RUBS-onderzoek (Registratie van de Uitstroom en Bestemming van Schoolverlaters) als de HBO-Monitor wordt de arbeidsmarktpositie van schoolverlaters in kaart gebracht (respectievelijk Van Smoorenburg e.a. 1994 en Van de Loo en Van der Velden, 1994). Op basis van beide onderzoeken is onder meer bekend in welke bedrijfsklasse men gaat werken, hoe groot de organisatie is waar men gaat werken, of men al dan niet een cursus of een opleiding in het kader van het leerlingwezen of in-service onderwijs volgt en welke initiële opleidingen men reeds heeft afgerond. In mei/juni 1993 hebben 26.700 gediplomeerde en ongediplomeerde schoolverlaters van het VBO, het KMBO, het $\mathrm{MBO}$ en het AVO gerespondeerd op de RUBS-vragenlijst en in het najaar van 1993 hebben ruim 14.000 gediplomeerde schoolverlaters gerespondeerd op de vragenlijst van de HBO-monitor. Beide bestanden zijn bij elkaar gevoegd en gewogen naar landelijke populatiegegevens. Een groot gedeelte van deze schoolverlaters gaat voltijds verder leren, maar er is toch ook een groot aantal schoolverlaters dat op het moment van enquête (ongeveer een jaar na afstuderen) tot de zogenaamde werkzame personen ${ }^{2}$ behoort. Dit levert in totaal bijna 17.000 cases op. In figuur 2.1 is voor deze groep schoolverlaters zowel het opleidingsniveau ${ }^{3}$ als het percentage training uitgezet tegen de organisatiegrootte. Onder 'training inclusief leerlingwezen' wordt het percentage van de op het moment van enquêteren werkzame personen verstaan, dat op dat moment een opleiding in het kader van het leerlingwezen/in-service onderwijs of een cursus of bedrijfsopleiding volgt, zijnde geen hobbycursus of een voltijds vervolgopleiding. Met deze indicator wordt rekening gehouden met een belangrijke geïnstitutionaliseerde vorm van training door organisaties, namelijk het leerlingwezen en het in-service onderwijs. In sommige gevallen is het echter wenselijk om het leerlingwezen/in-service onderwijs buiten te sluiten. In de grafiek is daarom ook de indicator 'training exclusief leerlingwezen' weergegeven, dat wil zeggen de op het moment van enquêteren werkzame personen dat op dat moment een cursus buiten het leerlingwezen of het in-service onderwijs volgt, zijnde geen hobbycursus of een voltijds vervolgopleiding.

Allereerst is in figuur 2.1 te zien dat er een U-vormig verband bestaat tussen

2. Het CBS verstaat onder 'werkzame personen' iedereen die 12 uur of meer per week betaald werk verricht. Diegenen die de militaire of vervangende dienstplicht vervullen worden niet tot de werkzame personen gerekend.

3. Het opleidingsniveau is bepaald door bij de gediplomeerden uit te gaan van de in het schooljaar 1991-1992 voltooide opleiding en bij de ongediplomeerden uit te gaan van de vooropleiding. 
organisatiegrootte en het percentage training (inclusief opleidingen in het kader van het leerlingwezen of het in-service onderwijs). De minste training vindt plaats bij de middelgrote bedrijven, namelijk bij bedrijven met 50 tot 100 werknemers. Het verschil tussen het minimale en het maximale percentage training is overigens niet zo erg groot. Dit U-vormig verband verandert in een monotoon stijgende lijn, zodra opleidingen in het kader van het leerlingwezen of het in-service onderwijs buiten de definitie van training worden gehouden. Hoe groter het bedrijf des te groter is het percentage werkzame schoolverlaters dat op dat moment een cursus volgt. Het verschil tussen beide grafieken toont aan dat in kleine bedrijven veelvuldig gebruik wordt gemaakt van training door middel van het leerlingwezen of het in-service onderwijs. Bovendien is in de figuur te zien dat het gemiddelde opleidingsniveau van de instroom van schoolverlaters stijgt naarmate organisaties groter zijn. Grotere organisaties trainen dus niet alleen meer, ze werven ook een gemiddeld hoger opleidingsniveau.

Figuur 2.1

Het gemiddelde opleidingsniveau van de instroom van schoolverlaters en het percentage training afgezet tegen de organisatiegrootte Opleidingsniveau $^{\text {a }}$

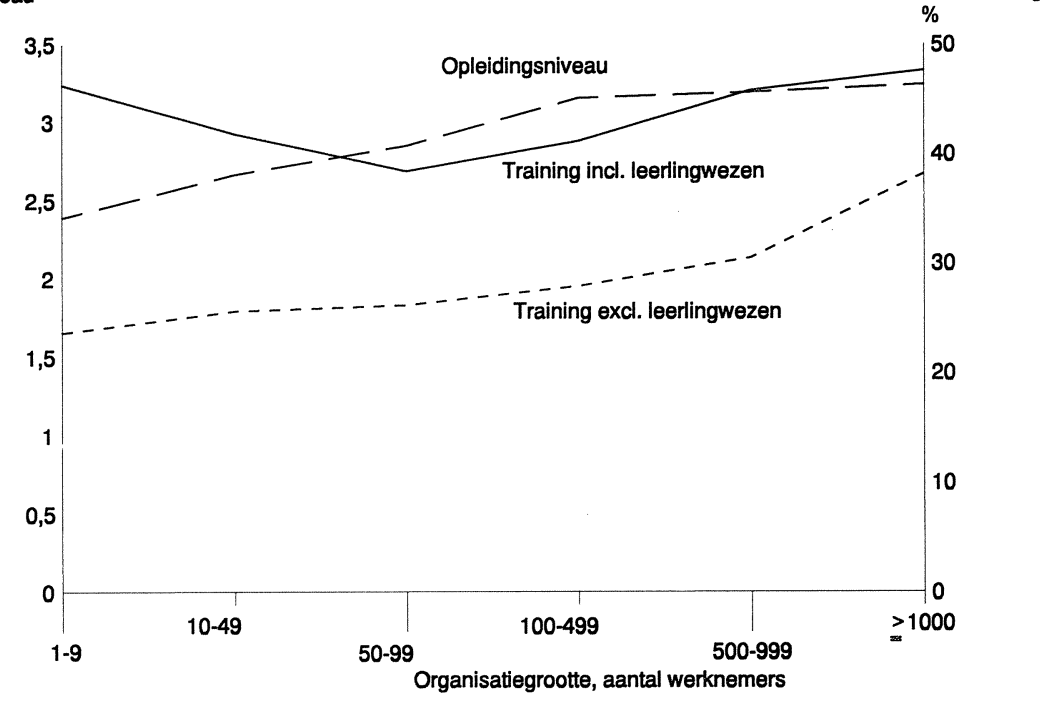

$$
\begin{array}{ll}
\text { a. }=\text { basisschool } & 2=\text { KMBO } \\
1=\text { VBO/MAVO } & 3=\text { MAVO/HAVO/NWO }
\end{array}
$$

Bron: ROA (RUBS'93 en HBO-Monitor 1993)

Zoals eerder gemeld, varieert de opleidingsinspanning van bedrijven zeer sterk naar bedrijfstakken c.q. bedrijfsklassen. Tabel 2.3 laat zien dat er in 1990 gemiddeld 
$f 900$ per werknemer werd uitgegeven aan bedrijfs- en externe opleidingen. Voor de bedrijfstak 'Landbouw en visserij' lag dit bedrag op slechts $f 200$ per werknemer, terwijl dit bedrag in de bedrijfstak 'Transport-, opslag- en communicatiebedrijven' op $f 1900$ per werknemer lag (CBS, 1992). Ook bij de opleidingsindicator 'kosten van bedrijfs- en externe opleidingen als percentage van de directe arbeidskosten' zijn de grote verschillen tussen bedrijfstakken goed waar te nemen. Zo lag in 1990 dit percentage bij de bedrijfstak 'Transport-, opslag- en communicatiebedrijven' op $3,4 \%$, terwijl bij de bedrijfstak 'Bouwnijverheid en -installatiebedrijven' het percentage op $0,5 \%$ lag. De andere bedrijfstakken bevinden zich tussen beide extremen. De bedrijfstakrangschikking is tussen 1986 en 1990 nauwelijks gewijzigd.

Tabel 2.3

Aantal opleidingen per werknemer, opleidingskosten per werknemer en opleidingskosten als percentage van de directe arbeidskosten naar SBI-bedrijfstak (1986 en 1990)

\begin{tabular}{|c|c|c|c|c|c|c|}
\hline \multirow[t]{2}{*}{ Bedrijfstak } & \multirow{2}{*}{\multicolumn{2}{|c|}{$\begin{array}{l}\text { aantal opleidingen } \\
\text { per werknemer } \\
19861990\end{array}$}} & \multicolumn{2}{|c|}{ kosten per werknemer } & \multicolumn{2}{|c|}{$\begin{array}{l}\text { kosten als } \% \mathrm{v} / \mathrm{d} \\
\text { directe arbeidskosten }\end{array}$} \\
\hline & & & 1986 & 1990 & 1986 & 1990 \\
\hline $\begin{array}{l}\text { Landbouw en visserij } \\
\text { Industrie, delfstoffen- }\end{array}$ & 0.04 & 0.12 & $f \quad 100$ & $f \quad 200$ & $0.2 \%$ & $0.6 \%$ \\
\hline $\begin{array}{l}\text { winning } \\
\text { Openbare nutsbedrijven }\end{array}$ & $\begin{array}{l}0.31 \\
0.32\end{array}$ & $\begin{array}{l}0.37 \\
0.40\end{array}$ & $\begin{array}{l}f 900 \\
f 1.100\end{array}$ & $\begin{array}{ll}f & 1.200 \\
f & 1.200\end{array}$ & $\begin{array}{l}1.6 \% \\
1.8 \%\end{array}$ & $\begin{array}{l}1.9 \% \\
1.9 \%\end{array}$ \\
\hline $\begin{array}{l}\text { Bouwnijverheid en instal- } \\
\text { latiebedrijven }\end{array}$ & 0.08 & 0.20 & $f \quad 200$ & $f \quad 300$ & $0.3 \%$ & $0.5 \%$ \\
\hline $\begin{array}{l}\text { Handel, horeca, restaurants } \\
\text { reparatiebedrijven }\end{array}$ & 0.13 & 0.27 & $f \quad 400$ & $f \quad 400$ & $0.8 \%$ & $1.1 \%$ \\
\hline $\begin{array}{l}\text { Transport, opslag- en } \\
\text { communicatiebedrijven }\end{array}$ & $n^{0.32}$ & 0.44 & $f 1.600$ & $f 1.900$ & $2.7 \%$ & $3.4 \%$ \\
\hline $\begin{array}{l}\text { Bank- en verzekeringswezen } \\
\text { comm. diensten } \\
\text { Overige dienstverlening }\end{array}$ & $\begin{array}{l}0.35 \\
0.21\end{array}$ & $\begin{array}{l}0.39 \\
0.33\end{array}$ & $\begin{array}{ll}f & 900 \\
f & 400\end{array}$ & $\begin{array}{ll}f & 900 \\
f & 600\end{array}$ & $\begin{array}{l}1.7 \% \\
0.7 \%\end{array}$ & $\begin{array}{l}1.7 \% \\
1.1 \%\end{array}$ \\
\hline Totaal & 0.25 & 0.34 & $f 800$ & $f \quad 900$ & $1.5 \%$ & $1.7 \%$ \\
\hline
\end{tabular}

Bron: CBS, 1992, tabel 2,3,9

Net als bij de trainingsgegevens naar organisatiegrootte kan ook bij de onderverdeling naar bedrijfsklasse worden gebruik gemaakt van het RUBS-bestand en het HBO-monitor bestand. In figuur 2.2 is voor de verschillende bedrijfsklassen het gemiddelde opleidingsniveau van de instroom uitgezet tegen het percentage (SBI) van het CBS; de gebruikte codes zijn in bijlage I te vinden. Onder 'percentage training' inclusief leerlingwezen wordt wederom verstaan, dat gedeelte van de op

4. Uitgesloten zijn bedrijven met minder dan 5 werknemers.

5. Uitgesloten zijn de SBI-bedrijfsklassen openbaar bestuur (90), religieuze organisaties (91), onderwijs (92), gezondheids- en veterinaire diensten (93) en maatschappelijke dienstverlening (94). 
het moment van enquêteren werkzame personen dat op dat moment een cursus (niet zijnde een hobbycursus of een voltijds vervolgopleiding), of een opleiding in het kader van het leerlingwezen of in-service onderwijs volgt. De figuur is op basis van het gemiddelde opleidingsniveau en het gemiddelde percentage training, over alle bedrijfsklassen heen gezien, ingedeeld in vier kwadranten.

\section{Figuur 2.2}

Het opleidingsniveau van de instroom van schoolverlaters afgezet tegen het percentage training voor de verschillende SBI-bedrijfsklassen

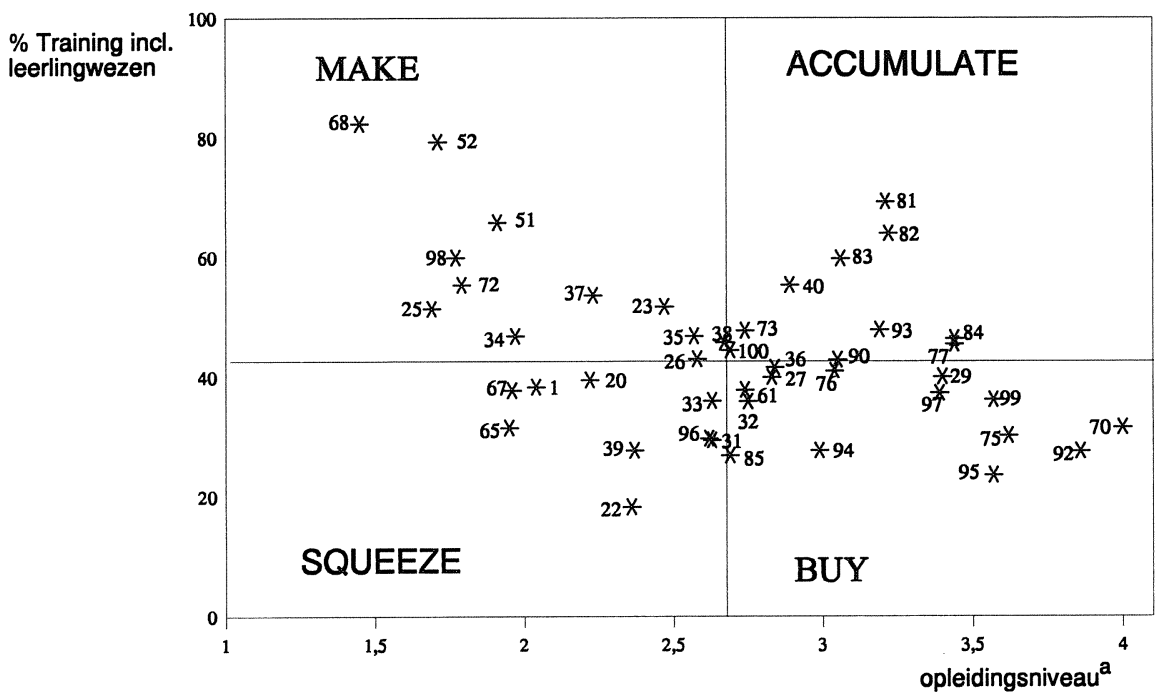

a zie noot a figuur 2.1

Bron: ROA (RUBS '93 en HBO-Monitor '93)

Er zijn bedrijfsklassen die een hoog opleidingsniveau werven en daarnaast ook nog eens fors trainen. Deze bedrijfsklassen accumuleren veel menselijk kapitaal ('ACCUMULATE'). Voorbeelden hiervan zijn de SBI-bedrijfsklassen 81 'Bankwezen', 82 'Verzekeringswezen' en 83 'Exploitatie van en handel in onroerende goederen'. Daarnaast zijn er ook bedrijfsklassen die een laag opleidingsniveau van schoolverlaters werven en ook nauwelijks training aanbieden ('SQUEEZE'). Zij exploiteren het aangeboden menselijke kapitaal en doen geen poging deze beperkte hoeveelheid menselijke kapitaal binnen het bedrijf of instelling te vergroten middels training. Voorbeelden hiervan zijn de SBI-bedrijfsklassen 65 'Detailhandel', 67 'Hotels, restaurants, cafés e.d.' en 22 'Textielindustrie'. Dan is er nog een kwadrant te onderscheiden waarin weliswaar een laag opleidingsniveau van schoolverlaters wordt aangetrokken, maar waarbij tevens fors wordt getraind. Deze bedrijfsklassen creëren zelf het nodige menselijke kapitaal ('MAKE'). Voorbeelden hiervan zijn de 
SBI-bedrijfsklassen 68 'Reparatiebedrijven voor gebruiksgoederen' (m.n. garagebedrijven), 52 'Bouwinstallatiebedrijven' en 51 'Bouwnijverheid'. Tot slot nog de omgekeerde situatie waarin een hoog initieel opleidingsniveau gecombineerd wordt met een beperkte hoeveelheid additionele training. Men koopt hier de benodigde hoeveelheid menselijk kapitaal gewoonweg op de externe arbeidsmarkt ('BUY'). Voorbeelden in dit kwadrant zijn de SBI-bedrijfsklassen 92 'Onderwijs en 95 'Sociaal-culturele en culturele instellingen'.

\section{Geslacht en opleidingsniveau}

Uit het CBS-onderzoek (CBS, 1992) met betrekking tot het onderzoeksjaar 1990 blijkt dat mannen gemiddeld 0,35 bedrijfs- of externe opleidingen volgen en dat vrouwen gemiddeld 0,30 bedrijfs- of externe opleidingen volgen. In het onderzoeksjaar 1986 was het verschil tussen mannen en vrouwen veel groter. In dat jaar volgden mannen gemiddeld 0,28 bedrijfs- of externe opleidingen en vrouwen gemiddeld 0,18 bedrijfs- of externe opleidingen. Het verschil in aantal gevolgde bedrijfs- en externe opleidingen tussen mannen en vrouwen is dus afgenomen. Deze afname kan te maken hebben met de toenemende participatiegraad van vrouwen op de arbeidsmarkt. Als werkgevers, onder de veronderstelling dat zij economisch rationeel handelen, verwachten dat vrouwen ten opzichte van mannen een hogere kans op verloop hebben dan zal er mutatis mutandis een prikkel zijn om minder in opleidingen van vrouwen te investeren, aangezien dan namelijk de verwachte terugverdienperiode bij vrouwen hoger is dan bij mannen. Een langdurige deelname van vrouwen aan het arbeidsleven kan deze verwachting doen bijstellen met als gevolg een grotere participatie van vrouwen aan scholing. Toch is in 1990 nog steeds het gemiddeld aantal bedrijfs- en externe opleidingen bij mannen hoger dan bij vrouwen. Dit blijkt overigens ook bij de in 1993 geënquêteerde schoolverlaters het geval te zijn (Van Smoorenburg e.a., 1994 en Van de Loo en Van der Velden, 1994). Het percentage training inclusief leerlingwezen en in-service onderwijs is bij mannen significant hoger dan bij vrouwen, namelijk $49 \%$ bij mannen en $38 \%$ bij vrouwen.

Het CBS-onderzoek bevat geen gegevens over de verdeling van bedrijfs- en externe opleidingen over de verschillende opleidingsniveaus. Wel kan hiervoor gebruik worden gemaakt van de OSA-onderzoeken. Uit het 'Trendrapport aanbod van arbeid' (Allaart e.a. 1991) blijkt dat het gemiddelde aantal cursussen per werknemer toeneemt naarmate het opleidingsniveau van de werknemer hoger is (tijdvak 1988-1990). In het 'Trendrapport vraag naar arbeid' (Allaart, Kunnen \& Van Stiphout, 1990) wordt geconcludeerd dat er een duidelijk verband is tussen het gemiddelde opleidingsniveau van het personeelsbestand en de scholingsgeneigdheid en scholingsinspanning van organisaties. Organisaties met hoog opgeleid personeel zijn zowel sterk scholingsgeneigd alsook scholingsintensief. Uit het 
gekoppelde RUBS/HBO-bestand blijkt eveneens dat het percentage training exclusief leerlingwezen en in-service onderwijs gestaag toeneemt, naarmate het opleidingsniveau van de werkzame schoolverlaters hoger is.

\section{Kans op training voor schoolverlaters}

Met de in de vorige paragrafen getrokken conclusies dat mannelijke schoolverlaters met een hoger initieel opleidingsniveau die werkzaam zijn in grotere organisaties en in bepaalde bedrijfstakken vaker getraind worden dan anderen, zijn we verder op zoek gegaan naar additionele verklaringen voor training. Wellicht dat ook de richting van de genoten opleiding ertoe doet. Zijn het bijvoorbeeld vooral diegenen met een technische opleiding die verder getraind worden? Misschien is het ook wel zo dat ook de leeftijd of de etniciteit verklarende grootheden zijn? Om dit te kunnen nagaan is een multivariate analyse uitgevoerd, waarbij zowel de eerder besproken als de hier genoemde aanvullende variabelen werden betrokken. Het voordeel van een multivariate aanpak is dat met alle variabelen tegelijk rekening kan worden gehouden. Er is een logistische regressievergelijking geschat, voor respectievelijk de kans op training inclusief opleidingen in het kader van het leerlingwezen en inservice opleidingen en voor de kans op training exclusief deze opleidingen. De regressieresultaten en een nadere technische toelichting zijn te vinden in bijlage II. In tabel 2.4 worden de resultaten op een kwalitatieve manier gepresenteerd waarbij alleen de significante resultaten zijn weergegeven.

De conclusie van de uitgevoerde analyse is dat zowel persoonskenmerken (geslacht, leeftijd), opleidingskenmerken (opleidingsniveau en opleidingssector) als organisatiekenmerken (organisatiegrootte, bedrijfsklasse) invloed hebben op de kans op training voor schoolverlaters. Het maakt voor sommige factoren overigens wel uit hoe training is geoperationaliseerd. Dit is vooral duidelijk bij het opleidingsniveau te herkennen. Zo komt het positieve verband tussen opleidingsniveau en de kans op training er uitsluitend uit als bij de definitie van training opleidingen in het kader van het leerlingwezen en in-service onderwijs niet worden meegeteld. Dit komt onder meer omdat VBO/MAVO-ers een grotere kans op training hebben dan MBO/HAVO/MWO-ers als het leerlingwezen/in-service onderwijs wel wordt meegeteld en hebben VBO/MAVO-ers een kleinere kans op training dan MBO/HAVO/WWO-ers indien het leerlingwezen/in-service onderwijs niet wordt meegeteld. Hiermee komt goed tot uitdrukking dat opleidingen in het kader van het leerlingwezen en in-service onderwijs gedeeltelijk tot het reguliere onderwijssysteem kunnen worden gerekend. 
Tabel 2.4

De kans op training voor werkzame schoolverlaters van het AVO, VBO, KMBO, MBO, HBO

\begin{tabular}{lll}
\hline Verklarende variabelen & $\begin{array}{l}\text { Kans op training } \\
\text { incl. leerlingwezen/ } \\
\text { in-service }\end{array}$ & $\begin{array}{l}\text { Kans op training } \\
\text { excl. leerlingwezen/ } \\
\text { in-service }\end{array}$ \\
\hline Persoonskenmerken & $\begin{array}{l}\text { Kleinere kans } \\
\text { Kleinere kans, die toeneemt } \\
\text { naarmate men ouder is }\end{array}$ & $\begin{array}{l}\text { Grotere kans, die afneemt } \\
\text { naarmate men ouder is }\end{array}$ \\
$\begin{array}{l}\text { Vuderen } \\
\text { nrouwen }\end{array}$ &
\end{tabular}

Opleiding

Basisschool e.d. (niv. 0)

VBO/MAVO (niv. 1)

KMBO (niv. 2)

MBO/HAVONWO (niv. 3)

HBO (niv. 4)

Techn. opl. sector

Econ. adm. opl. sector

Algemene opl. sector

Kleinere kans, die toeneem

naarmate men ouder is

Bedrijfsgrootte

Grotere kans
Referentie
Referentie

Kleinere kans

Kleinere kans

Kleinere kans

Referentie

Grotere kans

Referentie

Kleinere kans

Grotere kans

Kleinere kans

50-99 werknemers

100-499 werknemers

500-999 werknemers

$>1000$ werknemers

Bedrijfstak

Textielindustrie (22)

Elektrotechnische

industrie (36)

Bouwinstallatiebedrijven

Detailhandel (65)

Hotels, cafés,

restaurants, e.d. (67)

Reparatiebedrijven voor

gebruiksgoederen (68)

Zeevaart (73)

Luchtvaart (75)

Bankwezen (81)

Verzekeringswezen (82)

Onderwijs (92)

Gezondheids- en veterinaire

diensten (93)

Referentie
Grotere kans
Grotere kans
Grotere kans

Kleinere kans

Referentie

Grotere kans

Kleinere kans

Kleinere kans

Grotere kans

Kleinere kans

Kleinere kans

Grotere kans

Grotere kans

Maatschappelijke dienst-

verlening (94)

(Sociaal-)culturele

instellingen
Referentie

Grotere kans

Referentie

Kleinere kans

Kleinere kans

Kleinere kans

Grotere kans

Grotere kans

Kleinere kans

Kleinere kans

Kleinere kans

Kleinere kans

a alleen statistisch significante resultaten zijn weergegeven 
De effecten van de bedrijfsklasse op de kans op training verdwijnen niet als gecorrigeerd wordt voor organisatiegrootte, opleidingsniveau, opleidingssector, geslacht etc. en er zijn grote overeenkomsten te constateren met het in figuur 2.2 gepresenteerde scatterdiagram.

Reparatiebedrijven voor gebruiksgoederen, het bankwezen, de bouwinstallatiebedrijven en het verzekeringswezen bieden hogere kansen op training (inclusief leerlingwezen en in-service onderwijs). De luchtvaart, de zeevaart, de textielindustrie, de (sociaal-) culturele instellingen, de detailhandel en de horeca bieden daarentegen lagere kansen ${ }^{6}$. Reparatiebedrijven (met name garagebedrijven) en bouwinstallatiebedrijven maken relatief vaak gebruik van training door middel van het leerlingwezen en in-service onderwijs, want de significant hogere kans op training verdwijnt als training exclusief leerlingwezen en in-service onderwijs wordt genomen.

Bij een aantal overheidssectoren (bijvoorbeeld bedrijfsklassen 93 en 94) is ook iets dergelijks aan de hand. Als het leerlingwezen en in-service onderwijs wel meegeteld wordt dan is er (nog net) geen sprake van een significant lagere kans op training, maar als het leerlingwezen en in-service onderwijs niet meegeteld wordt dan blijken de verschillen wèl significant negatief te zijn. De genoemde overheidssectoren doen dus relatief veel aan training door middel van het leerlingwezen en in-service onderwijs. De bedrijfsklasse 95 '(sociaal-) culturele instellingen' heeft in beide gevallen een significant kleinere kans op training.

Uit figuur 2.1 bleek dat er een U-vormig verband bestaat tussen organisatiegrootte en training inclusief leerlingwezen/in-service onderwijs. Dit U-vormige verband is vooral toe te schrijven aan het leerlingwezen/in-service onderwijs, want middelgrote bedrijven of instellingen maken relatief weinig gebruik van dit soort training. Het werken in grote en vooral zeer grote organisaties (meer dan 1000 werknemers) vergroot de kans op het volgen van een cursus of bedrijfsopleiding. De onderlinge verschillen tussen de middelgrote en kleinere organisaties wat betreft de kans op het volgen van cursussen of bedrijfsopleidingen, zijn marginaal. Er kan gesteld worden dat:

- training door middel van het leerlingwezen/in-service onderwijs het laagst is bij middelgrote bedrijven of instellingen (van 50 tot 99 werknemers);

- training door middel van cursussen/bedrijfsopleidingen het hoogst is bij (zeer) grote bedrijven of instellingen;

6. Deze kansen moeten worden vergeleken met de elektrotechnische industrie (bedrijfsklasse 36) en zijn geordend naar grootte van het verschil. De elektrotechnische industrie wijkt niet veel af van de gemiddelde kans op training. 
- de totale training (cursussen/bedrijfsopleidingen plus leerlingwezen/in-service onderwijs) het hoogst is bij (zeer) grote bedrijven of instellingen en de verschillen tussen de kleinere categorieën marginaal zijn.

Er wordt wel gesteld dat het leerlingwezen en in-service onderwijs een dempend effect hebben op het positieve verband tussen organisatiegrootte en training. Het dempende effect zou maximaal zijn als er sprake zou zijn van een negatief verband tussen organisatiegrootte en de kans op training door middel van het leerlingwezen/in-service onderwijs. Dit verband blijkt echter niet negatief maar Uvormig te verlopen. Vandaar dat het leerlingwezen en het in-service onderwijs juist de verschillen in training tussen de (zeer) grote en middelgrote organisaties vergroot. Alleen bij de kleine en zeer kleine organisaties is er sprake van een licht, dempende werking door het fenomeen leerlingwezen en in-service onderwijs. Zonder leerlingwezen en in-service onderwijs zouden kleine organisaties immers relatief nog minder trainingsmogelijkheden bieden.

Tot slot blijken ook het geslacht (alleen bij training inclusief leerlingwezen en inservice onderwijs) en de leeftijd van de werkende schoolverlaters een significante rol te spelen. Daarentegen kan niet worden aangetoond dat de etniciteit van de werkende schoolverlaters de kans op training beïnvloedt. Met betrekking tot het geslacht blijkt dat vrouwelijke schoolverlaters een geringere kans hebben om getraind te worden. Dit is vooral te wijten aan het gegeven dat vrouwen minder vaak in het kader van het leerlingwezen werkzaam zijn. De effecten van leeftijd zijn vrij complex, het is namelijk zo dat:

- oudere schoolverlaters een grotere kans hebben om te worden getraind (exclusief leerlingwezen en in-service onderwijs), maar dat deze grotere kans iets afneemt naarmate men ouder is;

- oudere schoolverlaters een kleinere kans hebben om te worden getraind (inclusief leerlingwezen en in-service onderwijs), maar dat deze kleinere kans iets afneemt naarmate men ouder is.

De reden hiervan kan zijn dat het leerlingwezen als vorm van initieel onderwijs vooral voor jongeren bedoeld is en ouderen eerder langs andere weg worden (bij)geschoold. Aan deze leeftijdseffecten moet overigens niet teveel waarde worden gehecht, aangezien schoolverlatersonderzoek niet het meest ideale onderzoeksdesign is voor het toetsen van leeftijdseffecten op de kans op training.

\subsection{Samenvatting}

In Nederland is er sprake van een tamelijk geringe trainingsintensiteit van bedrijven, indien we dit vergelijken met enkele andere landen. Waarschijnlijk heeft dit deels te maken met het Nederlandse initiele onderwijssysteem dat zowel naar niveau als naar richting sterk gedifferentieerd is. Wel is het zo dat in Nederland tussen 1986 en 1990 de opleidingskosten als percentage van de directe arbeidskosten zijn 
gestegen, hetgeen vooral is toe te schrijven aan de forse stijging van het gemiddelde aantal opleidingen per werknemer.

De trainingsintensiteit van bedrijven hangt sterk samen met de omvang en het soort organisatie (geoperationaliseerd door middel van de bedrijfsklasse). De opleidingskosten als percentage van de directe arbeidskosten is in bedrijven met minimaal 500 werknemers bijvoorbeeld 5 à 6 keer zo hoog als in bedrijven met tussen de 5 en 100 werknemers. De verschillen naar bedrijfsgrootte zijn tussen 1986 en 1990 wel enigszins afgenomen. De grotere trainingsintensiteit van grotere bedrijven heeft gedeeltelijk te maken met het gemiddeld hogere opleidingsniveau van het personeelsbestand van grote bedrijven, maar er zijn meer verklaringen te geven (zie het volgende hoofdstuk). Verder is de trainingsintensiteit sterk afhankelijk van het soort organisatie. Uit zowel internationaal als nationaal onderzoek blijkt dat er sprake is van een grote spreiding van de trainingsindicatoren over de verschillende bedrijfsklassen. Sommige bedrijfstakken scoren in alle landen hoog (bijvoorbeeld de financiële sector) en sommige bedrijfstakken scoren in alle landen laag (bijvoorbeeld de textielsector). De trainingsintensiteit in een land wordt daarom sterk beïnvloed door de structuur van de werkgelegenheid in een land.

Hoger opgeleide personen worden meer getraind dan lager opgeleiden en mannen worden vaker getraind dan vrouwen. Het verwachte trainingsrendement is dus kennelijk bij hoger opgeleide personen respectievelijk mannen hoger. Dit zal bij het hogere opleidingsniveau te maken hebben met de steilere produktiviteitscurve en bij vrouwen met de kortere terugverdientijd.

Verder is nog in het bijzonder ingegaan op de training van schoolverlaters. Ook voor deze specifieke groep op de arbeidsmarkt geldt dat grotere organisaties gemiddeld een hoger opleidingsniveau werven en bovendien meer trainen.

De diverse bedrijfsklassen in Nederland konden verder worden ingedeeld in vier kwadranten: bedrijfsklassen die weinig trainen en een laag opleidingsniveau werven ('SQUEEZE'), bedrijfsklassen die veel trainen en een hoog opleidingsniveau werven ('ACCUMULATE'), bedrijfsklassen die niet trainen maar een hoog opleidingsniveau werven ('BUY') en bedrijfsklassen die een laag opleidingsniveau werven maar wel veel trainen ('MAKE'). Bovendien werd gevonden dat:

- voor met name de verklaring van de verschillen in opleidingsniveau het veel uitmaakt of het leerlingwezen en in-service onderwijs bij de definitie van training meegeteld wordt. Met name de VBO/MAVO-ers scoren dan veel hoger, uiteraard omdat zij de gebruikelijke instroom vormen voor het leerlingwezen als vorm van voortgezet initieel onderwijs. Als het leerlingwezen en in-service onderwijs niet meegeteld wordt dan neemt de kans op training toe naarmate het opleidingsniveau stijgt; 
- er wel wordt gesteld dat het leerlingwezen en in-service onderwijs een goede voorziening is om training toegankelijker te maken voor kleine organisaties, waardoor de trainingsverschillen met grote organisaties zouden afnemen. Deze constatering gaat niet op voor middelgrote organisaties (tussen de 50 en 99 werknemers), want de trainingsverschillen tussen middelgrote en (zeer) grote organisaties nemen door het leerlingwezen en in-service opleidingen alleen maar toe;

- er niet alleen grote verschillen zijn tussen de training in diverse bedrijfsklassen, maar dat er bovendien bedrijfsklassen zijn die relatief veel gebruik maken van het leerlingwezen en in-service onderwijs (reparatiebedrijven, bouwinstallatiebedrijven, handel in onroerende goederen). 
$\ldots \ldots$ 


\section{Training in de theorie}

\subsection{Inleiding}

Dit hoofdstuk gaat over het theoretisch perspectief van training door organisaties. Hierbij wordt training voornamelijk bezien vanuit het organisatie- of werkgeversbelang, ofschoon ook de percepties en verwachtingen van werknemers ter sprake zullen komen. Het gaat hierbij niet om bijvoorbeeld politieke of religieuze organisaties, maar om organisaties die als doel hebben het op economisch rendabele wijze voortbrengen van goederen of leveren van diensten. Voor zowel werkgevers als werknemers wordt in de theorievorming doorgaans een rationalistisch uitgangspunt gehanteerd. Werkgevers zullen kwalificaties (kennis, vaardigheden, inzichten en attitudes) van werknemers alleen "inkopen", op peil brengen of op peil houden, als voor hen de baten zullen opwegen tegen de kosten. Zij zullen bijvoorbeeld de verwachte hogere produktiviteit van het personeel afwegen tegen de leertijd, de cursusgelden, de gederfde produktiviteit etc. Voor werknemers geldt een soortgelijk rationalisme: zij zullen alleen voor training kiezen als de verwachte baten voor hun zullen opwegen tegen de te maken kosten. Een werknemer gaat bijvoorbeeld een bedrijfsopleiding volgen vanwege de verwachte inkomensontwikkeling, een beoogde positie, de te verkrijgen macht, status, of vanwege een 'intrinsieke motivatie', zoals ontwikkeling, vorming, bevrediging van leergierigheid. Deze baten worden door de werknemer afgewogen tegen de kosten, zoals de te leveren extra inspanning en de bijdrage in de opleidingskosten. Vaak zijn deze kosten en baten al op korte termijn te traceren, maar soms ook niet. Er is sprake van een investering in training indien gerichte uitgaven aan training worden gedaan, met het oog op in de toekomst te verwachten baten.

Bij dit in de theorievorming veelal gekozen rationalistische uitgangspunt dient een drietal kanttekeningen geplaatst te worden. Op de eerste plaats is in de genoemde voorbeelden reeds duidelijk geworden dat rationaliteit een breed scala van elementen kan bevatten: materiële en immateriële, meetbare en onmeetbare, psychologische en economische elementen. Op de tweede plaats kunnen er tijdelijke oneffenheden en informatiegebreken bestaan. Dit sluit aan bij Simon (1957), die het volgende stelt met betrekking tot het besluitvormingsgedrag van individuen: 'human behavior is intendendly rational, but only limitedly so'. Met andere woorden, ofschoon de doelstelling van individuen gericht is op rationaliteit, zal deze rationaliteit de facto niet bereikt worden, vanwege allerlei beperkingen bij het verwerken van informatie. Simon (1985) spreekt zelfs van de 'boundedly rational Homo Psychologicus of cognitive psychology [in stead of] the nearly omniscient Homo Economicus of rational choice theory'. Op de derde plaats zullen transacties tussen rationele werkgevers en rationele werknemers feitelijk beperkt worden door de 
bestaande constitutie van collectieve machtsverhoudingen. Op macro- en mesoniveau heerst er een regime van arbeidsverhoudingen tussen enerzijds werknemersorganisaties en anderzijds individuele werkgevers of werkgeversorganisaties. Dit institutionele regime krijgt zijn neerslag in onder andere collectieve arbeidsovereenkomsten, waaraan werkgevers en werknemers gebonden zijn. Met andere woorden, het gehanteerde rationalistische uitgangspunt bij kosten en baten van training moet ruim worden geïnterpreteerd (psychologische en economische elementen) en wordt tegelijkertijd de facto beperkt door cognitieve en sociaal-maatschappelijke grenzen.

De opmerking aan het begin van dit hoofstuk over het werkgevers- versus het werknemersbelang dient ook enigszins te worden toegelicht. Uitgangspunt van het zogenaamde politieke of arenamodel is het gegeven dat verschillende bij de besluitvorming in organisaties betrokken partijen vaak uiteenlopende belangen hebben (Koopman \& Pool, 1990). Het onderhandelingsspel tussen werknemer en werkgever kan dan als een 'zero-sum-game' worden opgevat, waarbij het gewin voor de één volledig ten koste gaat van het gewin bij de ander. Een voorbeeld hiervan is het loon: het vormt voor de werkgever een kostenpost, terwijl het voor de werknemer een inkomstenbron is. Een toename van de baten (inkomen) bij de werknemer gaat gepaard met een net zo grote toename van de kosten bij de werkgever (loonkosten). Er zijn echter ook transacties tussen werkgever en werknemer mogelijk, waarbij het nut van de één verhoogd kan worden zonder dat dit ten koste gaat van het nut van de ander (Pareto-optimaliteit). Hierdoor ontstaan tussen werkgever en werknemer vormen van 'samenwerking' in plaats van vormen van 'vechten'. Een goed voorbeeld hierbij is 'training', aangezien dit positieve opbrengsten kan genereren voor zowel werkgevers (hogere produktiviteit) als werknemers (hogere beloning).

Uitgaande van het bovenstaande gaan we nu op een tweetal manieren naar training in bedrijven kijken. Allereerst van buitenaf (paragraaf 3.2) en daarna van binnenuit (paragraaf 3.2). Organisaties zijn tot op zekere hoogte de resultante van omgevingsontwikkelingen, maar kennen ook hun eigen, economische wetmatigheden. Het hoofdstuk wordt in paragraaf 3.4 afgesloten met enkele samenvattende conclusies.

\subsection{Training van buitenaf gezien}

Het in figuur 3.1 weergegeven model bevat de meest dominante invloedssferen voor een organisatie, voor wat betreft de afstemming in een organisatie tussen enerzijds de vereiste kwalificaties en anderzijds de beschikbare kwalificaties. Natuurlijk is een model nooit volledig, omdat het nu eenmaal een vereenvoudiging is van de werkelijkheid. De pijlen in het schema duiden op de belangrijkste relaties 
tussen de variabelen, die in het vervolg van deze paragraaf zullen worden toegelicht.

Figuur 3.1

Het afstemmingsmodel

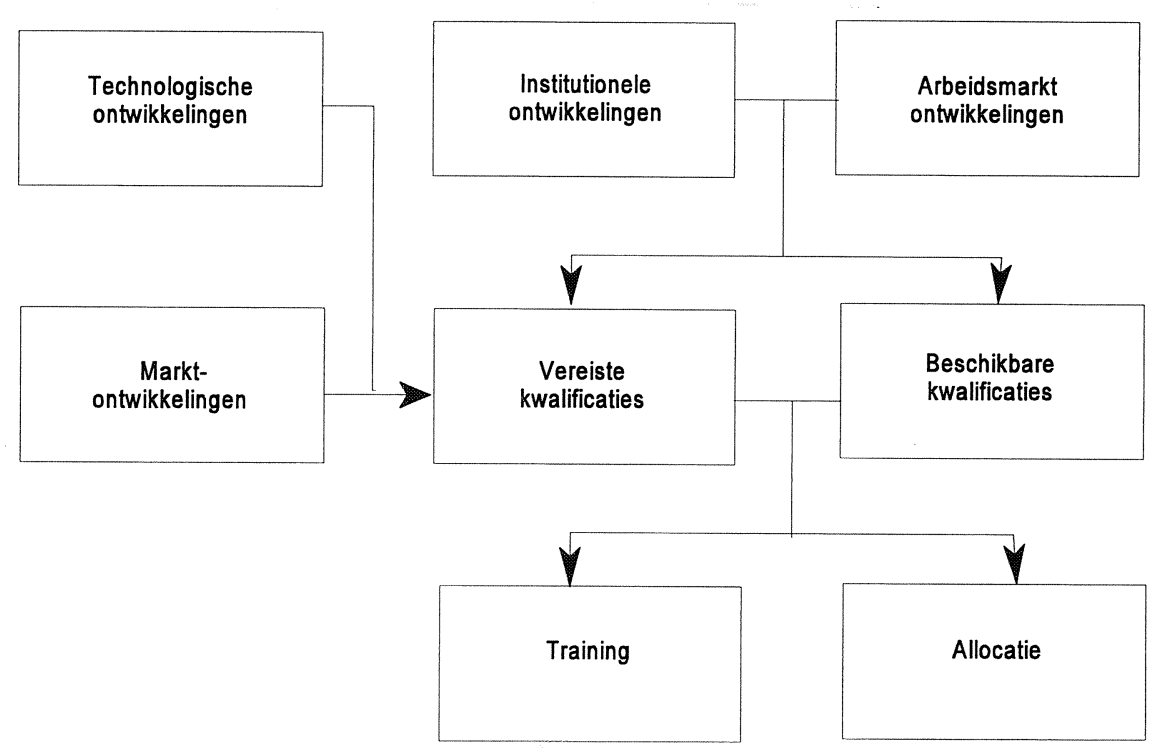

Technologische en marktontwikkelingen hebben invloed op de hoeveelheid en het type vereiste kwalificaties (=menselijk kapitaal). Verder zijn institutionele en arbeidsmarktontwikkelingen van belang. Zij zijn bepalend voor zowel de vereiste kwalificaties als ook de beschikbare kwalificaties. Er kan op verschillende manieren worden omgegaan met een eventuele discrepantie tussen vereiste en beschikbare kwalificaties. Zowel allocatie (inkopen gewenste kwalificaties, afstoten ongewenste kwalificaties) als training van het zittende personeel kan een oplossing bieden.

\section{Technologische ontwikkelingen}

De technologisering en informatisering van produktieprocessen schrijden voort. De ontwikkelingen in het aanbod van produktiemiddelen gaan snel en producenten schaffen de nieuwste machines en informatieverwerkende apparatuur aan. Te denken valt aan machines met korte in- en omsteltijden, gericht op kleinere series produkten, of algemener 'flexibele produktie-automatisering' (De Sitter, 1987) en computertechnologieën zoals Computer Aided Design (CAD), Computer Aided Manufacturing (CAM), robotisering, kantoorautomatisering, telewerk en telecommunicatie. 
Welke gevolgen hebben deze technologische ontwikkelingen nu voor het vereiste kwalificatieniveau? We zien dat het algemene opleidingsniveau van de beroepsbevolking de laatste decennia sterk is gestegen. Enerzijds kan dit het gevolg zijn van verandering van de functie- of beroepenstructuur, waarbij hoger geschoolde beroepen frequenter en lager geschoolde beroepen juist minder frequent voorkomen. Dit wordt wel het structuureffect genoemd (De Grip, 1987a). Anderzijds kunnen binnen een functie hogere opleidingseisen wordt gesteld. Aan de hogere opleidingseisen binnen een functie kunnen twee verklaringen ten grondslag liggen. Op de eerste plaats kan het vereiste opleidingsniveau binnen een functie stijgen doordat werkgevers inspelen op een toename van het beschikbare opleidingsniveau op de arbeidsmarkt. Dit wordt in de literatuur neerwaartse verdringing genoemd (Van Hoof \& Dronkers, 1980). Op de tweede plaats kan het vereiste opleidingsniveau binnen een functie stijgen, vanwege een door technologische en organisatorische veranderingen ingegeven feitelijke 'upgrading' van de werkzaamheden. Eenvoudige, routinematige taken zullen daarbij steeds meer worden overgenomen door machines, waardoor hoger gekwalificeerde functies ontstaan (bijvoorbeeld Van Hoof \& Huiskamp, 1984). Zo blijkt uit verricht empirisch onderzoek dat fysiek kapitaal en ongeschoold arbeid elkaars substituut vormen en dat fysiek kapitaal en hooggeschoold menselijk kapitaal complementen zijn (Broer en Janssen, 1989 en Hartog \& Theeuwes, 1990). Overigens zijn er in specifieke omstandigheden ook aanwijzingen voor 'downgrading' van werkzaamheden binnen een functie. Nieuwe taken als gevolg van technologische ontwikkelingen verrijken het werk dan niet, maar verarmen het juist (intensivering, minder autonomie etc.). Nieuwe technologie leidt aldus niet altijd tot rekwalificatie van functies (Pot, 1985).

Bovendien zijn er aanwijzingen dat technologische ontwikkelingen gevolgen hebben voor het type kwalificatievereisten. Hövels, Esch \& Van den Berg (1988) laten in hun onderzoek zien dat de werkzaamheden van HTS-ingenieurs een set van algemene vaardigheden vereist zoals probleemoplossend vermogen, flexibiliteit, communicatiemogelijkheden e.d. Uit een studie van Muysken et al. (1990) in een viertal sectoren, te weten het bankwezen, de bouw, de chemische \& rubber industrie en de hout \& constructiematerialen industrie, komt naar voren dat meer algemene en minder specifieke kwalificaties zijn vereist. Algemene vaardigheden zoals leervermogen, flexibiliteit en het vermogen verantwoordelijkheid te dragen, nemen als gevolg van de technologische ontwikkelingen in belang toe.

Bij bovengenoemde beschrijving van de gevolgen van technologische ontwikkelingen voor het kwalificatieniveau van de werkgelegenheid dienen twee kanttekeningen te worden geplaatst. Allereerst lijkt het erop dat het 'technologisch determinisme' een alomvattende rol speelt bij de verklaring van kwalificatie-eisen. $\mathrm{Er}$ zijn echter ook andere ontwikkelingen en factoren die het niveau en het type kwalificatievereisten bepalen. Hiervoor wordt verwezen naar de volgende paragrafen. 
Bovendien moet nog een tweede kanttekening worden gemaakt. Technologische ontwikkelingen kunnen worden gezien als 'technological trajectories' (Dosi, 1983), waarbij zich voor produktietechnieken en produktiemethoden die gestoeld zijn op dezelfde technologische basis of eenzelfde basisinnovatie (bijvoorbeeld de stoommachine, de chip) evolutionaire processen afspelen, waarin op bestaande technieken voortdurend verbeteringen worden aangebracht en waarin men steeds efficiënter leert omgaan met gegeven technische mogelijkheden (Diederen, et al., 1988). Over de gehele economie bezien vindt diffusie van technologische innovaties over bedrijven plaats, waardoor organisaties zich in een verschillend stadium van ontwikkeling bevinden. Op het niveau van bedrijven zijn ook verschillende stadia te onderscheiden. Een technologische innovatie is voor een arbeidsorganisatie vaak een project dat een aantal fases doorloopt, waarbij de volgende fases kunnen worden onderscheiden: een voorbereidende fase, een implementatiefase, een rijpheidsfase en een afstervingsfase. De verwachting is dat er in de voorbereidende en in de implementatiefase van een technologische innovatie grote behoefte zal zijn aan hooggeschoold onderzoeks- en ontwikkelingspersoneel. In de implementatiefase zal bovendien de behoefte aan gekwalificeerd produktiepersoneel groter zijn, aangezien zij moeten leren omgaan met de innovatie. Naarmate een techniek een zekere rijpheidsfase heeft bereikt, zal de behoefte aan hooggeschoold onderzoeks- en ontwikkelingspersoneel afnemen (Diederen, et al. 1988). Langzamerhand raakt de organisatie bekend met alle mogelijkheden die een techniek biedt en zal het vereiste kwalificatieniveau van zowel het onderzoeks- \& ontwikkelingspersoneel als het produktiepersoneel niet meer stijgen of zelfs dalen. Sterk innoverende bedrijven zullen dan inmiddels weer een nieuw project onder handen hebben genomen.

\section{Marktontwikkelingen}

Afzetmarkten raken steeds verder gedifferentieerd en zijn veeleisender geworden. Levensduur, gebruikskosten, garantievoorwaarden en service werden in de jaren zestig en zeventig steeds meer betrokken bij de afwegingen van de consument. Bovendien verschoven in de jaren tachtig veel markten van een 'sellers'- naar een 'buyers'-markt, waardoor producenten sneller met nieuwe typen moesten komen, meer varianten ontwikkelen en meer maatwerk leveren met een kortere levertijd (Van Amelsvoort \& Buyse, 1991). Bovendien neemt de rol van de dienstverlenende sector in de economie toe. Bij de levering van diensten is kwaliteit en flexibiliteit vaak van wezenlijk belang. De prijs alleen is geen 'sufficient statistic' meer. Kortom, de prijs, de kwaliteit en de flexibiliteit zijn alle drie belangrijke performance-criteria geworden (Kumpe, Bolwijn \& Goudswaard, 1985).

Dit proces wordt versterkt door de toenemende concurrentie als gevolg van de internationale vervlechting van economieën en bedrijven. In het bijzonder de 
eenwording van Europa zal gevolgen hebben voor de internationale concurrentiepositie van ondernemingen. 'Concurrentie van lage-lonenlanden, het wegvallen van de Europese grenzen en de toenemende overcapaciteit, maken de concurrentiestrijd feller. Door het afstoten van de voortbrenging van eenvoudige produkten met weinig toegevoegde waarde naar lage-lonenlanden kan concentratie plaatsvinden op hoogwaardige produkten en produktiewijzen (Van Amelsvoort \& Buyse, 1991). Daar staat overigens tegenover dat de Europese eenwording gemeenschappelijke buitengrenzen met zich meebrengt, die de nodige buffers opwerpen tegen de concurrentie van de lage-lonenlanden. Toch is de verwachting dat Nederland zich in toenemende mate zal richten op het genereren van hoogwaardige produkten, processen en diensten, waarbij (de transformatie) van kennis steeds centraler komt te staan en een voortdurende gerichtheid op aanpassing en vernieuwing noodzakelijk is.

Hierbij wordt van de veronderstelling uitgegaan dat een toenemend kwaliteits- en flexibiliteitsbesef gepaard gaat met een toename van het vereiste kwalificatieniveau van het personeel. Als gevolg van hogere kwaliteitsstandaarden van de output van organisaties (goederen, diensten), zullen ook de kwaliteitseisen van de input (grondstoffen, personeel) en van de throughput (produktieprocessen, arbeidsprestaties) hoger moeten zijn. Denk hierbij bijvoorbeeld aan de opkomst van ISOkwaliteitsnormen, kwaliteitscircels, klantvriendelijkheid etc. Organisaties zullen bovendien flexibeler in de markt dienen te staan. Zij zullen dan meer produktvarianten te bieden hebben, deze produkten zullen in het algemeen een kortere produktlevenscyclus hebben, er vindt bovendien meer innovatie plaats en er wordt Just-In-Time geproduceerd. Kortom, het externe flexibiliteitscriterium heeft tevens interne implicaties. De te verrichten arbeid zal sneller veranderen, waardoor het adaptatievermogen van zowel de organisatie in zijn totaliteit als van de individuele werknemers groter zal moeten zijn. Dit leidt tot multi-inzetbaarheid en verticale en horizontale mobiliteit. De verwachting is dat dit zal leiden tot een toenemende behoefte aan meer algemene, zowel cognitieve als sociale, kwalificaties van het personeel.

Institutionele ontwikkelingen

Met de institutionele ontwikkeling wordt het veranderende complex van waarden, normen, gewoonten, regels, overeenkomsten en wetten bedoeld, dat voor een arbeidsorganisatie op een bepaalde tijd en plaats als gegeven kan worden beschouwd. In het kader van deze notitie worden drie institutionele factoren behandeld die van invloed zijn op de vereiste en de beschikbare kwalificaties.

Instituties spelen altijd een rol bij de totstandkoming van beschikbare en vereiste kwalificaties. In de huidige Westerse maatschappij is het bijvoorbeeld 'bon ton' om 
hoger initieel onderwijs te voltooien, extra bedrijfscursussen te volgen en kwalificaties op het werk te ontwikkelen. Bovendien worden beschikbare kwalificaties gekanaliseerd aangeboden via een gedifferentieerd stelsel van onderwijstypen, waarbij wordt ingespeeld op collectief geformuleerde behoeften op het niveau van vakdeelmarkten en beroepsverenigingen (bijvoorbeeld het Nederlands Instituut van Psychologen). Kwalificaties zijn dan niet alleen gekoppeld aan mensen, maar ook aan categorieën van mensen. Aldus zijn instituties om diverse redenen van belang voor de beschikbaarheid van kwalificaties. Maar, ook vereiste kwalificaties worden door een institutioneel kader omgeven. Bij de vaststelling van de vereiste kwalificaties zal een toetsing plaatsvinden aan de hand van gewoonten, regels, overeenkomsten, wetten e.d. Zo kan het bijvoorbeeld 'common-sense' danwel verplicht zijn (bijvoorbeeld in een C.A.O.) om bij een bepaalde functie, werkinhoud of opdracht een bepaald kwalificatieniveau als 'vereist' aan te merken. Kortom, de totstandkoming van vereiste en beschikbare kwalificaties en ook de afstemming tussen beide is vaak een op voorhand gereguleerd of impliciet, door normen en gewoonten gestuurd, proces.

Een hierboven reeds genoemde institutionele factor, die invloed heeft op de beschikbaarheid van kwalificaties, is het onderwijssysteem. Het reguliere onderwijs, maar ook het niet-reguliere onderwijs produceren kwalificaties. Het reguliere onderwijssysteem kan echter bij schoolverlaters kwalificaties produceren, die onvoldoende aansluiten bij de eisen die in het latere beroepsleven worden gesteld. Dit kan natuurlijk ook het geval zijn bij het niet-reguliere onderwijs (bijvoorbeeld bedrijfs- en externe opleidingen), maar de verwachting is toch dat bedrijfs- en externe opleidingen het reguliere onderwijs aanvullen, daar waar dit laatste tekortschiet. Het nietreguliere onderwijs is door zijn gevarieerde aanbod van opleidingen aan het reeds werkzame deel van de beroepsbevolking beter in staat om in te spelen op onzekere ontwikkelingen tijdens het beroepsleven en in te gaan op de specifieke wensen van organisaties en om daarbij maatwerk in kwalificaties te leveren.

Tot slot wordt een derde institutionele factor genoemd, namelijk de kwalificatiefaciliteiten die overheid en sociale partners bieden. Deze faciliteiten kunnen in geld uitgedrukt worden (subsidies, belastingaftrek), maar kunnen ook betrekking hebben op de sociaal-juridische infrastructuur (studieverlofregelingen, kaderwet volwasseneneducatie, leerlingwezen etc.).

\section{Arbeidsmarktontwikkelingen}

Het spel tussen vraag en aanbod op de arbeidsmarkt levert niet altijd een evenwichtssituatie op. De arbeidsmarkt kan ruim of krap zijn, waardoor er overschotten (werkloosheid) en tekorten (onvervulbare vacatures) kunnen bestaan. Aangezien arbeid niet homogeen en volledig uitwisselbaar is, kunnen er tegelijkertijd tekorten 
en overschotten op verschillende 'arbeidsdeelmarkten' zijn. Naast deze open discrepanties bestaan er aanwijzingen voor het bestaan van verborgen discrepanties tussen de vraag naar en het aanbod van arbeidskrachten. Het gemiddelde opleidingsniveau van de Nederlandse werknemers is in de laatste 30 jaar gestegen ('upleveling'). Het feitelijke functieniveau is in de periode 1960-1985 ook toegenomen, maar niet in voldoende mate om de stijging van het opleidingsniveau te compenseren. Er kan dus gesproken worden van toenemende onderbenutting en verslechterde kansenstructuren (Huijgen, 1989).

Het ROA voorspelt voor de periode tot 1998 , dat bij de top tien van opleidingen met de hoogste relatieve uitbreidingsvraag er zes WO-opleidingen en drie HBOopleidingen in vertegenwoordigd zullen zijn. Bij de top tien van opleidingen met de laagste (soms negatieve) relatieve uitbreidingsvraag tot 1998 zijn daarentegen het basisonderwijs, het MAVO en vijf VBO-opleidingen vertegenwoordigd (ROA, 1993). Ofschoon er verschillen in opleidingsrichtingen zijn aan te geven, kan in zijn algemeenheid toch gezegd worden, dat de uitbreidingvraag op de arbeidsmarkt geconcentreerd is bij de hoger opgeleiden en dat bij de lager opgeleiden de uitbreidingsvraag juist negatief is.

Voor werkgevers is de richting en het niveau van de kwalificaties een belangrijk selectiecriterium omdat zij een voorname voorspeller vormen van de toekomstige produktiviteit. Vandaar dat de "voorraad" kwalificaties op de externe arbeidsmarkt, en het gemak waarmee deze kwalificaties te verkrijgen zijn, van reële invloed zijn op de afstemmingsbeslissing van werkgevers. In een ruime arbeidsmarktsituatie zullen werkgevers geneigd zijn om voor 'allocatie' te kiezen. De werkgever kan namelijk personeel kiezen met kwalificaties die precies in de specifieke behoefte voorzien (optimale matching). Bovendien kost training tijd. We zullen verderop nog zien dat bij de keuze tussen allocatie of training inderdaad met de transactiekosten rekening moet worden gehouden. In een krappe arbeidsmarktsituatie zal daarentegen sneller of vaker voor training worden gekozen. Op deze manier is de organisatie niet of minder afhankelijk van het beperkte, externe aanbod van kwalificaties.

De Nederlandse beroepsbevolking ontgroent en vergrijst. Dit houdt in, dat er een relatieve en absolute daling van het aantal jonge werknemers valt waar te nemen en eveneens een relatieve en absolute stijging van de hoeveelheid oudere werknemers (Allaart, 1991). Aangezien ook de kwalificaties zelf kunnen verouderen door slijtage, economische veroudering en atrofie (slijtage van kennis door verwaarlozing), ontstaat er door de veroudering van de beroepsbevolking een versterkte neerwaartse druk op de hoeveelheid beschikbare kwalificaties (zie ook De Grip, Groot, Heijke \& Willems, 1990). Dit wordt voor een groot gedeelte gecompenseerd door het stijgende opleidingsniveau van nieuwkomers (schoolverlaters, herintre- 
dende vrouwen) op de arbeidsmarkt. Als dit niet volstaat zullen ouderen bij-, om-, of hergeschoold moeten worden.

\section{Afstemming}

De 'goodness of fit' met de omgeving zal de effectiviteit van een organisatie bepalen. Dit stellen althans de aanhangers van de contingentie-benadering. Bij de organisatie-omgeving kunnen we denken aan technologische ontwikkelingen, marktontwikkelingen, institutionele ontwikkelingen en ook ontwikkelingen in de arbeidsverhoudingen of op de arbeidsmarkt. Mintzberg is met zijn Structure in Fives (1983) de meest bekende aanhanger van de contingentiebenadering. 'De contingentiebenadering wordt in het algemeen aangeduid als de denkrichting, die zich richt op relaties tussen organisatie en omgeving. De organisatie wordt daarbij beschouwd als een open systeem, waarin de relaties tussen de elementen waaruit het systeem is opgebouwd mede bepaald worden door de relevante omgeving. De relevante omgeving bestaat uit elementen waarmee grenstransacties plaatsvinden' (Ahaus \& Kastelein, 1985). Aanhangers van de contingentiebenadering nemen aan dat een systeem alleen effectief kan functioneren als er sprake is van een zeker evenwicht tussen organisatie en relevante omgeving. Dat evenwicht komt tot uitdrukking in de samenstelling en de eigenschappen van enerzijds de organisatie en anderzijds de relevante omgeving.

Vanuit de populatie-ecologische theorie (of natuurlijke-selectievisie) wordt de contingentiebenadering bekritiseerd met de stelling dat het adaptatievermogen van een individuele organisatie gering is en dat de adaptatie aan de veranderende omgeving juist plaatsvindt door het afsterven, bijvoorbeeld door faillissement, van niet-aangepaste organisaties of door het ontstaan van nieuwe gemuteerde organisaties (Aldrich, Howard \& Pfeffer, 1976; Freeman \& Hannan, 1977). Zowel de contingentiebenadering als de populatie-ecologische theorie stellen echter de relatie tussen omgeving en organisatie centraal en komen voort uit een systeemtheoretisch concept.

De vereiste en de beschikbare hoeveelheid en soort kwalificaties binnen een organisatie staan in voortdurende interactie met hun omgeving. Vandaar dat technologische, markt-, institutionele en arbeidsmarktontwikkelingen invloed hebben op de vereiste en beschikbare kwalificaties. Als er een discrepantie bestaat tussen de vereiste en de beschikbare kwalificaties, heeft een onderneming of een overheidsinstelling in principe een aantal mogelijkheden. De eerste mogelijkheid is het probleem her- of wegdefiniëren en de discrepantie laten bestaan. Bij ondernemingen staat dan echter (op de lange duur) de behaalde winst of de continuïteit op het spel (zie ook de inleiding). Normaliter zal een onderneming en vaak ook een overheidsinstelling kiezen voor de tweede mogelijkheid: het probleem oplossen. De 
meest voor de hand liggende oplossingen zijn hierbij allocatie of training. Hiervoor wordt verwezen naar de volgende paragraaf.

Er kan ook voor een 'halve' oplossing worden gekozen, door namelijk een te hoog of een te laag kwalificatieniveau te kiezen en daardoor de feitelijke discrepantie gedeeltelijk te laten bestaan. Bij de paragraaf over technologische ontwikkelingen hebben we reeds het bestaan van neerwaartse en opwaartse verdringing gezien. Als gevolg van een ruime arbeidsmarktsituatie kunnen organisaties namelijk voor een te hoog kwalificatieniveau kiezen, wat leidt tot neerwaartse verdringing en onderbenutting. In een krappe arbeidsmarktsituatie kan een organisatie ook voor een te laag kwalificatieniveau kiezen, wat leidt tot opwaartse verdringing en overbenutting. Dit lijkt op het eerste gezicht irrationeel, omdat 'mismatch' altijd kosten met zich meebrengt. Toch zijn er aanwijzingen dat vooral onderbenutting stelselmatig voorkomt, zeker als dit toegang tot een zogenaamde interne arbeidsmarkt kan verschaffen (De Grip, Groot, Heijke \& Willems 1990). Misschien dat stelselmatige onderbenutting bij nieuwkomers in een interne arbeidsmarkt is te verklaren uit de wenselijkheid van eerst een 'proeve van bekwaamheid' te laten afleggen door de nieuwe rekruten. Overscholing leidt wellicht ook tot een besparing op de trainingskosten.

Ook door anders op de omgeving te reageren kan de discrepantie tussen vereiste en beschikbare kwalificaties worden opgelost. In het conceptuele model blijkt dat marktontwikkelingen, technologische ontwikkelingen, arbeidsmarktontwikkelingen en institutionele ontwikkelingen allen kunnen bijdragen aan het ontstaan van discrepanties. Aangezien een model een vereenvoudiging van de werkelijkheid is, zijn in figuur 3.1 vanwege de overzichtelijkheid niet alle mogelijke pijlen getekend, maar slechts de belangrijkste. Dit neemt niet weg dat een organisatie de 'determinanten' van de vereiste en beschikbare kwalificaties kan proberen te beïnvloeden. Een organisatie hoeft dus niet per se onmiddellijk een keuze te maken tussen allocatie of training, maar kan ook de ontwikkelingen zèlf beïnvloeden. We zullen hiervan enkele voorbeelden geven. Een bedrijf kan besluiten niet te kiezen voor een bepaalde produktmarktcombinatie waarvoor een hoog kwaliteitsniveau van het personeel is vereist, omdat het daaruit volgende discrepantieprobleem niet kan worden opgelost. Als tweede voorbeeld noemen we de organisatie die een C.A.O wil aanpassen om meer vrijheid te hebben in het oplossen van kwalificatieproblemen, bijvoorbeeld door middel van afspraken over outplacement. Kortom, er is een mogelijkheid tot beïnvloeding van de determinanten van de vereiste en de beschikbare kwalificaties. Het is dan ook niet vreemd dat er in de praktijk van management \& organisatie veel belangstelling bestaat voor concepten zoals: 'de manager als veranderaar', 'transformatiemanagement' of 'herontwerp van organisaties'. Ten onrechte hebben contingentie-onderzoekers een reactieve, passieve en actieloze karikatuur van de organisatie gemaakt (Child, 1972). 
Bij de afstemming tussen de vereiste en de beschikbare kwalificaties kan nog het volgende onderscheid worden gemaakt. Een organisatie kan dit namelijk 'ad hoc' doen of '(pro-)actief'. Met 'ad hoc' wordt bedoeld dat er wordt uitgegaan van concrete (individuele) kwalificatieproblemen, waarbij op dat moment besloten wordt tot nietsdoen, allocatie of training. Het nadeel hiervan is dat training maar ook allocatie tijd in beslag neemt, waardoor de kwalificatiediscrepantie gedurende een zekere periode blijft voortbestaan met alle kosten van dien. Dit 'probleemoplossend handelen' heeft echter als voordeel, dat het uitgaat van reële bestaande problemen en dat geen tijd, energie of kosten wordt gestoken in mogelijke toekomstige problemen die misschien vanzelf opgelost worden. Daarentegen kan een organisatie ook voor de (pro-) actieve variant kiezen. Een dergelijke organisatie wil toekomstige kwalificatietekorten of kwalificatie-overschotten kunnen voorspellen en wil daarom de interne en externe allocatie en training plannen. Bij vele organisaties heeft dit de facto geleid tot complexe 'manpower planning systems'. Het toetsingscriterium voor enerzijds 'ad hoc' beleid of anderzijds '(pro)actief' beleid kan te maken hebben met de volgende drie factoren. De feitelijke onzekerheid en de gewenste onzekerheid over de toekomst kan van belang zijn, maar ook de kosten van 'not-planning'. Als de feitelijke onzekerheid groot is, kan er beter niet gepland worden omdat dan de kans op fouten groot is. Bij een lage gewenste onzekerheid (de goede naam van de organisatie staat bijvoorbeeld op het spel), is de wil aanwezig om deze onzekerheid te reduceren door te gaan plannen. Hoge kosten van 'not-planning' (bijvoorbeeld tijdelijk produktiviteitsverlies) zullen er in dat geval toe leiden dat meer gepland zal worden.

\section{Allocatie of training}

De discrepantie tussen de vereiste en de beschikbare kwalificaties wordt veelal opgelost door middel van allocatie of training. De vereiste kwalificaties kunnen worden afgestemd op de beschikbare kwalificaties door een allocatieproces op gang te brengen, hetgeen betekent dat kwalificaties op de arbeidsmarkt gekocht of juist verkocht worden. Hierbij kan gedacht worden aan recrutering en ontslag maar ook aan uitbesteden of juist opdrachten overnemen. Anderzijds kunnen de vereiste en de beschikbare kwalificaties op elkaar worden afgestemd door training. De organisatie lost nu het discrepantie-probleem op door het personeel gevarieerde werkervaring te laten opdoen en eventueel in samenhang daarmee een scholingsprogramma voor het personeel op te zetten. Een organisatie kan dus de vereiste kwalificaties afstemmen op de beschikbare kwalificaties door het personeel te trainen (make/repair) of door te alloceren (buy/sell).

De transactiekostenbenadering heeft inzicht opgeleverd over een dergelijk keuzeprobleem ('make or buy'). De transactiekostenbenadering bouwt daarmee in feite voort op het werk van Coase, die reeds in 1937 in zijn artikel "The nature of the 
firm" de fundamentele vraag stelde: Waarom bestaan ondernemingen? Coase komt tot de verklaring dat een onderneming in feite een institutionele oplossing is om de kosten verbonden aan het prijsmechanisme te ontlopen en om bepaalde contracten te realiseren die niet gemakkelijk tot stand zouden komen in een marktrelatie (Hendrikse \& Schreuder, 1990). Williamson, die tientallen jaren later tot soortgelijke gedachten kwam en een zeer belangrijke rol heeft gespeeld in de ontwikkeling van de transactiekostenbenadering, beschouwt de transactie als de basiseenheid van analyse en de transactiekosten als het centrale element in de bestudering van organisaties (Williamson, 1981). Transactiekosten worden wel onderscheiden in drie componenten, namelijk de kosten verbonden aan het zoeken van een tegenpartij, de kosten van het opmaken van een contract en de kosten om te voorkomen dat er contractbreuk wordt gepleegd (Douma, 1988).

Transacties kunnen in zowel de markt als organisaties plaatsvinden. De keuze voor één van beide coördinatie- of afstemmingsmechanismen hangt af van de vraag of de transactiekosten (op de markt) danwel de coördinatiekosten (in de organisatie) lager zijn voor desbetreffende transacties. De omvang van deze kosten is afhankelijk van zowel de eigenschappen van menselijke factoren, als de kenmerken van de transacties. Door opportunistisch gedrag gecombineerd met een lage transactiefrequentie of een hoge 'asset-specificity' nemen de transactiekosten toe. Door 'bounded rationality' in combinatie met een hoge transactie-onzekerheid zullen de transactiekosten ook stijgen, aldus Williamson. Dus uitgaande van opportunistisch gedrag en beperkte rationaliteit van individuen zal een lage transactiefrequentie, een hoge transactiespecificiteit en een hoge transactie-onzekerheid alle drie leiden tot hogere transactiekosten en aldus tot het internaliseren van de transactie (make/repair). We zullen dit voor opleidingen uitwerken.

Naarmate de transactie specifieker wordt zal 'make or repair' meer voor de hand liggen. Medewerkers van een onderzoeksinsituut zullen bijvoorbeeld wel een cursus voor regressie-analyse gaan volgen, maar geen cursus voor snel typen. Bij kleine aantallen (potentiële) wederpartijen zal ook vaker worden overgegaan tot internalisatie. Indien bijvoorbeeld slechts één opleidingsinstituut cursussen regressie-analyse aanbiedt zal het gevaar van opportunistisch gedrag door dit instituut de kop opsteken, waardoor het misschien zinvoller is om deze bekwaamheid on-the-job aan te leren. Tot slot is volgens de transactiekostenbenadering de transactie-onzekerheid nog van belang. Naarmate er meer onzekerheid (weinig informatie en veel fluctuatie) bestaat over het aangaan en de gevolgen van een transactie, zal vaker gekozen worden voor een interne oplossing. Indien bijvoorbeeld projectleiders in zeer beperkte mate voorradig zijn op de externe arbeidsmarkt en er aldus zeer veel onzekerheid bestaat over het vinden van een geschikte projectleider, zal het wellicht beter zijn om eigen onderzoekers op te leiden tot projectleider. 
Over deze onzekerheid kan ook nog dit gezegd worden. Kwalificaties kunnen namelijk verworven worden in het reguliere onderwijs, in externe en bedrijfsopleidingen en door werkervaring (dat hier voorlopig buiten beschouwing blijft). De verwachting is dat bedrijven en instellingen in de eerste plaats gebruik zullen maken van het reguliere onderwijssysteem, in de tweede plaats van externe opleidingen en in derde plaats van bedrijfsopleidingen. Naarmate een opleiding namelijk een meer regulier karakter heeft, zal deze vaak goedkoper zijn, aangezien de overheid of de branche-instelling meebetaalt. Bovendien zal meer kennis aanwezig zijn over de gestandaardiseerde curricula van de reguliere opleidingen en daarmee over de produktiviteit van de opgeleiden, waardoor de onzekerheid kleiner is. Kenmerkend is bijvoorbeeld de uitspraak van dr. Thurlings van de afdeling opleidingen bij Philips: 'we hebben meer dan honderd cursussen, maar eigenlijk geven we ze liever niet' (Wasser, 1988).

\subsection{Training van binnenuit gezien}

In paragraaf 3.2 werd training van buitenaf bezien. Zo kwamen bijvoorbeeld de invloeden van technologische en marktontwikkelingen aan de orde. In dit gedeelte wordt de interne dynamiek van organisaties belicht. Allereerst benoemen we enkele invloedrijke organisatiekenmerken en daarna wordt een 'human resource'-model gepresenteerd.

\section{Organisatiekenmerken}

Ontegenzeggelijk is er een aantal organisatiekenmerken te onderscheiden dat van invloed is op het type en de omvang van de trainingsinspanning van organisaties. In het hoofdstuk 'Training in cijfers' hebben we al de rol van de omvang en het soort organisatie gezien. Verder valt te denken aan de produktiestructuur en de organisatie van de arbeid. Wellicht speelt ook de mate van hiërarchisering en de vigerende organisatiecultuur een rol in de omvang, maar zeker ook in het type training.

Grote organisaties doen relatief meer aan training dan kleine organisaties. Hoe kan dit nu? In hoofdstuk 2 hebben we reeds geconstateerd dat - voor wat betreft werkende schoolverlaters - dit gedeeltelijk is toe te schrijven aan het gemiddeld hogere opleidingsniveau in grote organisaties ${ }^{7}$. Omdat hoger opgeleiden een hogere kans op training hebben, is de grotere trainingsinspanning in grote organisaties dus

7. Dit positieve verband tussen het gemiddelde opleidingsniveau en de organisatiegrootte geldt overigens niet alleen voor pas afgestudeerde schoolverlaters. Er zijn diverse bewijzen dat dit voor de gehele werkzame beroepsbevolking geldt (zie voor wat betreft de industriële sector bijvoorbeeld Ten Have, 1993). 
gedeeltelijk toe te schrijven aan het hogere gemiddelde opleidingsniveau in grote organisaties. Een andere reden die vaak genoemd wordt is het economies-of-scalevoordeel voor grote organisaties. Bij grote aantallen cursisten kan bijvoorbeeld een eigen trainingsafdeling worden opgezet of kan een korting bij externe opleidingsinstituten worden bedongen. Daarnaast speelt de mogelijkheid dat grote organisaties een betere toegang tot de kapitaalmarkt hebben en risico's ook beter door een grotere spreiding kunnen wegmiddelen ('poolen'). Er is immers altijd een risico bij training, omdat de cursus soms niet voltooid wordt, het geleerde niet in de praktijk gebruikt wordt (beperkte transfer), het geleerde niet leidt tot een hogere produktiviteit of omdat de getrainde persoon de organisatie ongewild verlaat. $\mathrm{Bij}$ grote organisaties is evenwel de kans groter dat enkele negatieve uitschieters opwegen tegen enkele positieve uitschieters, waardoor het totale risico geringer wordt. Verder wordt wel gesteld dat grote bedrijven dankzij hun mogelijkheden tot interne mobiliteit een geringere kans op vrijwillige externe mobiliteit hebben. Het risico op (menselijk) kapitaalverlies zou hierdoor kleiner zijn, hetgeen een economische rechtvaardiging voor het creëren van een interne arbeidsmarkt zou bieden. Op basis van een onderzoek onder ongeveer 600 Nederlandse industriële bedrijven (Ten Have, 1993) blijkt inderdaad dat er sprake is van een negatieve correlatie tussen (de logaritme van) de bedrijfsomvang en het percentage vrijwillig vertrek. Hetzelfde onderzoek toont echter ook aan dat er geen sprake is van een afruil tussen interne mobiliteit en vrijwillige externe mobiliteit. Dus grotere organisaties hebben te maken met een iets lager percentage vrijwillig vertrek, maar dit heeft op voorhand niet te maken met de hogere interne mobiliteit in grote organisaties, maar wellicht met het daar aanwezige hogere beloningsniveau.

In sommige bedrijfsklassen wordt meer getraind dan in andere bedrijfsklassen. Een bedrijfsklasse kan hierbij gezien worden als de historische neerslag van een specifieke verzameling van produktieorganisaties met grote onderlinge verwantschap in de aard van de voortgebrachte goederen of diensten en de toegepaste produktietechnieken. Zij zijn hierdoor onderhevig aan gelijksoortige technologische en marktontwikkelingen. Er zijn echter zoveel verschillende bedrijfsklassen en nog meer verschillende branches, dat er behoefte bestaat om soorten organisaties volgens een meer abstracte dimensie in te delen. Daartoe kan bijvoorbeeld de Tayloristische produktie-organisatie worden afgezet tegen de sociotechnische produktieorganisatie. De Tayloristische produktie-organisatie kenmerkt zich door maximale arbeidsdeling en de sociotechnische produktie-organisatie door minimale arbeidsdeling (Kuipers, 1989). Dit zijn de beide extremen en daar tussenin ligt een scala van varianten en nuanceringen zoals bijvoorbeeld 'lean produktion' (Womack, Jones \& Roos, 1991) waar boekenkasten over zijn vol geschreven maar nu niet verder op ingegaan wordt. In elk handboek over organisaties staat beschreven dat een Tayloristische produktie-organisatie veel gebruik maakt van laag gekwalificeerde arbeid. Training is in zo'n Tayloristische produktie-organisatie nauwelijks 
nodig en vindt hooguit on-the-job plaats en is gericht op een specifieke deeltaak. Lijnrecht daartegenover staat het sociotechnische design (met als belangrijke representanten De Sitter, Kuipers, Van Amelsvoort en Van Eynatten). Het traditionele, functionele produktieconcept van de organisatie wordt hierbij vervangen door het nieuwe stroomgerichte produktieconcept, gebaseerd op parallelliseren en segmenteren, waarbij de organisatie-inrichting uit de volgende elementen bestaat: de zelfstandige produktiegroep, de operationele groep en de business unit (Kuipers \& Van Amelsvoort, 1990).

Op de produktiegroep zullen we nog even verder ingaan. Het is de grootste organisatorische eenheid die intern ongedeeld kan functioneren en waarin zich bij uitstek de principes van 'zelforganisatie' laten realiseren. De ongedeelde produktiegroep met een 'hele taak' mobiliseert door haar structuur, motivatie en betrokkenheid en activeert op die basis vier binnen zelforganiserende groepen vereiste kwaliteiten. Deze zijn brede inzetbaarheid, inzicht in het procesverloop, subtiel samenspel en een creatieve 'double look' (Kuipers, 1989). Bij een sociotechnische produktieorganisatie zijn dus veel méér en ook heel andere kwalificaties vereist dan in een Tayloristische produktie-organisatie.

Een andere toonaangevende invalshoek in de organisatieliteratuur is die van de contingentiebenadering, met als meest bekende representant Mintzberg. Mintzerg onderscheidt in zijn Structures in Fives (1983) vijf configuraties op basis van dominante situationele factoren, ontwerpparameters, structuurkenmerken en coördinatiemechanismen. Deze vijf configuraties zijn de eenvoudige structuur, de machinebureaucratie, de professionele bureaucratie, de divisiestructuur en de adhocratie. Bij de eenvoudige structuur en de machinebureaucratie is er weinig behoefte aan training, bij de divisiestructuur is er slechts enige behoefte aan training bij de divisiemanagers en bij de professionele bureaucratie en de adhocratie is er veel behoefte aan training op alle niveaus van de organisatie. Volgens Mintzberg is bij de professionele bureaucratie de standaardisatie van kennis en vaardigheden zelfs het belangrijkste coördinatiemechanisme in de organisatie.

Tot slot kan de organisatiecultuur, of bijvoorbeeld de dominante leiderschapsstijl, een betekenis hebben in de omvang maar vooral ook het type training. Deze 'softere' benadering komt bijvoorbeeld tot uitdrukking in het volgende citaat:

'De wereld verandert snel. De mens is steeds beter opgeleid en mondiger geworden. Mede daardoor werkt de traditionele 'command en control'structuur van organisaties niet meer. Internationaal is de tendens op gang gekomen om organisaties - zowel bedrijven als overheden - slagvaardiger te maken. Terug naar de menselijke maat' is daarbij het credo. Of met andere woorden, de 'command en control'-structuur wordt vervangen door een 'involve and inspire'-structuur, waarin het personeel zowel 'meedoet' als 
'meedenkt'. Het 'top-down-model' is uit en 'inside-out' is in (Huibregtsen \& Van Lierop, 1991).

In een organisatietype waarin 'involve and inspire' overheerst zullen ook bepaalde typen kwalificaties vereist zijn. Enerzijds zullen meer algemene, cognitieve kwalificaties nodig zijn, ten einde in diverse omstandigheden en op verschillende niveaus te kunnen 'meedenken'. Anderzijds zullen ook meer algemene, sociale kwalificaties vereist zijn zoals onderhandelen, adviseren, presenteren en conflicthantering. Bovendien zullen leiderschapsstijlen aan verandering onderhevig zijn. In plaats van een autoritaire, directieve leiderschapsstijl, zal een mens- en taakgerichte stijl gaan overheersen. Kortom, in een organisatieklimaat van 'involve and inspire' zal een divers palet van algemene kwalificaties vereist zijn.

Een 'human resource'- model

Training staat in relatie met allerlei andere 'human resource'-domeinen in een organisatie. Het is verbonden met de in-, door- en uitstroom van werknemers, maar bijvoorbeeld ook met de beloning en niet te vergeten de produktiviteit. Het is zinloos training sec op te vatten, zonder rekening te houden met de overige 'human resource'-domeinen. Zowel het dynamische, het subjectieve als het ruiltheoretische karakter dienen tot uitdrukking te worden gebracht. Vandaar dat training wordt verbonden met mobiliteit, beoordeling, beloning en produktiviteit.

Figuur 3.2

Het 'human resource'-model

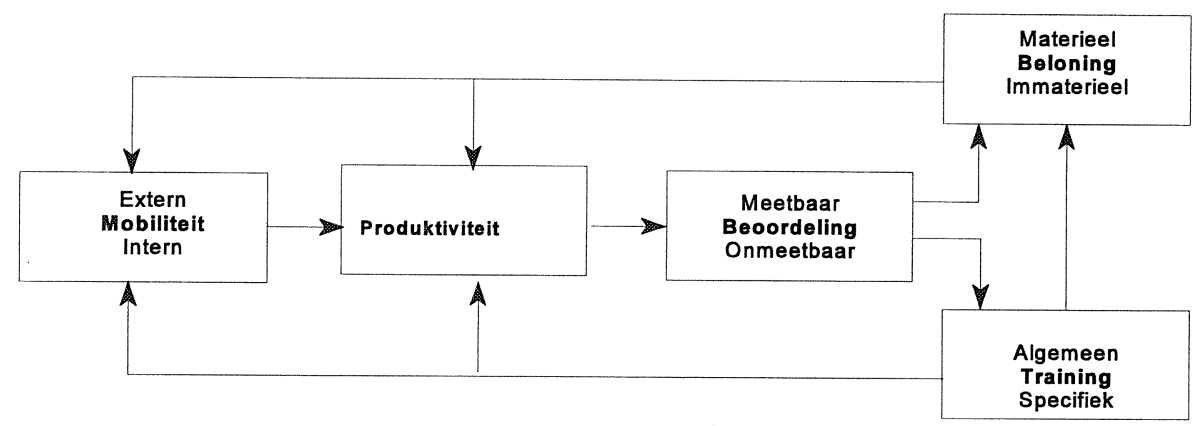

Tichy, Fombrun \& Devanna (1982) beschouwen 'human resource management' als een belangrijke strategische factor in het functioneren van een organisatie. In het licht van deze strategische rol van 'human resource management' ontwikkelden zij een zogenaamde 'human resource cycle' (zie bijlage III). De auteurs benoemen vier generieke processen of functies, die in alle organisaties worden uitgevoerd, namelijk 
selectie, beoordeling, beloning en ontwikkeling. De afhankelijke variabele is 'performance', waarbij de 'human resource' elementen zodanig worden ontworpen dat zij op zowel individueel als organisatieniveau de 'performance' beïnvloeden. Hun 'human resource cycle' heeft de aanzet gegeven tot een eigen versie, die in figuur 3.2 is weergegeven.

Verderop zal uitgebreid worden ingegaan op de variabelen en de relaties tussen de variabelen en zullen ook een drietal dominante configuraties worden afgeleid. Allereerst zal echter kort worden aangegeven waarom ten dele van de oorspronkelijke 'human resource cycle' van Tichy, Fombrun \& Devanna wordt afgeweken en waarom een aanvulling heeft plaatsgevonden (vergelijk bijlage III met het onderstaande model). De variabelen 'performance', 'rewards' en 'appraisal' zijn gehandhaafd en vertaald in respectievelijk produktiviteit, beloning en beoordeling. Verder is de voorkeur gegeven aan het begrip 'training' boven 'development' om een tweetal redenen. Allereerst is de term 'training' concreter dan 'development'. Op de tweede plaats duidt 'development' op dynamiek en interne mobiliteit. Voor zover dit van toepassing is, zou dat beter bij het nieuwe blok 'mobiliteit' kunnen worden geplaatst. Dan komen we op de belangrijkste wijziging van het model van Tichy, Fombrun en Devanna. Deze auteurs hebben 'selectie' opgevat als een centraal proces (of functie), terwijl het slechts één deel van de uitwisseling met de externe arbeidsmarkt bevat. Gedwongen ontslag, natuurlijk en vrijwillig verloop zijn namelijk ook uitwisselingen met de externe arbeidsmarkt, die minstens zo belangrijk zijn.

Een bijkomend argument is, dat 'selectie' in feite niets anders is dan de beoordeling van de (verwachte) produktiviteit. Al met al lijkt het opportuun om het begrip 'mobiliteit' op te nemen, met een onderverdeling naar interne en externe mobiliteit. Op deze manier worden bovengenoemde bezwaren ondervangen en wordt bovendien het dynamische element van een 'human resource'- model belicht. Ook de andere centrale variabelen zijn verder opgedeeld op basis van de meest dominante dimensie. Beloning is verder opgesplitst in materiële \& immateriële beloning, training in algemene en specifieke training, terwijl beoordelingen worden beheerst door de mate van meetbaarheid.

Het model is in feite de weergave van de historische ontwikkeling in de economische theorievorming omtrent arbeidsvraagstukken. Hierbij kan worden begonnen bij $A$. Smith met zijn klassieke theorie over compenserende loonverschillen. De externe mobiliteit van werknemers vormde het mechanisme dat leidde tot loonevenwicht. Bovendien werd in deze klassieke theorie impliciet erkend dat er zowel materiële als immateriële loonbestanddelen bestaan zoals slechte arbeidsomstandigheden of vast werk. Hierbij werd arbeid beschouwd als homogeen goed, waarbij één loonniveau hoorde. Dit bleek een weinig realistische veronderstelling te zijn, hetgeen leidde tot de werkhypothese dat arbeid best heterogeen kan zijn. De 
produktieve capaciteiten kunnen per individu verschillen en toe- of afnemen door respectievelijk scholing en slijtage. Dientengevolge kunnen er ook verschillende loonniveaus bestaan en kunnen investeringen in menselijk kapitaal rendabel zijn. Met de komst van de 'human capital'-theorie wordt dit nog nader gespecificeerd: individuen kunnen niet alleen verschillen in capaciteiten voor wat betreft de hoeveelheid kwalificaties maar ook in het type kwalificaties. Alleen algemene kwalificaties zullen tot een hoger loonniveau leiden. Na deze eerste revolutie kwam de tweede revolutie in de arbeidseconomie: onzekerheid en beperkte informatie (Hartog \& Theeuwes, 1993). De beoordeling van de produktiviteit en ook de beoordeling van de hoeveelheid en type kwalificaties heeft te kampen met informatiegebreken, informatieassymmetrieën, onzekerheden en beperkte rationaliteit. Het enige 'human resource'-domein dat dan nog resteert is de interne mobiliteit. Dit is nog steeds een min of meer onbeschreven blad voor de economische theorievorming, ofschoon deze ook op dit terrein langzaam loskomt. Al met al breidt het domein van de economische theorievorming alsmaar uit. Of, zoals arbeidseconomen als Hartog \& Theeuwes (1990) schrijven:

'Arbeidseconomen zijn in hun denken steeds verder afgedwaald van het simpele idee van de arbeidsmarkt werkend als een veilingmarkt. Er wordt nu veel meer erkend dat institutionele elementen, dynamische en onzekerheidsaspecten, ethische en rechtvaardigheidsoverwegingen de arbeidsmarkt tot iets bijzonders maken. Op dit moment weten we veel over deelaspecten, en meestal zijn dat fenomenen die we vroeger ook al kenden, of die de institutionalisten reeds benadrukten, maar die we nu beter theoretisch kunnen onderbouwen. De neoklassieke visie unificeert, annexeert en pontificeert, maar excommuniceert niet. Alles wordt meegenomen en van niemand wordt een heilige koe geslacht'.

De relatie tussen training en produktiviteit

Produktiviteit is de opbrengst van een werknemer voor de organisatie. Deze kan bestaan uit een hogere kwantitatieve output per tijdseenheid, meer omzet, een hogere kwaliteit van de produkten of diensten, minder klachten van klanten, minder storingen van machines, kortere instel- en omsteltijden, meer innovatie etc. De verwachte totale produktiviteit is de verwachte, contante waarde van de toekomstige produktiviteit.

Onder training wordt het verwerven en onderhouden van kwalificaties in organisaties verstaan, daarbij variërend van on-the-job-training (bestaande uit learning-by doing, werkoverleg, kwaliteitscircels, instructies geven e.d.) tot formele, off-the-job training. Kwalificaties zijn vaardigheden, kennis en attitudes/inzichten. Off-the-job training kan feitelijk zowel binnen als buiten de organisatie plaatsvinden. Het CBS spreekt in dit kader over het onderscheid in bedrijfs- en externe opleidingen. 
Bedrijfsopleidingen zijn opleidingen die uitsluitend toegankelijk zijn voor personen die werken bij het desbetreffende bedrijf of instelling, of bij een moeder-, dochter-, of zusterbedrijf, terwijl externe opleidingen tevens toegankelijk zijn voor personen die niet werken bij het desbetreffende bedrijf of instelling, of bij een moeder-, dochter-, of zusterbedrijf (CBS, 1992).

De 'human capital' theorie (Becker, 1980) leert dat de toekomstige produktiviteit van werknemers verhoogd kan worden door gerichte uitgaven op de korte termijn. In de theorie van het menselijk kapitaal staat centraal dat training, analoog aan het investeren in fysiek kapitaal, kan worden gezien als een investeringsbeslissing. Het muteren van kwalificaties moet dan niet met consumptiemodellen maar met investeringstheorieën worden geanalyseerd. De hoeveelheid en type kwalificaties, oftewel het menselijke kapitaal, wordt beschouwd als een 'stock'-variabele, terwijl door middel van initieel onderwijs, off-the-job training en on-the-job training tot accumulatie van menselijk kapitaal in organisaties gekomen kan worden (zie ook Cörvers, 1994). Kwalificaties kunnen om diverse redenen ook verouderen of minder waard worden, zodat tevens het menselijk kapitaal aan afschrijving onderhevig is.

De specificiteit van een investering in menselijk kapitaal is een belangrijk element in de 'human capital' theorie. Specifieke kwalificaties zijn namelijk niet alternatief aanwendbaar en/of hebben bij alternatieve aanwending geen waarde. Daarbij is zowel organisatie-, branche-, en functiespecificiteit te onderscheiden. Organisatiespecifiek menselijk kapitaal kan alleen produktief worden aangewend in de organisatie waarin men werkzaam is. Branchespecifiek menselijk kapitaal kan alleen maar produktief aangewend worden in de branche waar men werkzaam is en functiespecifiek menselijk kapitaal kan alleen produktief aangewend worden in dezelfde soort functies waarin men werkzaam is. Het algemeen voortgezet onderwijs legt de nadruk op de ontwikkeling van algemene kwalificaties, het beroeps(-voorbereidend) onderwijs legt de nadruk op functiespecifieke kwalificaties, en bedrijfsscholing en on-the-job training leggen vooral de nadruk op de verdere uitbouw van zowel functie- als bedrijfsspecifieke kwalificaties (De Grip, Groot, Heijke, Willems, 1990). De specificiteit van een investering in kwalificaties is belangrijk, omdat deze namelijk gevolgen heeft voor de beloning, de mobiliteit (zie verderop) en de produktiviteit.

Een algemeen aanvaarde veronderstelling is dat door training de produktiviteit stijgt. Gerichte uitgaven op korte termijn kunnen op langere termijn leiden tot een hogere produktiviteit. Functionalistisch geredeneerd, zal er geen training plaatsvinden als het niets oplevert, met het gevaar: 'what is, is best'. Werknemers die beschikken over de juiste, specifieke kwalificaties zullen op korte termijn produktiever zijn. De onjuist specifiek gekwalificeerden zullen daarentegen pas na een adequate 'matching' van werk en kwalificaties hun kwaliteiten produktief kunnen aanwenden. Werknemers, die vooral algemeen gekwalificeerd zijn, zullen op de korte termijn een 
lagere produktiviteit genereren dan degenen met de juiste specifieke kwalificaties. Deze algemeen gekwalificeerden kunnen echter wellicht op langere termijn tot een hogere produktiviteit komen, en wel om twee redenen. Als gevolg van sneller veranderende taakinhouden en als gevolg van een intern mobiliteitsbeleid zullen algemeen opgeleide werknemers regelmatig van werkzaamheden kunnen wisselen. Op langere termijn zouden deze algemene kwalificaties dan nuttiger kunnen zijn dan (al te) specifieke kwalificaties, omdat de verwachting is dat bij de algemeen gekwalificeerden het saldo van de trainingsopbrengsten en trainingskosten groter is. Dit alles impliceert dat het individuele loonprofiel van algemeen gekwalificeerden steiler is dan van specifiek opgeleiden.

De relatie tussen training en mobiliteit

Onder mobiliteit wordt wisseling van werk verstaan. Dit kan een wisseling van het functieniveau inhouden (horizontaal, opwaarts, neerwaarts), maar ook een wisseling van de plaats (geografisch), een wisseling van het soort werk (functie, beroep), of een wisseling van de aanbieder van het werk (organisatie, sector). Wisseling van werk binnen een organisatie wordt interne mobiliteit genoemd, terwijl de wisseling van de ene naar de andere organisatie, externe mobiliteit heet. Aangezien in dit rapport de organisatie als analyse-eenheid genomen wordt, is het onderscheid tussen externe en interne mobiliteit van groot belang. Bij externe mobiliteit kan het gaan om zowel instroom of werving als uitstroom of verloop. Verder wordt bij verloop onderscheid gemaakt tussen vrijwillig verloop en onvrijwillig verloop (pensionering, WAO, ontslag).

Een werknemer raakt door het verwerven van specifieke kwalificaties gebonden aan het werk dat op dat moment verricht wordt. Aan alternatieve aanwending van specifieke kwalificaties zijn namelijk kosten verbonden (inleertijd e.d). De mobiliteit zal navenant geringer zijn. Op deze manier zullen organisatiespecifieke kwalificaties leiden tot een geringere mobiliteit tussen organisaties, aangezien bij externe mobiliteit de gekapitaliseerde waarde van specifieke kwalificaties verloren gaat. Branchespecifieke kwalificaties hoeven daarentegen niet ten koste te gaan van de mobiliteit tussen organisaties, maar zullen daarentegen wel ten koste gaan van de mobiliteit tussen branches. In de horeca is het bijvoorbeeld gebruikelijk om af en toe te wisselen van werkgever, maar blijt men veelal wel in dezelfde branche actief. Dit duidt erop dat de kwalificaties in de horeca niet organisatie- maar branchespecifiek van aard zijn. Als functiespecifieke kwalificaties worden verworven, zal in principe de (interne) mobiliteit tussen functies geringer zijn. Het wisselen van functie gaat namelijk gepaard met kosten. Algemene kwalificaties zullen daarentegen geen belemmering vormen voor de mobiliteit. Indien er een hoge kans bestaat op externe mobiliteit, zal de werkgever in een kortere periode zijn investering moeten terugverdienen, waardoor de kans op training afneemt. Anders gezegd: de baten moeten 
wel erg hoog zijn - gegeven de hoge kans op externe mobiliteit - om een investering in training in algemene kwalificaties lucratief te laten zijn. Een organisatie zal in zijn algemeenheid alleen bereid zijn voor training te betalen die bij werknemers specifieke kwalificaties genereren, hetgeen dan gepaard gaat met een afnemende kans op externe mobiliteit.

Verder kan op basis van de 'human capital' theorie nog iets gezegd worden over enkele persoons- en werkgebonden kenmerken zoals het geslacht, de leeftijd, het verrichten van part-time werk en anciënniteit. De kans op externe mobiliteit is bij vrouwen door de bank genomen groter, aangezien zij vaker hun loopbaan onderbreken wegens zwangerschap, opgroeiende kinderen e.d. De bereidheid van organisaties tot het trainen van vrouwen zal daarom geringer zijn. Het verwachte rendement wordt door de hogere gepercipieerde kans op vrijwillig verloop namelijk lager. Voor ouderen en deeltijdwerkers geldt eveneens een relatief laag verwacht rendement, zodat ook hier de investering in het verkrijgen kwalificaties lager zal zijn (Teulings \& Budil-Nadvornikova, 1989). Door anciënniteit in een functie worden in het algemeen functiespecifieke kwalificaties verworven (learning-by-doing). Door anciënniteit in een organisatie worden bovendien organisatiespecifieke kwalificaties verworven. Aangezien functie- en organisatiespecifieke kwalificaties sterk samenhangen zal anciënniteit zowel een lagere externe als een lagere interne functiemobiliteit tot gevolg hebben. Dit noemt men wel de negatieve baanduurafhankelijkheid van mobiliteit.

De relatie tussen training en beloning

In de 'human capital' theorie wordt, zoals eerder besproken het belangrijke onderscheid tussen algemene en specifieke kwalificaties gemaakt. Als werknemers kwalificaties hebben of opdoen die algemeen van aard zijn, dan kunnen deze werknemers hun kwalificaties op de externe arbeidsmarkt te gelde maken. Hierdoor zal de beloning moeten stijgen. Indien werknemers echter, door bijvoorbeeld on-the-job training, kwalificaties verwerven die specifiek (bijvoorbeeld on-the-job training) van aard zijn, dan zullen zij deze kwalificaties niet alternatief kunnen aanwenden, waardoor ze ook niet te gelde gemaakt kunnen worden. Naarmate training specifieker van aard is, zal de opbrengst van de training meer bij de werkgever komen te liggen. Bij volledig organisatiespecifieke kwalificaties van de werknemer hoeft er uit het rationeel economisch oogpunt van de werkgever géén relatie te zijn tussen de produktiviteit van een werknemer in de eigen organisatie en zijn of haar beloning. De beloning volgt immers de produktiviteit van de werknemer bij een andere werkgever. Maar ook Becker (1980) stelt dat in de praktijk training in organisaties tegelijkertijd zowel een specifieke als een algemene component zal hebben. In de praktijk zal hierdoor een gedeelte van het via training in organisaties verkregen menselijke kapitaal altijd ook op de externe markt verkoopbaar zijn. In dat geval en 
in die mate zal de beloning de produktiviteit volgen.

Rationele werkgevers zullen het beloningsniveau afstemmen op de hoeveelheid algemene kwalificaties van hun werknemers en, in eerste instantie, niet op de produktiviteit van de werknemers in de eigen organisatie. Het type en het niveau van de initiële opleiding, de gecertificeerde off-the-job training (bijvoorbeeld de NIVRA-opleiding tot registeraccountant), maar ook sommige on-the-job training (bijvoorbeeld sociale vaardigheden) zullen bepalend zijn voor de hoogte van de beloning. Als gevolg van specifieke en ondoorzichtige kwalificaties zal de hoogte van de beloning kunnen afwijken van de hoogte van de produktiviteit. In deze situatie bestaat voor de werkgever het risico dat (de contante waarde van) het voor de werkgever gunstige verschil tussen beloning en produktiviteit verloren gaat, omdat de werknemer ontslag neemt. Een werkgever kan besluiten dit risico te verminderen door een opslag op het loon te betalen (Hashimoto, 1981). De opbrengsten van specifieke training worden in dat geval toch tussen werkgever en werknemer gedeeld. Ofschoon er voor de werknemer geen belang is om te vertrekken kan de werkgever er toch een stukje extra beloning voor over hebben om het risico van een eventueel vertrek zoveel mogelijk te vermijden.

Training, en met name het volgen van bedrijfs- en externe opleidingen, wordt daarnaast door veel werknemers opgevat als een immateriële beloning. Rationele werkgevers die hun werknemers bedrijfs- of externe opleidingen laten volgen, zullen dit aan hun werknemers ook als een extra (immateriële) beloning presenteren, omdat dan de materiële lonen niet hoeven te stijgen. Daarentegen zal een slimme werknemer in het onderhandelingsspel het volgen van bedrijfs- en externe opleidingen definiëren als een produktieve bijdrage, die extra gecompenseerd zal moeten worden in materieel loon. Het onderhandelingsspel zal echter meer naar de hand van de werkgever gezet worden, aangezien deze veelal over meer informatie beschikt en de risico's over alle werknemers kan uitsmeren. Naarmate door werknemers training meer als een immateriële beloning wordt opgevat zal de extra materiële beloning lager zijn.

De relatie tussen mobiliteit en produktiviteit

Indien goed en juist gekwalificeerde personen instromen in een organisatie zal dit de produktiviteit van de organisatie verhogen. De desbetreffende kwalificaties kunnen verworven zijn in het initiële (beroeps-)onderwijs maar ook bij andere organisaties. De juiste matching tussen de benodigde en de geboden kwalificaties zal bij de selectie van nieuw personeel van doorslaggevend belang zijn. Indien een organisatie hierin slaagt zal de produktiviteit, op korte en eventueel ook op langere termijn, toenemen. Bij ontslag, vrijwillig verloop of pensionering zal de contante waarde van het overschot van de verwachte toekomstige produktiviteit boven de 
kosten, verloren gaan. Dit betekent menselijk kapitaalverlies, oftewel de waarde van het 'human capital' moet ineens worden afgeschreven. De leeftijd is dus van wezenlijk belang bij een mogelijk kapitaalverlies. Ouderen brengen mutatis mutandis bij externe mobiliteit dan ook minder schade toe aan de organisatie. De contante waarde van de toekomstige produktiviteit is simpelweg minder door het kleinere aantal toekomstige arbeidsjaren. Externe mobiliteit kan echter voor een organisatie ook gunstig uitpakken. Indien namelijk de verwachte contante waarde van de nettobaten minder is dan de contante waarde van de netto-baten van een alternatieve investering in fysiek of menselijk kapitaal, zal vrijwillig verloop of ontslag gunstig zijn. Dit verklaart wellicht de populariteit van de VUT of de WAO als een gemakkelijke uitstroommogelijkheid van minder produktieve werknemers bij een ruime arbeidsmarkt.

In de relatie tussen interne mobiliteit en produktiviteit spelen twee tegengestelde effecten een rol. Allereerst leidt interne mobiliteit tot extra kosten voor de werkgever, aangezien bij elke wisseling van werk de werknemer eerst vaardigheden, kennis, attitudes en inzichten over het werk zal moeten opdoen. Er zal telkens een inleertijd zijn, werknemers moeten andere cursussen gaan volgen etc. Kortom, door interne mobiliteit wordt het human resource model een aantal keren doorlopen, met alle trainingskosten van dien. Daartegenover kan interne mobiliteit ook gunstig zijn voor de produktiviteit. Werknemers die gedurende lange tijd hetzelfde werk verrichten kunnen 'verblind' raken. Een 'frisse wind' kan nieuwe inzichten opleveren, hetgeen de kwaliteit van de arbeidsprestatie ten goede kan komen.

Welke van bovengenoemde effecten de overhand zal hebben, is vooralsnog onduidelijk. Wellicht zal het functieniveau een intermediërende rol spelen. Bij lage functieniveaus zal vooral een beroep worden gedaan op de fysieke vaardigheden en functiegerichte kennis van individuen. Naarmate het functieniveau hoger is, zullen inzichten een begerenswaardige kwalificatie vormen. Het regelmatig genereren van nieuwe inzichten kan dan van groot belang zijn voor de uitvoering van de functie. Daarom zal interne mobiliteit alleen bij de hogere functieniveaus renderen, zo is de verwachting.

De relatie tussen produktiviteit en beoordeling

De produktiviteit van werknemers wordt door het management beoordeeld. De koppeling tussen produktiviteit en beoordeling is echter geen een-op-een relatie, aangezien zowel een objectieve als een subjectieve component is te onderscheiden. Naast de objectieve component, de feitelijke arbeidsprestatie, is er een subjectieve component, dit is de perceptie die de beoordelaar heeft van deze prestatie (Von Grumbkow, 1982). Dit impliceert dat een individu op beide componenten invloed zou kunnen uitoefenen, waar Von Grumbkow uit afleidt dat loon tot 
stand komt uit zowel de arbeidsprestatie als de 'politieke' prestatie. Dit effect moet overigens niet overdreven worden, aangezien op den duur slechte beoordelaars zèlf slecht beoordeeld zullen worden. Maar laten we in ieder geval vaststellen dat er informatie nodig is over de hoogte van de (toekomstige) produktiviteit, dat deze informatie vaak onvolledig en ondoorzichtig is, soms verkeerd getimed (zie ook het zgn. 'garbage-can' model!) en in ieder geval gerelateerd is aan de beperkte rationaliteit van individuen. Vandaar dat bij het begrip 'beoordeling' de mate van meetbaarheid van de produktiviteit een grote rol speelt. Hierbij dient opgemerkt te worden dat onmeetbaarheid en meetbaarheid moeten worden opgevat als twee extreme posities binnen een scala van mogelijkheden.

In de 'screening'-theorie (Spence, 1974) wordt onderwijs opgevat als een leverancier van informatie over persoonlijke geschiktheidskenmerken. Werkgevers hebben namelijk beperkte informatie over de capaciteiten en kwalificaties van (potentiële) werknemers en zijn daarom op zoek naar signalen, die een indicatie geven van de produktiviteit. Het onderwijs vergroot niet zozeer de individuele bekwaamheid, maar onthult welke individuen reeds van zichzelf het meest bekwaam zijn, aldus de 'screening'-theorie. Daarbij vormt het bereiken van een bepaald opleidingsniveau tevens een indicatie voor produktieve eigenschappen als doorzettingsvermogen, aanpassingsvermogen en leervermogen. Het bereikte onderwijsniveau, maar ook het al dan niet afronden van een bedrijfs- of externe opleiding zou kunnen fungeren als een voorspeller ('screening device') van de produktiviteit. Dit gebruik van indirecte voorspellers zal groter zijn naarmate de meetbaarheid van de produktiviteit kleiner is.

De relatie tussen beoordeling en training

Beperkte informatie over de omvang en samenstelling van de kwalificaties van werknemers wordt macro-economisch als schadelijk voor de marktwerking beschouwd. Het leidt namelijk tot een minder efficiënte allocatie en het wordt ook wel getypeerd als 'marktimperfectie'. De overheid of nationale belangenorganisaties zullen trachten de kwalificatiestructuur zo doorzichtig mogelijk te maken. Dit leidt tot de roep om een helder ingericht initieel onderwijssysteem met een beperkt aantal studierichtingen die reeds in de praktijk hun waarde hebben bewezen en ook tot de roep om een zoveel mogelijk gecertificeerde kwalificatiestructuur (zie bijvoorbeeld Lindley \& Hogarth, 1993). Katz en Ziderman (1990) merken echter heel terecht op dat hieraan op micro-niveau (lees: organisatie-niveau) ook nadelen kleven. Certificering kan namelijk tot minder training leiden. Kwalificaties worden door certificering namelijk doorzichtiger, waardoor een andere werkgever minder kosten hoeft te maken om de produktiviteit van een potentiële werknemers te kunnen beoordelen. Organisaties zullen normaal gesproken erg terughoudend zijn om te investeren in doorzichtige (en/of algemene) kwalificaties van hun werknemers, 
omdat de werknemers de baten zullen incasseren (in de vorm van een hogere beloning). Aldus zal dit op het geaggregeerde macro-economische niveau tot een onderinvestering van training door organisaties leiden.

De relatie tussen beoordeling en beloning

In de theorie van de principaal en de agent (zie Douma, 1987) wordt de relatie tussen beoordeling en beloning centraal gesteld en wordt een theoretisch raamwerk opgebouwd rondom de optimale contracten tussen werkgever (principaal) en werknemer (agent). Dit raamwerk heeft betrekking op de verdeling van risico's en beloningen, uitgaande van het onvolledig kunnen inschatten van het inspanningsniveau van het personeel ('moral hazard'). Hierbij zijn er twee extreme mogelijkheden, namelijk (1) de beloning van de agent is volledig van de winst afhankelijk, waardoor het risico in zijn geheel bij de werknemer ligt, of (2) de beloning van de agent is in zijn geheel niet van de winst afhankelijk, waardoor het risico helemaal bij de werkgever ligt. Een belangrijke uitkomst van de theorie van de principaal en de agent is, dat de optimale beloningsstructuur altijd een deling zal inhouden van het resultaat (en dus van het risico) tussen werkgever en werknemer (Douma, 1987).

Beloning is al hetgeen werknemers ontvangen voor hun werkzaamheden. In het model is echter onderscheid gemaakt tussen materiële bestanddelen (geld, vakantietoeslag) en immateriële bestanddelen (aard van de werkzaamheden, vastigheid, macht, status, carrière, gezelschap, ontwikkeling etc.). Mensen zullen trachten hun beloningen te maximaliseren (Von Grumbkow, 1980). Zij ruilen hun geleverde inspanning, bijdragen, capaciteiten tegen een adequate beloning, waardoor men überhaupt komt werken, gemotiveerd is of niet vertrekt. Dit is het ruiltheoretische uitgangspunt. Werknemers zullen tegen een hoger loon, bereid zijn banen met een grotere inspanning of slechtere werkomstandigheden te accepteren. Dit komt dus overeen met A. Smith's theorie van compenserende loonverschillen. Als vast werk als een immateriële beloning wordt beschouwd, dan zou men kunnen stellen dat de zogenaamde contracttheorieën niets anders zijn dan een nadere verbijzondering van A. Smith's klassieke theorie. De contracttheorieën zoeken namelijk verklaringen voor het feit dat de feitelijke lonen kunnen afwijken van het evenwichtsloon. In de impliciet-contractheorie wordt onder meer gesteld dat risico-averse werknemers een hoger nut hebben bij lage, vaste lonen dan bij gemiddeld hogere, maar flexibele lonen (Wolfs, 1988). De toename van het risico voor de werkgever - dat gedeeltelijk afgewenteld wordt op de aandeelhouders - zal niet opwegen tegen de lagere loonkosten. Het zal dus leiden tot een afruil tussen materiële beloning (minder loonkosten) en immateriële beloning (vast werk voor de werknemer en meer risico voor de werkgever). 
De relatie tussen beloning en produktiviteit

Door een hogere beloning zou de produktiviteit kunnen toenemen. Werknemers die hun eigen opbrengsten willen maximaliseren, kunnen trachten hun produktiviteit te verhogen in de hoop en verwachting dat dit leidt tot een hogere, al dan niet materiële, beloning. Op zich hoeft een hogere produktiviteit nog niet te leiden tot een hogere beloning, aangezien dit afhankelijk is van de mogelijkheden van de individuele werknemer om zijn of haar kwalificaties alternatief aan te wenden (tenminste volgens de 'human capital'-theorie). Kortom, het loonniveau is in principe afhankelijk van aanbod en vraag op de externe arbeidsmarkt c.q. van de waarde van de produktiviteit op de externe arbeidsmarkt. 'Efficient-wage models' (zie bijvoorbeeld Akerlof \& Yellen, 1987) gaan er daarentegen vanuit dat op zogenaamde primaire markten lonen aangetroffen kunnen worden die hoger zijn dan het loonniveau op de externe arbeidsmarkt. Deze theorie moet hierbij echter de veronderstelling maken dat lonen en produktiviteit elkaar wederzijds beïnvloeden. Daartegenover staat de 'human capital'-theorie die stelt dat de beloning slechts zal stijgen, naarmate en voor zover de kwalificaties van werknemers een algemeen karakter hebben. Door een algemeen karakter van de kwalificaties zal namelijk ook de potentiële produktiviteit bij concurrenten stijgen. Volgens de uitgangspunten van de human capital theorie zou men kunnen zeggen dat in feite niet de produktiviteit in de eigen organisatie bepalend is voor de beloning, maar dat de potentiële produktiviteit bij een naaste of nabije concurrent doorslaggevend is voor de hoogte van de beloning.

De relatie tussen beloning en mobiliteit

Behoudens de eventuele geldigheid van de efficient-wage en de transactiekostentheorie, zal toch vooral de confrontatie van de aanbod- en vraagcurve op de externe arbeidsmarkt (eventueel voor een deelmarkt) de beloning bepalen. In een markt met volledige concurrentie zal een individuele werkgever geen invloed hebben op het evenwichtsloon. Een werknemer die zijn beloning maximaliseert zal telkens de materiële en immateriële beloning bij de huidige werkgever afwegen tegen de materiële en immateriële beloning bij een alternatieve werkgever. Rekening houdend met een bepaalde individuele mate van risico-aversiteit en rekening houdend met bepaalde kosten van mobiliteit wegens verhuizing, pensioenbreuk, loopbaan van de partner etc., zal een werknemer bij (grote) discrepanties besluiten de organisatie te verlaten. Hierbij komt wederom het gegeven of werknemers hun kwalificaties op de externe arbeidsmarkt kunnen verkopen, hetgeen bij organisatiespecifieke kwalificaties moeilijk zal zijn. Ritzen (1991) voegt de kosten van de transactiespecificiteit van kwalificaties en de 'normale' mobiliteitskosten (zoals verhuiskosten) samen tot de totale transactiekosten van mobiliteit. Deze totale transactiekosten van mobiliteit plus de vraag- en aanbodverhoudingen 
op de externe arbeidsmarkt zullen dus de beloning bepalen.

\section{Drie configuraties van arbeidsmarkten}

Vele auteurs onderscheiden drie of vier configuraties van arbeidsmarkten waarbij op basis van een aantal economische determinanten verschillende regels voor allocatie, beloning en scholing gelden. De naamgeving van deze configuraties varieert soms bij deze auteurs (bijvoorbeeld De Grip, 1987b; Ham, Paauwe \& Williams, 1988; Williamson, 1981 en Ouchi, 1979) en ook de relevante dimensies variëren soms enigszins. Wij zullen echter aansluiten bij De Grip (1987b) die de secundaire arbeidsmarkt, de interne arbeidsmarkt en de vakdeelmarkt onderscheidt.

De eerste configuratie is de secundaire arbeidsmarkt. De (neo)klassieke theorie met betrekking tot arbeidsmarkten beschouwt de arbeidsmarkt als een normale markt, waarbij allocatie (juiste man/vrouw op de juiste plaats) en prijsvorming (beloning) binnen een open en flexibele markt zorgen voor evenwicht. De enige relatie in ons 'human resource'-model die er dan feitelijk toe doet is die tussen beloning en externe mobiliteit. In het neoklassieke model wordt meestal uitgegaan van veronderstellingen zoals volledige informatie, waaronder meetbaarheid van de produktiviteit, elasticiteit van vraag en aanbod en homogeniteit van arbeid. Soms gaan deze veronderstellingen op en kan worden gesproken van een 'spot-market'. Williamson (1981) bijvoorbeeld spreekt van een spot-market als er sprake is van een geringe organisatiespecificiteit van menselijk kapitaal gecombineerd met een gemakkelijke meetbaarheid van de produktiviteit. De Grip (1987) noemt een aantal kenmerken van secundaire arbeidsmarkten, waaronder een laag functieniveau, het ontbreken van scholingsinvesteringen en de extreem hoge (externe) arbeidsmobiliteit.

Soms worden er echter allerlei 'marktimperfecties' in de theorie ingebracht. Enkele van deze marktimperfecties zijn al de revue gepasseerd. Dit zijn met name de elementen specifieke kwalificaties, interne mobiliteit, onmeetbaarheid van produktiviteit en immateriële beloning. Door de aanwezigheid van deze factoren zal de allocatie en prijsvorming niet geschieden conform de veronderstellingen van een open en flexibele arbeidsmarkt. De contouren van een interne arbeidsmarkt waar eigen spelregels gelden, zullen zich aftekenen. Naarmate specifieke training, interne mobiliteit, onmeetbaarheid van produktiviteit/menselijk kapitaal en immateriële beloning dominanter wordt in een organisatie zal het concept 'interne arbeidsmarkt' meer opgaan. Onder sommige omstandigheden kan een organisatie op rationele gronden besluiten om boven het marktloon te gaan zitten en misschien zelfs algemene training te verschaffen. Dit heeft alles te maken met het lange termijn perspectief betreffende de produktiviteit van de in dienst genomen werknemers. Doeringer \& Piore (1985) beschouwen de interne arbeidsmarkt als 'een administratieve eenheid waarin prijsvorming en allocatie gereguleerd worden door een set van 
administratieve regels en procedures'. De interne arbeidsmarkt moet volgens hen onderscheiden worden van de externe arbeidsmarkt, waar prijsvorming, allocatie en trainingbeslissingen beheerst worden door economische variabelen. Deze zienswijze over interne arbeidsmarkten is niet de onze. Ook de interne arbeidsmarkt wordt beheerst door economische variabelen. Er wordt dan echter een aantal assumpties van het klassieke model losgelaten door het introduceren van aannames als 'arbeid is niet homogeen', 'informatie over de produktiviteit is beperkt' en 'mobiliteit kan ook intern zijn'.

De derde configuratie is de vakdeelmarkt. Hieronder wordt verstaan de verzameling van externe arbeidsmarkten voor beroeps- of vakspecifiek geschoolde arbeidskrachten, die in verschillende bedrijven produktief kunnen worden ingezet. Deze arbeidskrachten beschikken over een algemene beroepsscholing, die in meerdere bedrijven of instellingen produktief kan worden aangewend. Van Hoof \& Dronkers (1980) spreken dan ook van vakdeelmarkten 'als het gaat om vakken als betrekkelijk homogene bundels van kwalificaties waardoor de bezitters van die kwalificaties in staat zijn ongeveer gelijksoortige arbeid in verschillende organisatie te verrichten'. Kortom, er is sprake van beroeps- of branchespecifieke kwalificaties en niet van organisatiespecifieke kwalificaties. Binnen deze vakdeelmarkten wordt nog wel onderscheid gemaakt tussen 'professional markets' en 'craft markets'. Tot de eerste groep rekent men beroepsgroepen als artsen, juristen, economen, architecten, e.d. en tot de tweede groep beroepen als bouwvakker, havenarbeider, chauffeur, kapper. (De Grip, 1987b). Vakdeelmarkten zijn niet alleen beroeps- maar ook branchegebonden. In figuur 2.2 in dit rapport zagen we een scatterdiagram van bedrijfsklassen die op een bepaalde wijze scoren op de dimensies 'gemiddeld opleidingsniveau' en 'percentage training'. In het kwadrant 'MAKE', kwamen we bedrijfsklassen tegen die gekenmerkt worden door een hoge proportie vereiste vaardigheden in tegenstelling tot kennis. Dit zijn 'craft-markets', zoals reparatiebedrijven (garages), de bouw, bouwinstallatiebedrijven en overige dienstverlening (kapperszaken). In het kwadrant 'BUY' daarentegen is vooral kennis (in tegenstelling tot vaardigheden) dominant. Hierbij valt te denken aan de bedrijfsklassen onderwijs, sociaal-culturele instellingen en luchtvaart. Dit zijn wellicht meer professionele markten. Volgens De Grip (1987b) kenmerken vakdeelmarkten zich door:

- een algemene beroepsscholing, in tegenstelling tot de bedrijfsspecifieke beroepsscholing die arbeidskrachten op een bedrijfsdeelmarkt kenmerkt;

- een relatief geringe binding met een bepaalde werkgever, tot uiting komend in een relatief hoge arbeidsmobiliteit;

- een hogere beloning dan voor secundaire marktfuncties.

De vakdeelmarkt wordt ook vaak in verband gebracht met Mintzberg's zogenaamde professionele bureaucratie (Schwan, 1993), waarbij de standaardisatie van kwalificaties een zeer belangrijk coördinatiemechanisme is. Bij kennis-gerelateerde beroepen en branches kan deze standaardisatie van kwalificaties via het reguliere 
onderwijssysteem gebeuren ("BUY'), terwijl bij vaardigheden-gerelateerde beroepen en branches additionele training nodig is ('MAKE').

\subsection{Conclusie en samenvatting}

In dit hoofdstuk is geprobeerd om op verschillende wijzen tegen training aan te kijken. In het begin van dit hoofdstuk zijn technologische en de marktontwikkelingen, maar ook institutionele en arbeidsmarktontwikkelingen besproken. Een organisatie is namelijk geen op-zich-zelf-staande entiteit, maar heeft te maken met omgevingsontwikkelingen. In kader 3.1 worden de belangrijkste externe factoren opgesomd en worden de hiervan verwachte gevolgen voor de training in bedrijven weergegeven.

Daarnaast kenmerkt een organisatie zich door haar eigen dynamiek en wetmatigheden. Hierbij zijn organisatiekenmerken zoals de omvang van de organisatie, de produktiestructuur, de organisatie van de arbeid en de organisatiecultuur van belang. De produktiviteit in een organisatie wordt bepaald door twee produktiefactoren, namelijk 'kapitaal' en 'arbeid'. De produktiefactor arbeid werd in dit hoofdstuk verder uitgewerkt in een economisch getint 'human resource'-model. De belangrijkste 'human-resource'-domeinen in dit model worden gevormd door vijf kernvariabelen, te weten produktiviteit, beoordeling, training, mobiliteit en beloning. De kernvariabelen zèlf en de relaties tussen de diverse kernvariabelen (de pijlen in het in figuur 3.2 weergegeven 'human resource'-model) werden beschreven en op basis hiervan werd een drietal arbeidsmarkt-configuraties afgeleid. In kader 3.2 wordt een en ander nog eens kort samengevat. In dit schema zijn de vijf 'human resource'-domeinen uitgezet tegen de drie onderscheiden configuraties. 
Kader 3.1

De invloed van omgevingsontwikkelingen

\begin{tabular}{|c|c|c|}
\hline Omgevingsontwikkelingen & Soort ontwikkelingen & Gevolgen \\
\hline Technologische ontwikkelingen & $\begin{array}{l}\text { - steeds sneller verlopende } \\
\text { technologische ontwikkelingen } \\
\text { - veranderende branche-en } \\
\text { beroepenstructuur } \\
\text { - upgrading van werkzaamheden } \\
\\
\text { - cyclisch verloop van inno- } \\
\text { vaties }\end{array}$ & $\begin{array}{l}\text { - hogere afschrijving } \\
\text { van menselijk kapitaal } \\
\text { - een hoger opleidings- } \\
\text { niveau en meer } \\
\text { algemeen aanwend- } \\
\text { baar menselijk kapitaal } \\
\text { vereist } \\
\text { - diverse kwalificatie- } \\
\text { gevolgen voor diverse } \\
\text { functies }\end{array}$ \\
\hline Marktontwikkelingen & $\begin{array}{l}\text { - kwaliteit \& flexibiliteit } \\
\text { wordt belangrijker }\end{array}$ & $\begin{array}{l}\text { - hoger vereist oplei- } \\
\text { dingsniveau } \\
\text { - flexibelere inzet van } \\
\text { menselijk kapitaal } \\
\text { - meer algemene vaar- } \\
\text { digheden zijn vereist }\end{array}$ \\
\hline & $\begin{array}{l}\text { - toenemende mondiale concur- } \\
\text { rentie }\end{array}$ & $\begin{array}{l}\text { - efficiënter menselijk- } \\
\text { kapitaalbeheer }\end{array}$ \\
\hline Institutionele ontwikkelingen & $\begin{array}{l}\text { - faciliterende i.p.v. sterk } \\
\text { subsidierende overheid } \\
\text { betreffende post- } \\
\text { initiële training }\end{array}$ & $\begin{array}{l}\text { - lagere trainingskosten } \\
\text { - grotere trainingsrisico's, } \\
\text { hogere beoordelings- } \\
\text { kosten voor de } \\
\text { concurrent van het } \\
\text { trainende bedrijf } \\
\text { - het trainingsrendement } \\
\text { wordt door de overheid } \\
\text { niet opgehoogd }\end{array}$ \\
\hline Arbeidsmarktontwikkelingen & $\begin{array}{l}\text { - hoge uitbreidingsvraag bij } \\
\text { hooggeschoold werk } \\
\text { - lage uitbreidingsvraag bij } \\
\text { laaggeschoold werk } \\
\text { - meer onderbenutting/over- } \\
\text { scholing } \\
\text { - vergrijzing en ontgroening } \\
\text { - grotere participatie van } \\
\text { vrouwen }\end{array}$ & $\begin{array}{l}\text { - hoger vereist } \\
\text { opleidingsniveau } \\
\\
\text { - minder behoefte aan } \\
\text { training } \\
\text { - kortere potentiële } \\
\text { terugverdientijd } \\
\text { - langere potentiële } \\
\text { terugverdientijd }\end{array}$ \\
\hline
\end{tabular}


Kader 3.2

Kenmerken van 'human resource'-domeinen voor drie configuraties

\begin{tabular}{|c|c|c|c|}
\hline $\begin{array}{l}\text { Human resource } \\
\text { domeinen }\end{array}$ & $\begin{array}{l}\text { Secundaire } \\
\text { arbeidsmarkt }\end{array}$ & $\begin{array}{l}\text { Configuraties } \\
\text { vakdeelmarkt }\end{array}$ & Interne arbeidsmarkt \\
\hline mobiliteit & $\begin{array}{l}\text { extern; } \\
\text { uitsluitend horizontaal }\end{array}$ & $\begin{array}{l}\text { extern; } \\
\text { branche- en beroeps- } \\
\text { gebonden; } \\
\text { vooral horizontaal }\end{array}$ & $\begin{array}{l}\text { intern; } \\
\text { vooral verticaal }\end{array}$ \\
\hline beoordeling & $\begin{array}{l}\text { produktiviteit en } \\
\text { kwalificaties zijn } \\
\text { gemakkelijk meetbaar }\end{array}$ & $\begin{array}{l}\text { produktiviteit en } \\
\text { kwalificaties zijn } \\
\text { gemakkelijk meetbaar }\end{array}$ & $\begin{array}{l}\text { produktiviteit en } \\
\text { kwalificaties zijn } \\
\text { moeilijk meetbaar }\end{array}$ \\
\hline training & afwezig & $\begin{array}{l}\text { beroeps- en branche } \\
\text { specifieke kwalificaties }\end{array}$ & $\begin{array}{l}\text { organisatie- } \\
\text { specifieke en soms } \\
\text { algemene kwalifica- } \\
\text { ties }\end{array}$ \\
\hline beloning & materiële beloning & $\begin{array}{l}\text { ook immateriële } \\
\text { beloning (arbeidsinhoud) }\end{array}$ & $\begin{array}{l}\text { ook immateriële } \\
\text { beloning (vastigheid, } \\
\text { status) }\end{array}$ \\
\hline produktiviteit & korte termijn & korte termijn & lange termijn \\
\hline
\end{tabular}


$\ldots \ldots$ 


\section{Training in de praktijk}

\subsection{Inleiding}

$\mathrm{Na}$ het tweede hoofdstuk 'Training in cijfers' en het derde hoofdstuk 'Training in de theorie' volgt nu het vierde hoofdstuk 'Training in de praktijk'. Het empirisch gedeelte van het onderzoek 'Costs and Benefits of Training' krijgt hierin zijn beslag. De structuur van dit hoofdstuk is als volgt. Allereerst wordt in deze inleidende paragraaf de organisatie, de opzet en de instrumenten van het empirisch gedeelte van het onderzoek besproken. Daarna komen de resultaten aan de orde. De resultaten van de cases in alle deelnemende landen zijn reeds verwoord in het eindrapport van het onderzoek dat aan de Europese Commissie werd uitgebracht (Lindley \& Hogarth, 1993). In paragraaf 4.2 wordt een samenvatting van dit rapport gegeven en worden enkele resultaten geaccentueerd. In paragraaf 4.3 worden de Nederlandse cases er nog eens apart uitgelicht en in relatie gebracht met het vorige hoofdstuk. Tot slot, sluit paragraaf 4.4 dit hoofdstuk af met enkele conclusies.

De doelstelling van het onderzoek was het in kaart brengen van de kosten en baten van bedrijfsopleidingen, in de context van het nationale onderwijssysteem en de specifieke arbeidsmarktsituatie. Aan het onderzoek is zowel een kwantitatieve als een kwalitatieve dimensie te onderscheiden. Enerzijds is een aantal kerngegevens verzameld over de kosten en baten van bedrijfsopleidingen. Anderzijds is getracht inzicht te krijgen in de visies en achtergronden betreffende het trainingsbeleid. Het kon bijvoorbeeld interessant zijn om te achterhalen hoe het opleidingsbeleid zich verhoudt tot de totale bedrijfsstrategie, of tot de technologische ontwikkeling, de veranderingen van de bedrijfsorganisatie, het wervingsbeleid, het doorstromingsbeleid etc.

Allereerst volgt enige informatie over het onderzoeksdesign. Zoals vermeld, waren zes landen uit de Europese unie bij het onderzoek betrokken. In deze zes landen werd telkens een viertal sectoren onderzocht. Deze sectoren waren:

- dienstverlening in telecommunicatie (NACE 79a);

- drukkerij en uitgeverij (NACE 473.1, 473.2, 474.4);

- fabricage van kantoormachines en elektrotechnische industrie (NACE 33, 34);

- sofwarehuizen en handelsbanken (NACE 839.2, 812).

In elke sector werden per land twee bedrijven geselecteerd. Het totale onderzoek in de Europese Unie omvatte dus 48 bedrijven, waarvan 8 in Nederland. Het doel van de casestudies was niet het vergelijken van het ene land met het andere land, maar het gebruikmaken van de 'experimental variation' tussen de zes landen (Lindley \& Hogarth, 1993). De genoemde vier sectoren waren zodanig geselecteerd dat verdere variatie werd verkregen in de factoren die mogelijkerwijs training(strate- 
gieën) beïnvloeden. Het betrof hierbij de factoren afzetmarktsituatie, externe arbeidsmarktcondities, technologische ontwikkelingen, structuur van de sector en organisatiestrategieën. Bij de selectie van bedrijven werd gezorgd voor een zekere geografische spreiding binnen elk land en een vertegenwoordiging van zowel kleinere als grotere bedrijven. Bedrijven die niets of nauwelijks iets aan training of trainingsbeleid deden, werden niet in het onderzoek betrokken. Het laatste leverde dus een 'selection bias' op. De kosten/baten-verhouding bij bedrijven die niet trainen zal uiteraard anders liggen dan de kosten/baten-verhouding bij bedrijven die wel trainen, ervan uitgaand dat beide categorieën bedrijven rationeel handelen. Dit probleem, tezamen met meetbaarheidsproblemen, met name aan de batenkant, leidde ertoe dat afgezien werd van een bedrijfseconomische calculatie van de kosten en baten van training.

Het voorgaande betekent dat de resultaten van dit onderzoek niet mogen worden gegeneraliseerd naar gehele sectoren noch naar landen. Ze hebben slechts indicatieve betekenis en de cases zijn slechts te gebruiken als praktijkvoorbeelden. Verder kunnen aan de hand van de ervaringen nieuwe probleemstellingen worden opgespoord. Er is gekozen voor de optie om training in al zijn facetten te beschouwen en, mede door de gebrekkige mogelijkheden voor meting, niet te reduceren tot een bedrijfseconomisch calculatieprobleem. Of beter verwoordt door Lindley \& Hogarth (1993):

'The notions of 'costs' and 'benefits' tend to convey the use of quantitative assessment methods as a priority. This has not been the approach of the present study. Rather, priority has been given to placing training decisions in their full context from the start, seeking to capture the nature of the training decision being taken, recognising the complete range of costs and benefits involved, but allowing for the fact that not all of them will be identified by the decision-maker or be given equal attention'.

$\mathrm{Na}$ deze schets van het onderzoeksdesign wordt nu ingegaan op de methode en de gebruikte instrumenten. Per bedrijf vond in het voorjaar van 1993 een interview plaats met een persoon die voor het opleidingsbeleid in het desbetreffende bedrijf verantwoordelijk was danwel een hoge positie binnen de opleidingsafdeling bekleedde. Verder werd op diverse manieren aanvullende informatie verzameld. In EU-verband was een aantal onderzoeksinstrumenten ontwikkeld. Deze instrumenten waren:

- een lijst met gewenste kerngegevens, waarop gegevens moesten worden ingevuld over de uitgaven aan bedrijfsopleidingen, de omzet van de vestiging, de hoeveelheid personeel, het verloop en nog enkele andere kerngegevens;

- een interview-leidraad met aandachtspunten voor het interview zoals de organisatiebeschrijving, marktontwikkelingen, kosten en baten van training, de opleiding 
van de opleiders etc.;

- een individuele vragenlijst die door zo'n veertig werknemers ingevuld zou moeten worden.

De nadruk van het onderzoek lag duidelijk op de eerste twee instrumenten. De individuele vragenlijst was bedoeld om een indicatie te krijgen van de houding van het personeel ten aanzien van opleidingen en trainingen. Verder is nog gebruik gemaakt van het jaarverslag of het sociaal jaarverslag van het bedrijf voor aanvullende gegevens en achtergrondinformatie.

Op basis van de verzamelde informatie werd voor elk bedrijf een verslag gemaakt. In de caseverslagen kwamen achtereenvolgens de volgende onderwerpen aan de orde:

- een organisatiebeschrijving;

- de ondernemingsactiviteiten;

- de arbeidsmarkt;

- het algemene personeelsbeleid;

- het opleidingsbeleid;

- de kosten en baten van opleidingen;

- de organisatie van de afdeling opleidingen;

- de externe opleidingen;

- een kenmerkende functie in het bedrijf;

- de inhoud van de opleidingen;

- de opleiding van de opleiders.

De caseverslagen werden eerst voorgelegd aan de geïnterviewden en daarna in de zomer van 1993 opgestuurd naar de twee onderzoekers van het coördinerende 'Institute for Employment Research (IER)' van de University of Warwick (GB). In het najaar van 1993 werden de bedrijven nog op een aantal dimensies en indicatoren nader getypeerd. Het IER heeft alle caseverslagen en alle typeringen verwerkt in hun eindverslag (Lindley \& Hogarth, 1993).

\subsection{Training in Europa}

In deze paragraaf wordt het rapport van Lindley \& Hogarth (1993) samengevat. Hierbij wordt de structuur van het hoofdstuk 'Training in de theorie' aangehouden. Dit wil zeggen eerst een hoofdindeling in training van buitenaf gezien en training van binnenuit gezien. Bij training van buitenaf gezien wordt een onderverdeling gemaakt naar soorten externe ontwikkelingen (bijvoorbeeld institutionele en technologische ontwikkelingen) en bij training van binnenuit gezien worden de verschillende relaties uit het eerder afgeleide 'human resource'-model beschreven. 
Training van buitenaf gezien

\section{Marktontwikkelingen}

Rekening houdend met het recente verleden en met de middellange-termijnverwachtingen zijn de sectoren - wat betreft de marktontwikkelingen - in drie groepen te onderscheiden:

- sectoren die te maken hebben met een achteruitgang in werkgelegenheid door een gebrekkige vraag (kantoormachines) of de introductie van nieuwe technologieën gecombineerd met sectorale rationalisatie (handelsbanken);

- sectoren die een min of meer stabiele werkgelegenheid hebben en waar de produktiviteit stijgt door het verbeteren van de produktieprocessen (drukkerij en uitgeverij);

- sectoren die een sterke afzetmarktontwikkeling te zien geven in combinatie met werkgelegenheidsgroei (softwarehuizen en telecommunicatie-dienstverlening).

De huidige afzetmarktontwikkelingen hebben drieërlei gevolg voor de vraag naar kwalificaties. Allereerst dient de concurrentiepositie te worden verbeterd in opkomende segmenten met een hoge toegevoegde waarde. Op de tweede plaats zullen afzetmarktontwikkelingen leiden tot de noodzaak tot het creëren van een flexibel werknemersbestand ten einde te kunnen reageren op veranderende marktomstandigheden. Tot slot zullen afzetmarktontwikkelingen leiden tot realisering van een hoog peil van kwaliteitscontrole in de produktie van goederen en diensten. Vooral in het bankwezen en in de telecommunicatie hebben afzetmarktontwikkelingen tot grote veranderingen in de vraag naar kwalificaties geleid. Liberalisering van de markten van financiële dienstverlening heeft handelsbanken - in het licht van verdergaande competitie - ertoe gedwongen hun produktaanbod te vergroten. In het bankwezen is sprake van een grote verschuiving van de beroepenstructuur in de richting van 'financial sales jobs'. Dit heeft geresulteerd in een veel grotere aandacht voor verkooptraining van het middenkader en een veel grotere aandacht voor onderhandelingsvaardigheden van het hogere kader. In de telecommunicatiesector heeft de integratie van computer- en telecommunicatietechnologie geleid tot vele, nieuwe produkten. Monopolistische en oligopolistische marktsituaties worden thans geconfronteerd met toenemende concurrentie. Dit dwingt hen tot het stellen van andere kwalificatie eisen.

\section{Technologische ontwikkelingen}

Méér technologie kan een vraag naar additionele training genereren, maar het kan ook een substituut zijn voor kwalificaties. Een bepaalde techniek of technologische toepassing kan in het ene geval leiden tot een hoger vereist niveau van vaardigheden en in het andere geval leiden tot een lager vereist niveau van vaardigheden. Zo 
is de telecommunicatiesector zeer dynamisch wat betreft technologische verandering. Training is hier daarom sterk georiënteerd op het verschaffen en onderhouden van technologische kennis en vaardigheden. Tegelijkertijd is er echter het besef dat een groter aantal doeleinden nagestreefd dient te worden dan louter het verhogen van technische competentie. Zo is in het Franse telecommunicatiebedrijf een beweging waar te nemen in de richting van minder technische en meer managementachtige trainingen voor hogere functies. Bovendien is in dit bedrijf een grotere mate van teamwork geïntroduceerd en staat een verbetering van de communicatieve vaardigheden van het management op het programma. In de sector drukkerij en uitgeverij zijn eveneens notoire voorbeelden te vinden van de implicaties van nieuwe technologieën. Zo is bij een Franse drukkerij van kranten de taak van het elektronisch opmaken van een pagina verhuist van de drukkers naar de journalisten. Technologie is wel van invloed op training, maar het is geen eenduidig causale relatie. Afzetmarktstrategieën veroorzaken tezamen met technologische ontwikkelingen veranderingen in de kwalificatiestructuur in een bedrijf.

\section{Arbeidsmarktontwikkelingen}

Het onderzoek naar de kosten en baten van training heeft plaatsgevonden tegen de achtergrond van een verdieping van de recessie en groeiende werkloosheid in de landen van de Europese Unie, hetgeen ongetwijfeld de attitudes betreffende de rol en de plaats van training heeft beïnvloed. In sommige gevallen heeft de recessie geleid tot vermindering van de werving, met daarmee duidelijke gevolgen voor de training van nieuwkomers. Trainingsbudgetten zijn onder druk komen te staan, daar waar slechtere winstmarges hebben geleid tot bezuinigingsrondes. In enkele cases heeft de recessie echter geleid tot een hogere status van training en een hogere status van het beroepsonderwijs. Bij deze bedrijven werd training juist opgevat als een middel om uit het dal te geraken.

De invloed van de recessie op de werving en selectie is drievoudig:

- een reductie van het werven van leerlingen en ervaren staf, soms verbonden met een inkrimping van het personeelsbestand;

- een toename van de mogelijkheden om volledig getraind of ervaren personeel te rekruteren op de arbeidsmarkt;

- het beschikbaar komen van een grotere pool van goed gekwalificeerde, jonge leerlingen.

Vrijwel alle bedrijven waren tevreden over het onderwijsniveau van de nieuwe toetreders op de arbeidsmarkt. Er is daarin geen nationaal of sectoraal patroon te herkennen noch komt een gedifferentieerd beeld naar organisatiegrootte of lokale arbeidsmarktcondities naar voren. Ook ten aanzien van de hoger opgeleiden is men 
in zijn algemeenheid tevreden over het niveau. Wat betreft de vereiste kwalificaties was er eveneens behoorlijke overeenstemming in antwoorden te constateren. Alle bedrijven benadrukten het belang van basisvaardigheden in rekenen, taal en sociale en communicatieve vaardigheden. De behoefte aan technische vaardigheden was meer afhankelijk van de omstandigheden, maar ook hier valt geen systematisch sectoraal of nationaal patroon te ontwaren. De algehele indruk bestaat dat de onderzochte bedrijven geen problemen ervaren in het werven van personen met een adequate onderwijsachtergrond.

\section{Institutionele ontwikkelingen}

Verschillende Europese landen hebben recentelijk een brede herbezinning gehad op hun onderwijssysteem met speciale aandacht voor de aansluiting tussen onderwijs en arbeidsmarkt. In Nederland heeft de Commissie Rauwenhoff de discussie over deze aansluiting gestimuleerd. In lerland is een 'Green Paper' verschenen, met het doel het gehele onderwijssysteem te veranderen. In Spanje heeft de nieuwe Onderwijswet tot doel het initiële beroepsonderwijs dichter bij de arbeidsmarkt te brengen. Hierbij heeft men de sociale partners (werkgevers en werknemers) een belangrijke rol toebedeeld. Ook in Frankrijk is een nauwere relatie aangebracht tussen de scholen en het bedrijfsleven, ofschoon in een recent rapport van het 'Conseil du Patronnat Français' het functioneren van het onderwijssysteem nog sterk wordt bekritiseerd. Men stelde dat het onderwijssysteem niet weet, hoe het moet reageren op de behoeften van het bedrijfsleven.

Dit in tegenstelling tot Duitsland, waar de onderwijsontwikkelingen niet zo zeer gevoed worden door mismatches tussen de klaarblijkelijke behoeften van de arbeidsmarkt en het falen van het onderwijssysteem. De belangrijkste discussie in Duitsland betrof het gezamenlijke antwoord van de onderwijswereld en het bedrijfsleven op de stijging van de vereiste onderwijsniveaus en de daaraan gekoppelde behoefte om de onderwijs-, training- en kwalificatiestructuren hierop aan te passen. In Duitsland zijn evenwel geen fundamentele wijzigingen in het onderwijssysteem aangebracht. Het Duits beroepsonderwijs kan nog steeds gekarakteriseerd worden als een corporatistisch, tri-partite systeem (Betrieb--Verband--Staat). Alleen als de markt faalt, grijpt de overheid in (bijvoorbeeld bij onderwijs voor gehandicapten). Een belangrijk onderscheidend kenmerk van het Duitse systeem is de samenwerking tussen de Kamers van Koophandel, de werkgeversorganisaties en de vakbonden.

Het gaat te ver om elk land uitvoerig te behandelen. Er kan in ieder geval wel worden geconcludeerd dat er in alle landen hervormingen aan de gang zijn om de behoeften van het bedrijfsleven en het onderwijssysteem beter op elkaar af te stemmen. De richting van deze hervormingen wordt gedeeltelijk gedetermineerd 
door de historische ontwikkeling van het onderwijssysteem in elk land.

Training van binnenuit gezien

\section{Organisatiekenmerken}

Met name in de cases uit de dienstverlenende sector bleek het belang van organisatiekenmerken. Produktiviteitsverbeteringen zijn in de dienstverlenende sector tot stand gebracht door middel van managementconcepten die voorheen uitsluitend in de industrie voorkwamen, zoals het creëren van platte organisaties en 'total quality management'. Als voorbeeld kan een Britse bank dienen. Een pas afgestudeerde, mannelijke academicus van 18 jaar oud doorliep in deze bank voorheen een uitgestippeld carrièrepad met zes stappen. Elke carrièrestap ging gepaard met een set van cursussen. De set met cursussen moest met succes afgerond worden, alvorens de volgende stap gezet kon worden. Promotieladders waren zeer duidelijk waarneembaar voor het management (Trainee Cashier---> Cashier---> Supervisor---> Pre-management position---> Branche Management---> Area Manager----> Divisional Manager). Dit is nu veranderd. Verschillende hiërarchische lagen zijn verdwenen en de mix van cursussen is in elke fase veranderd. $\mathrm{Er}$ is tegenwoordig een bredere set van vaardigheden vereist en de noodzaak tot verdieping van vaardigheden per specifiek onderdeel, is verdwenen. Er zijn nu ook laterale carrièrestappen mogelijk, bijvoorbeeld van 'banking services' naar 'financial sales', ten einde een bredere set van ervaringen op te bouwen. De individuele werknemer dient nu zelf verantwoordelijkheid te nemen voor het identificeren van trainingsbehoeften, in termen van zowel planning als financieën. Organisatiekenmerken zijn dus niet alleen bepalend voor de omvang van de trainingsbehoefte maar tevens voor het type en de wijze van identificering van de trainingsbehoefte en voor het mobiliteitspatroon.

\section{Training en produktiviteit}

In het eindrapport van Lindley \& Hogarth (1993) wordt onderscheid gemaakt tussen harde en zachte kengetallen betreffende de baten van training. Onder 'harde kengetallen' worden kwantitatieve metingen verstaan van de invloed van training op een aantal produktiviteits-indicatoren. Voor algemene managementtraining is deze invloed nauwelijks te identificeren, maar voor technische vaardigheidstraining is het theoretisch mogelijk deze informatie te achterhalen. In de praktijk verzamelen echter weinig bedrijven de benodigde data om een kosten-baten analyse te kunnen uitvoeren. In de elektronicasector komt men soms calculaties tegen en dan vooral ten aanzien van het initiële trainingsprogramma. Bijvoorbeeld in een Duitse fabriek in de elektrotechnische industrie heeft een leerlingverkoper in het eerste dienstjaar $105 \%$ van het salaris als effectieve output, in het tweede jaar $110 \%$ en in het derde 
jaar $120 \%$. De produktiviteit in relatie tot de loonkosten stijgt dus in de eerste drie jaar. Een ander voorbeeld is ontleend aan een Britse elektronica fabriek. Deze fabriek heeft een 'zero-defects' produktieplan. Geen van de assemblagemedewerkers was echter bekend met het zero-defect concept. Het bedrijf besloot totale kwaliteitsmanagement in te voeren en een trainingsplan voor elke werknemer te maken. De daaruit volgende cursus over zero-defects duurde zes keer anderhalf uur en werd gegeven in groepen van tien werknemers. Het doel van de cursus was het benadrukken van het belang van een laag foutenpercentage, wat zou leiden tot kostenbesparingen. $\mathrm{Na}$ een pilotproject in de draagbare radio-divisie van de fabriek waren er inderdaad enige bewijzen dat het foutenpercentage was gedaald. Het was nog niet bekend of er sprake was van een zogenaamd 'halo-effect', waarbij na een relatief korte periode het positieve effect weer verdwijnt. Een verdere aanwijzing voor de effectiviteit van de training is het feit dat de directeur van het bedrijf nu alle 630 werknemers een dergelijke cursus over zero-defects wil geven.

Bovendien worden in het rapport van Lindley en Hogarth nog enkele 'zachte' kengetallen betreffende de baten van training genoemd. Wederom wordt de Duitse fabriek in de elektrotechnische industrie als voorbeeld aangehaald. De volgende baten werden genoemd:

- leerlingen die worden opgeleid door het bedrijf zelf, integreren sneller in de organisatie;

- continue training verschaft het bedrijf gemotiveerd en flexibel personeel;

- werknemers verwachten zich bij het bedrijf verder te kunnen ontwikkelen. Een goede werkgever moet deze verwachting daarom waarmaken, niet alleen om goed gekwalificeerd personeel te kunnen werven maar ook om te kunnen behouden;

- gedurende recessies kunnen goed opgeleide werknemers gemakkelijker overgeplaatst worden, hetgeen ontslagen voorkomt en de naam van het bedrijf hoog houdt.

Als het gaat om alle casestudies tezamen dan kwam telkens min of meer bovengenoemde lijst van baten naar voren, ofschoon de laatste categorie baten typerend was voor landen met een hoge mate van ontslagbescherming.

Voor de meeste organisaties die in het onderzoek zijn betrokken, werd een formele kosten- en baten-analyse van training - in termen van concurrentiekracht en produktiviteit - niet noodzakelijk geacht. Men vertrouwt er gewoonweg op dat training de bedrijfsproduktiviteit positief zal beïnvloeden. Het management schijnt van mening te zijn dat een grote inspanning voor het uitvoeren van een kosten/baten-analyse overbodig is. Zij vinden het belangrijker een goed begrip te krijgen van hoe produktmarktcombinaties zich ontwikkelen en welke consequenties dat zal hebben voor de 'human resource development'. 


\section{Produktiviteit en beoordeling}

De beoordeling van de effecten van training kan op velerlei manieren gebeuren. Op de eerste plaats zijn er natuurlijk altijd de informele percepties van trainingsmanagers en afdelingsmanagers. De waarde van deze informele percepties moet niet worden onderschat. Wat betreft de iets formelere evaluatie-instrumenten zijn de meest voorkomende vormen bij het evalueren van een trainingscursus:

- individuele vragenlijsten na afloop van de cursus waarbij een subjectief oordeel van het individu over de cursus wordt gevraagd;

- een beperkte 'follow-up';

- een jaarlijks beoordelings- of functioneringsgesprek.

Aan het eind van een off-the-job training is het gebruikelijk dat de trainingsafdeling een kort evaluatieformulier voorlegt aan de cursisten. Dit gaat dan over de inhoud van de cursus, de tutor en het nut voor de eigen werkzaamheden. Deze formulieren worden ook wel 'happy sheets' genoemd en geven dus een (te positieve) subjectieve indruk van de baten van een opleiding. Meestal geven deze formulieren wel een goed beeld van de kwaliteit van de cursus, maar is het instrument ongeschikt voor het inschatten van de waarde van de cursus voor de uitvoering van de dagelijkse werkzaamheden.

Bij het tweede instrument wordt de cursist na afloop van de cursus verder gevolgd in de praktijk. In een Duitse en een Britse bank werden de cursisten in het natraject min of meer gedwongen de opgedane vaardigheden in praktijk te brengen. In een Nederlandse bank werd overigens geconstateerd dat de vaardigheden nauwelijks in praktijk werden gebracht, maar er werd verder niets met deze informatie gedaan.

De derde evaluatiemethode is het (half-)jaarlijkse beoordelings- of functioneringsgesprek, een methode die vooral bij hogere functies populair is. Naast andere aangelegenheden wordt in zo'n gesprek meestal de doorlopen training besproken, met meestal daaraan gekoppeld de consequenties voor het functioneren. Sommige bedrijven gaan bij de evaluatie nog een stapje verder door vóóraf vragenlijsten te laten invullen. Zo verkrijgt men een voor- en nameting, die door de lijnmanager kan worden geverifieerd om de betrouwbaarheid van de uitkomsten te vergroten. Het merendeel van de opleidingsfunctionarissen ervoer dit als een effectieve evaluatiemethode, ofschoon het wel de nodige middelen (geld, tijd) vereist.

\section{Training en beoordeling}

In de vorige paragraaf ging het om de beoordeling van de produktiviteit naar aanleiding van een reeds afgeronde cursus. Dit loopt niet altijd parallel met het inventariseren van nieuwe opleidingsbehoeften. In zijn algemeenheid zijn er weinig 
bedrijven - met uitzondering van het bankwezen en telecommunicatiebedrijven - die een formele analyse van de opleidingsbehoeften uitvoeren. In vrijwel alle cases viel training onder de verantwoordelijkheid van het lijnmanagement. Er zijn weinig bewijzen voor de notie dat de individuele verantwoordelijkheid van de werknemer een belangrijke factor is voor het identificeren van opleidingsbehoeften. Meestal was er geen op het individu toegespitst trainingsplan. In de praktijk is het trainingsprogramma meestal gekoppeld aan het doorlopen van de hiërarchische stadia in het bedrijf.

\section{Training en beloning}

In het eindrapport van Lindley \& Hogarth wordt nauwelijks expliciet ingegaan op de relatie tussen training en beloning. Wel wordt bij de baten van training regelmatig gewezen op de indirecte verhoging van de produktiviteit door middel van training. Training zal immers leiden tot een hogere motivatie en satisfactie van werknemers, hetgeen weer leidt tot een hogere produktiviteit (in zowel kwalitatieve als kwantitatieve zin).

Daarnaast speelt uiteraard de vraag of training door werknemers als een 'fringe benefit' wordt ervaren en of de opleidingskosten (gedeeltelijk) in mindering worden gebracht op hun beloning. In het Nederlands gedeelte over training in de praktijk proberen we hierop wat meer zicht te krijgen.

\section{Trainingsbeleid}

In het eindrapport van Lindley \& Hogarth wordt onderscheid gemaakt tussen 'targeted training policies' en de 'education for all'-benadering. Bij een 'targeted policy' is training direct gericht op het vervullen van huidige of toekomstige bedrijfsdoelen. Daartegenover staat de 'education for all'-benadering waarbij training - in een breder verband - baten zou kunnen opleveren voor het bedrijf. In de laatste benadering is een verbetering van de kwaliteit van het werknemersbestand in ieder geval goed voor het bedrijf, omdat het namelijk baten opbrengt die nooit van te voren gepland kunnen worden. Deze benadering trotseert hiermee 'human resource strategen' die te veel geloof hebben in het identificeren van concrete opleidingsbehoeften. Als voorbeeld kan een Britse Elektronica-fabriek fungeren. Het hier gevoerde 'education for all'-beleid is een onderdeel van een algeheel welzijnsprogramma voor het personeel. Het bedrijf zal alle cursussen betalen en zal voor alle cursussen vrije tijd verschaffen, indien zij zowel in het belang van de organisatie als in het belang van de werknemer zijn. Hierbij wordt het 'belang voor de organisatie' tamelijk losjes geïnterpreteerd, omdat een assemblage-werknemer niet in aanmerking zou komen voor een cursus tuinieren, maar wel voor een vreemde talencursus, al is er nauwelijks de verwachting dat dit in het belang is van de organisatie. 
Desalniettemin komt toch in de meeste bedrijven naar voren dat de voornaamste beweegreden voor training de afstemming met de bedrijfsdoelen is. Training heeft vooral een functie in de ontwikkeling van de organisatie. Relatief weinig onderzochte bedrijven zijn genoodzaakt te trainen vanwege bestaande leemtes op de externe arbeidsmarkt. In principe zijn er wel ervaren krachten in te huren, maar er zijn kennelijk additionele redenen om toch zèlf zorg te dragen voor de training. Alleen in telecommunicatiebedrijven en het bankwezen komt het wel eens voor dat men traint vanwege een gebrek aan extern aanbod. Dit geldt duidelijk niet voor de onderzochte Spaanse bank die onomwonden stelt: training is goedkoper dan het inhuren van ervaren professionals.

\subsection{Training in Nederland}

Zoals vermeld, zijn in Nederland 8 cases onderzocht, verdeeld over 4 sectoren. Vanwege de gewenste anonomiteit van de bedrijven is gekozen voor 'fake'-namen. In tabel 4.1 staan de acht bedrijven opgesomd. In de diverse kaders komen de bedrijven uitgebreid aan de orde.

Tabel 4.1

De acht onderzochte bedrijven in Nederland

\begin{tabular}{lll}
\hline Sector & Bedrijf & Kader \\
\hline $\begin{array}{lll}\text { Dienstverlening in } \\
\text { telecommunicatie }\end{array}$ & TELEC & $4.1,4.9$ \\
$\begin{array}{ll}\text { Drukkerij en } \\
\text { uitgeverij }\end{array}$ & SWITCH & 4.3 \\
$\begin{array}{l}\text { Fabricage van kantoor- } \\
\text { machines en elektrotechnische } \\
\text { industrie }\end{array}$ & PRESS & $4.4,4.7$ \\
Software huizen en & OFFISEC & 4.6 \\
handelsbanken & MOSSO & 4.2 \\
& & 4.5 \\
\hline
\end{tabular}

Training van buitenaf gezien

\section{Marktontwikkelingen}

In vrijwel alle cases komt naar voren dat afzetmarktontwikkelingen belangrijk zijn voor het voortbestaan van organisaties en dat zij leiden tot wijzigingen van de organisatie, het personeelsbeleid en van het opleidingsbeleid. Onderstaande TELEC-case toont aan dat marktontwikkelingen gevolgen hebben voor de organisatie van de arbeid en daarmee ook voor de training van werknemers. Liberalisering 
en internationalisering vormden een belangrijke drijfveer voor de ombouw van een min of meer bureaucratische overheidsorganisatie tot een commercieel opererend bedrijf in een complexe omgeving. De directeur van TELEC noemt dit 'het kantelen van de organisatie': het is niet meer 'top' en 'down' maar 'voorkant' en 'achterkant'. De voorkant zorgt ervoor dat de klanten op het juiste tijdstip bediend worden met de juiste produkten, terwijl de 'achterkant' alleen maar bestaansrecht heeft, vanwege de ondersteuning aan de 'voorkant' (zie kader 4.1). Binnen deze organisatieveranderingen passen andere werkrollen en zogenaamde standaardklantprocessen, hetgeen een grote leernoodzaak voor TELEC oplevert.

Kader 4.1

De invloed van marktontwikkelingen

\section{CASE: TELEC}

TELEC is een bedrijf dat binnen en buiten de aan hem verleende concessies aan zowel de zakelijke als de particuliere markt een compleet pakket hoogwaardige produkten en diensten levert, geconcentreerd rond het nationaal en internationaal transport van informatie, goederen en waarden. In 1989 is een verzelfstandiging ingezet, waardoor het bedrijf nu tot de private sector behoort.

TELEC verandert in snel tempo. Hierbij spelen twee ontwikkelingen een grote rol: liberalisering en internationalisering. Door het wegvallen van de interne Europese grenzen met ingang van 1 januari 1993, zal de markt voor postaal verkeer en zeker de markt voor telecommunicatie, opener en vrijer worden. Het ziet ernaar uit dat rond de eeuwwisseling zelfs volledige liberalisering van de totale telecommunicatiemarkt in het vizier komt. Hierdoor zal de concurrentie toenemen en zullen er marktaandelen verloren gaan. De liberalisering en internationalisering brengen echter ook kansen en uitdagingen met zich mee.

Kern van de ingrijpende reorganisatie van 1993 is een herschikking van alle activiteiten met als doel de organisatie dichter bij de klant te brengen, verhoging van de geboden kwaliteit en structurele vereenvoudiging van processen. De vorming van de telecomregio's heeft ertoe geleid dat ruim 9.000 mensen een nieuwe functie hebben gekregen. Op dit moment levert de reorganisatie, de nieuwe standaardklantprocessen en de nieuwe werkrollen binnen de standaardklantprocessen de grootste leernoodzaak op. Bovendien is aan het op de markt brengen van nieuwe produkten en diensten een leernoodzaak verbonden.

Er zijn ook wel andere voorbeelden van de importantie van marktontwikkelingen voorhanden, zoals bij het softwarehuis SOFTWARE. Vroeger was er in dat bedrijf vooral de 'gemakkelijke automatisering', oftewel het feitelijke programmeerwerk. Tegenwoordig is informatica geen wondermiddel meer en hebben bedrijven zèlf al de nodige kennis opgedaan. De lijnmanagers kunnen hierdoor veel informaticabeslissingen zelf nemen. Naarmate het niveau van de gesprekspartner in het cliëntbedrijf toeneemt, de 'moeilijke automatisering' (zoals managementinformatiesystemen en 'decision support'-systemen) de overhand krijgt en naarmate de kosten en baten van automatisering moeilijker meetbaar zijn, is het noodzaak om meer aandacht te besteden aan de branche- en bedrijfsspecifieke achtergronden 
van een automatiseringsprobleem. Vandaar dat men een strategische ontwikkeling doormaakt van informatica-consultancy naar business-consultancy.

Het ontwerpen of veranderen van organisaties met behulp van informatica, is tegenwoordig dominant. Hiervoor is veel meer kennis van de desbetreffende branche en het desbetreffende bedrijf nodig. In zowel het wervings- als het opleidingsbeleid wordt hierop ingesprongen, omdat de klanten nu eenmaal bepaalde (branchespecifieke) expertise en vaardigheden van de medewerkers verwachten.

\section{Technologische ontwikkelingen}

Er zijn bedrijven die meer en die minder technologisch gedetermineerd zijn. Maar zelfs binnen een bedrijf kunnen er grote verschillen zijn. Bij het bedrijf PRESS ademen de afdelingen drukkerij en zetterij een heel andere sfeer uit, dan de afdelingen redactie en commercie. Terwijl bijvoorbeeld in de divisies redactie en commercie de open en mensgerichte leiderschapstijl dominant is, wordt in het technische bedrijf toch vooral een sturende en taakgerichte leiderschapstijl wenselijk geacht.

Een bedrijf dat duidelijk technologisch gedetermineerd is, is OFFITEC. Er worden wel pogingen gedaan om dit te veranderen, door de verkoop en service voor het grootste gedeelte via de eigen bedrijven te laten plaatsvinden en door een directe relatie met de klant op te bouwen, maar het blijft toch in eerste instantie een technisch georiënteerd bedrijf. Nu er recentelijk wordt gesneden in de opleidingsuitgaven gaan eerst de management-opleidingen onder het mes en worden de technische opleidingen grotendeels gespaard (zie kader 4.2). Dit heeft overigens ook met de kosten/baten-verhouding en de meetbaarheid van de effecten van opleidingen te maken. Bij management-opleidingen is het immers nog maar de vraag wat het oplevert, terwijl technische opleidingen een duidelijk herkenbare functie hebben.

Ook bij de andere onderzochte bedrijven is het belang van technologische ontwikkelingen duidelijk te zien. Bij het bedrijf BANCO valt bijvoorbeeld te denken aan de voortschrijdende automatisering en aan de betaalautomaten, hetgeen een stijging van het gemiddelde opleidingsniveau van het personeel teweegbrengt en nieuwe trainingsbehoeftes creëert. Bij het bedrijf SWITCH wordt de behoefte aan opleidingen eveneens grotendeels bepaald door technologische ontwikkelingen. Het is een innovatief bedrijf, waar gewoonweg veel nieuwe technieken geleerd moeten worden. Bij PRESS zal in de toekomst wellicht bij de zetterij de indeling in subafdelingen (bijvoorbeeld zetselproduktie, zetselverwerking en reproduktie) komen te vervallen. De organisatie zal in de toekomst in de richting van geïntegreerde, produktgebonden werkgroepen veranderen, hetgeen geheel tegengesteld is aan het 
traditionele grafische ambacht, waarin juist specialisatie een belangrijk kenmerk was. Het is evenwel nog niet goed voorstelbaar, dat er ook integratie van taken of functies, multi-inzetbaarheid en doorstroming tussen de afdelingen zal ontstaan. Een drukker kan namelijk niet om- of bijgeschoold worden tot zetter en een zetter kan niet om- of bijgeschoold worden tot drukker. Deze beroepen liggen hiervoor te ver uit elkaar.

Kader 4.2

De invloed van technologische ontwikkelingen

\section{CASE: OFFITEC}

De strategie van OFFITEC is gelegen in de grote aandacht voor sterk marktgerichte onderzoeks- en ontwikkelingsactiviteiten. Jaarlijks wordt circa $7 \%$ van de omzet in onderzoek en ontwikkeling geïnvesteerd. In 1992 waren de uitgaven voor onderzoek en ontwikkeling meer dan 180 miljoen gulden.

We noemen een aantal belangrijke ontwikkelingen in de tekenkamermarkt. Op de eerste plaats maakt de zogenaamde diazotechniek gaandeweg steeds meer plaats voor plain-paper systemen. Deze plain-paper systemen zijn in principe gelijk aan de kopieersystemen voor de kantooromgeving. Een andere belangrijke ontwikkeling is de voortschrijdende digitalisering, met daaraan verbonden de mogelijkheden van Computer Aided Design. Een derde belangrijke ontwikkeling is de opkomst van kleurenkopieerapparaten en kleurenplotters. Als gevolg van bovenstaande ontwikkelingen wordt op langere termijn een convergentie tussen kopiëren en plotten voorzien.

De oorzaken van de leernoodzaak zijn vooral gelegen in technologische ontwikkelingen. Allereerst dwingen nieuwe werkmethoden en nieuwe technieken tot de behoefte aan flexibele werknemers. Vandaar dat medewerkers regelmatig andere opdrachten of projecten krijgen, zodat men in diverse werkplekken kennis en ervaring kan opdoen. Van het totale leren wordt ongeveer $90 \%$ aan on-the-job-training toegeschreven. Slechts $10 \%$ kan er door het volgen van bedrijfsopleidingen e.d. aan toegevoegd worden. Bij het volgen van cursussen, voerden de technisch-georiënteerde cursussen duidelijk de boventoon. Aangezien OFFITEC een technologisch vooruitstrevend bedrijf is, zijn onder andere elektronica, werktuigbouwkunde, software-engineering, automatisering en bedrijfskundige opleidingen erg dominant in het opleidingsaanbod. De managementopleidingen staan daarentegen onder druk en de centrale expertise op dit gebied zal worden beëindigd.

Het bedrijf PRESS laat zien dat technologische ontwikkelingen schoksgewijs kunnen verlopen. Dit bedrijf koopt ongeveer één keer in de tien jaar een nieuwe pers. Het laatste persenplan heeft in drie jaar tijd 1,6 miljoen gulden aan trainingskosten gevergd, waarvan 0,7 miljoen gulden betrekking heeft op de doorbetaling van de salarissen tijdens de stageperiodes. Dit specifieke project betrof 55 drukkers, die in vier groepen, ieder gedurende één jaar, opgeleid en getraind werden. Zij liepen allen 3 maanden stage bij andere bedrijven en namen deel aan de cursus offsetrotatie drukker bij het grafisch opleidingsinstituut te Veenendaal. Kortom, de komst van de nieuwe pers ging gepaard met een forse verhoging van de opleidingintensiteit, die naar verloop van tijd weer zal afnemen, zodra de nieuwe pers goed functioneert. Aangezien technologische innovaties hun eigen dynamiek hebben, 
zullen ook de hieruit voortvloeiende opleidingsbehoeftes een dynamisch karakter hebben.

\section{Arbeidsmarktontwikkelingen}

Uit de casestudies komt naar voren dat arbeidsmarktontwikkelingen nauwelijks een rol spelen bij het opleidingsbeleid. Over het algemeen is men best tevreden over het aanbod van goed, gekwalificeerd personeel. Dit kan natuurlijk ook te maken hebben met het tijdstip van het onderzoek (voorjaar 1993) waarin de economische recessie hevig was en er sprake was van een aanbodoverschot op de arbeidsmarkt. Toch worden zo her en der specifieke tekorten c.q. kraptes op de arbeidsmarkt gemeld. In kader 4.3 wordt SWITCH behandeld en daarin blijkt dat men een tekort ervaart aan vrouwelijke technici, senior commerciële functies, en schoolverlaters met de opleiding technische bedrijfskunde of anderszins technisch opgeleide schoolverlaters met enige commerciële bagage.

Bij het bedrijf MOSSO bestaan er tekorten op de arbeidsmarkt voor heel specifiek technisch geschoolden, met name in de specialismen hoogfrequent-technologie en Integrated Circuit (IC)-technologie. De genoemde specialismen treft men aan bij de Technische Universiteiten, in de afstudeerrichtingen chemische technologie, natuurkunde en elektrotechniek. Al vele jaren bestaat er een tekort aan deze categorieën afgestudeerden. Dit heeft tot gevolg dat sommige vacatures bij MOSSO al anderhalf jaar lang niet vervuld zijn. Verder zijn MTS-ers niet in ruime mate voorradig op de externe arbeidsmarkt. MOSSO lost dit probleem op door 'oeverloos te werven'. Men steekt veel energie in de contacten met de Technische Universiteiten, men haalt vele stagiaires in huis en men probeert zich zo goed mogelijk op de externe arbeidsmarkt te profileren.

Bij het bedrijf SOFTWARE is, zoals reeds gemeld, sprake van een verschuiving van informatica-consultancy naar business-consultancy. Bij de werving wordt hier- mee langzamerhand meer rekening gehouden. Naast het aantrekken van schoolverlaters zullen namelijk ook ervaren, oudere mensen aangetrokken worden met een gedegen branche- of bedrijfsspecifieke achtergrond (bijvoorbeeld ex-bankdirecteuren). Deze mensen zijn veel schaarser op de arbeidsmarkt.

TELEC constateert nauwelijks schaarste op de arbeidsmarkt. De gewenste rekruten zijn voor bijna alle personele categorieën of deelmarkten in ruime mate voorradig. Alleen voor marketing- en sales-functies is de druk op de arbeidsmarkt merkbaar. In de toekomst zou er op de externe arbeidsmarkt mogelijkerwijs een tekort aan MTSers kunnen ontstaan. Het betreft dan met name de MTS-richting Elektrotechniek. 
Kader 4.3

De invloed van arbeidsmarktontwikkelingen

\section{CASE: SWITCH}

De werkgelegenheid bij SWITCH is tussen begin 1992 (4211) en eind 1992 (3927) met 284 mensen $(6,7 \%)$ afgenomen. In zijn algemeenheid worden derhalve geen problemen in het rekruteren van arbeidskrachten gesignaleerd. Hierbij wordt echter een drietal kanttekeningen geplaatst. Op de eerste plaats is het moeilijk om vrouwelijke technici te werven, aangezien deze nauwelijks voorradig zijn op de externe arbeidsmarkt. Ten tweede kunnen erg specifieke functies tot een moeizame vacaturevervulling leiden. Het gaat dan bijvoorbeeld om meer senior commerciële functies, die veel kennis en ervaring vereisen. Op de derde plaats is er een toenemende behoefte bij SWITCH aan TU-ers of HTS-ers met enige commerciële kennis en schoolverlaters met een afgeronde opleiding technische bedrijfskunde. SWITCH is dus op zoek naar mensen met een gedegen technische achtergrond, die ook nog over de rand van hun eigen vakgebied kunnen kijken.

In geen van de bovengenoemde voorbeelden leidden eventuele tekorten tot bij- of omscholing van het zittende personeel. Het lijkt erop dat door middel van training wel iets bij te schaven valt, maar dat bij echte omvangrijke discrepanties training niet het geëigende middel is.

\section{Institutionele ontwikkelingen}

Bij institutionele ontwikkelingen gaat het onder meer om veranderingen in het reguliere onderwijssysteem en ontwikkelingen in het aanbod van opleidingen. Men constateert bij OFFITEC dat er ontzettend veel aanbod van externe opleidingen aanwezig is. Naar hun schatting zijn er in Nederland 1300 verschillende opleidingsinstituten. De informatieverstrekking over dit aanbod laat echter veel te wensen over. Het $\mathrm{CEDEO}^{8}$ doet iets op dit gebied, maar dit wordt niet als een succesvolle coördinatie beschouwd. Dit is vooral voor het midden- en kleinbedrijf problematisch, omdat zij niet meer weten wat er precies op de opleidingsmarkt te koop is. Bij OFFITEC wordt dus gesteld dat er weliswaar een groot opleidingsaanbod is, maar dat de opleidingsmarkt erg ondoorzichtig is.

Bij BANCO is een ander geluid te horen. Daar vindt men dat sommige cursussen of opleidingen vrijwel niet verkrijgbaar zijn bij externe instituten. Dit is in het midden van de jaren ' 80 iets verbeterd, met name door de komst van de studierichting bank- en verzekeringsleer op $\mathrm{HBO}$ - en WO-niveau en door de komst van $\mathrm{ECABO}^{9}$ op MBO-niveau. Uit het laatste blijkt de substitueerbaarheid van het reguliere

8. De stichting CEDEO is het centrum voor documentatie en voorlichting over bedrijfsexterne opleidingen.

9. Het ECABO is een landelijk orgaan voor het leerlingwezen voor opleidingen die zijn gericht op de economische en administratieve beroepen. 
onderwijs en de training van werkenden bij bedrijven.

Bij PRESS blijkt het belang van de toegenomen mogelijkheden voor onderwijsinstellingen om zich op het contract-onderwijs te richten. Dit heeft zowel directe (nabijer aanbod, goedkoop) als indirecte gevolgen (meer concurrentie op de opleidingsmarkt). Zie kader 4.4 .

\section{Training of allocatie}

Bij de vraag 'training of allocatie' gaat het om een tweetal keuzes:

- kunnen beter onervaren personen (lees: schoolverlaters) worden geworven of kan beter worden gekozen voor ervaren personen?;

- vormt training een substituut voor een eventueel hoger opleidingsniveau of is het complementair?

Kader 4.4

De invloed van institutionele ontwikkelingen

\section{CASE: PRESS, TECHNISCH BEDRIJF}

Bij PRESS wordt het overgrote gedeelte van de opleidingsvraag $(75 \%)$ uitbesteed. Bij de uitbesteding van opleidingen wordt gebruik gemaakt van het Grafisch Opleidings Centrum (GOC) te V., het Grafisch Lyceum te E., de leverancier van softwarepakketten en de leverancier van hardware. De laatste twee manieren wordt wel klantentraining genoemd. Dit is vaak de gemakkelijkste oplossing omdat het in een zeer specifieke opleidingsbehoefte voorziet, maar de kwaliteit van deze after-sales-service van leveranciers laat vaak te wensen over. Het grootste deel van de opleidingen wordt echter uitbesteed aan het Grafisch Opleidings Centrum. Dit is een coördinerend, branchegericht opleidingsinstituut. In het nabije verleden had het GOC een monopoliepositie, bood een goede kwaliteit aan opleidingen, maar was zeker niet goedkoop en leverde geen maatwerk. Gedwongen door de opkomst van de contractactiviteiten in het reguliere onderwijs begint het GOC zich te heroriënteren en te herpositioneren op de opleidingsmarkt. Zij ervaren de druk van nieuwe concurrenten.

Het Grafische Lyceum te E. is zo'n reguliere onderwijsinstelling, die zich tegenwoordig nadrukkelijker op de particuliere opleidingsmarkt manifesteert. De toch al sterke binding met dit nabij gelegen Lyceum wordt hierdoor nog eens versterkt. Het Grafisch Lyceum is in toenemende mate een reëel alternatief voor het Grafisch Opleidingscentrum.

Wat betreft de eerste keuze, kiest OFFITEC duidelijk voor schoolverlaters, en wel om twee redenen. Ten eerste heeft men slechte ervaringen met het werven van ervaren mensen die reeds bij andere bedrijven hebben gewerkt. Deze mensen hebben bewezen mobieler te zijn en dus is ook hun kans op verloop bij OFFITEC groter. Bij de afdeling Research \& Development zijn enkele jaren geleden bijvoorbeeld een aantal ervaren medewerkers aangenomen, waarvan na 3 jaar $50 \%$ weer verdween. Ten dele heeft dit overigens te maken met de geringere loopbaanmogelijkheden bij Research \& Development. Ten tweede zijn schoolverlaters 
nog flexibel en kunnen ze gemakkelijker in de eigen organisatie worden ingepast en wennen aan de bedrijfscultuur van OFFITEC. Omdat men dus slechte ervaringen heeft met het werven van ervaren mensen op de externe arbeidsmarkt, voelt men zich genoodzaakt schoolverlaters aan te nemen en deze zelf op te leiden.

Bij de andere bedrijven kiest men grosso modo meestal ook voor schoolverlaters. Het past toch wat meer bij de traditie van het bedrijf, het geeft mensen groeikansen en het voorkomt frustraties bij het zittende personeel.

Toch worden hier en daar wel uitzonderingen gemaakt. SWITCH zoekt bijvoorbeeld nog naar mensen voor het vervullen van senior commerciële functies, met veel kennis en ervaring. Bij SWITCH doet het werven van ervaren mensen in plaats van het opleiden van zittend personeel vermoeden, dat het gaat om een te groot verschil tussen de intern beschikbare kwalificaties en de vereiste kwalificaties, gecombineerd met de te lange duur van de eventuele training om het gat te dichten. Ook SOFTWARE zoekt naar oudere mensen (van 35 tot 45 jaar) met een gedegen branche- of bedrijfsspecifieke achtergrond. Bij dit bedrijf lijkt dit bovendien te duiden op een meer strategische keuze, waarbij iets minder schoolverlaters worden geworven en iets meer ervaren krachten worden ingehuurd. De reden hiervoor blijft enigszins onduidelijk. De omslag in het beleid bij SOFTWARE kan te maken hebben met het hoge vrijwillige verloop bij de jonge goed getrainde werknemers die intern zijn 'opgekweekt'.

De algemene indruk is dat de meeste bedrijven ${ }^{10}$, in de meeste situaties onervaren personen prefereren die men dan zelf opleidt, maar dat er om verschillende redenen soms wel uitzonderingen worden gemaakt. Die uitzonderingen zijn:

- het vrijwillig verloop bij het zittende, goed opgeleide personeel is te groot;

- de kwalificatiediscrepanties zijn te groot;

- training duurt tijd terwijl allocatie het probleem vrijwel meteen oplost;

- enigszins speculatief: het op alle niveaus openhouden van de organisatie houdt het zittende personeel alert.

Dan stappen we nu over op het tweede keuze-probleem: vormt training een substituut voor een eventueel hoger opleidingsniveau of is het complementair? We zullen MOSSO als voorbeeld nemen. Het grootste gedeelte van het personeelsbestand bij MOSSO bestaat uit produktiepersoneel. Hiervoor worden met name LTS-ers op B- of C-niveau en herintredende vrouwen aangenomen. Op zich is de arbeid zeer eenvoudig van aard en kan een handeling in één dag of maximaal één week worden aangeleerd. Toch wordt bij de selectie nogal wat aandacht besteed

10. Dit kan ook te maken hebben met de 'selection bias' in het onderzoeksdesign. Alleen bedrijven die aan opleidingen doen, zijn benaderd. 
aan het aspect 'verantwoordelijkheidsgevoel'. Fouten kunnen namelijk wel tienduizend gulden kosten. Werknemers moeten bovendien met de microscoop kunnen omgaan en het werk enigszins kunnen afstemmen. Bovendien is de 'trainability' van belang. Dit alles leidt ertoe dat geen LTS-ers met het A-niveau of ongeschoolden in dienst worden genomen. lets oudere werknemers (herintredende vrouwen) of schoolverlaters met een iets hoger initieel opleidingsniveau hebben de voorkeur want zij hebben meer verantwoordelijkheidsgevoel en zijn beter trainbaar. Kortom, training is in dit bedrijf geen substituut voor een hoger opleidingsniveau maar het is complementair. Er wordt dus niet gekozen voor een hoger opleidingsniveau omdat dan minder getraind hoeft te worden, maar er wordt gekozen voor een hoger opleidingsniveau omdat zij beter/goedkoper trainbaar zijn.

Kader 4.5

Training of allocatie?

\section{CASE: MOSSO}

Het opleidingsbeleid bij MOSSO te N. is gebaseerd op 7 uitgangspunten:

- met opleiden moet het bedrijfsbelang gediend worden;

- ook op langere termijn moet over het juiste personeel beschikt worden;

- er moeten mogelijkheden en faciliteiten aanwezig zijn, zodat het personeel zijn capaciteiten kan ontwikkelen;

- 'dóór en vóór N.', oftewel de kennis die hier aanwezig is moet ook gebruikt worden;

- het management moet bij het opleiden betrokken worden;

- de baten moeten in verhouding staan tot de kosten; en

- er moeten flexibele vormen van leren betracht worden, die gestalte krijgen in onder andere een open leercentrum.

Opleiden wordt gezien als een tool of management. Allereerst wordt een analyse van de organisatiepraktijk uitgevoerd via het vaststellen van een mogelijke discrepantie tussen de feitelijke en de gewenste bedrijfssituatie. Daarna vindt een strategie-keuze plaats, die betrekking heeft op personele ontwikkeling en/of organisatorische ontwikkeling. Op basis van deze analyses en keuzes, kan gekozen worden voor het middel 'opleiden'. Daarna vindt de formulering van de opleidingsdoelstellingen en de uitvoering van de opleidingsactiviteiten plaats. Tot slot wordt geëvalueerd op basis van drie criteria, te weten effect, effectiviteit en adequaatheid

Dat MOSSO over dit soort keuzes goed heeft nagedacht blijkt onder meer uit kader 4.5. Opleiden is slechts één manier om een probleem op te lossen. Op deze makeor-buy beslissingen komen we straks ook nog terug bij de keuze voor externe opleidingen versus interne opleidingen.

Training van binnenuit gezien

\section{Organisatiekenmerken}

Organisatie- en managementoverwegingen spelen bij bijna alle bedrijven een rol. Meestal is dit een reactie op ontwikkelingen in de markt of op technologische 
ontwikkelingen. Soms lijken deze overwegingen echter enigszins op zich zelf te staan. Om dit te benadrukken is het bedrijf 'COURANT' uitgekozen (zie kader 4.6). Binnen dit bedrijf lijkt duidelijk sprake te zijn van een cultuuromslag. De rol van met name het middenkader moet een andere worden.

Hierin is voor het opleidingsbeleid een taak weggelegd. Wellicht is het proces enigszins bespoedigd door nogal wat onzekerheden die op het bedrijf afkomen. Dit geldt zeker voor het 'pre press'-gebeuren en daarnaast brengt de fusiebespreking de nodige onzekerheid met zich mee, omdat de beoogde schaalvoordelen werkplekken zulien kosten. Heel tegenstrijdig is dat ondanks deze onzekerheden, men het bedrijf niet verlaat, deels door gebrek aan alternatieven en deels door de grote trouw aan het bedrijf.

Kader 4.6

Het belang van organisatievraagstukken

\section{CASE: COURANT}

De belangrijkste activiteit van de uitgeversmaatschappij 'COURANT' is het uitgeven van het regionale dagblad 'DE COURANT'. Na enkele overnames en fusies werd in 1988 'COURANT' onderdeel van het UITGEEF-concern.

De invoering van een andere organisatiecultuur, waarbij meer naar output en rendement wordt gekeken, wordt belemmerd door een gebrekkig middenkader en een zeer sterke functionele opdeling van de organisatie, waarbij horizontale communicatie nauwelijks mogelijk is en alles bovenlangs verloopt. Het personeelsbeleid is daarom sterk gericht op de verbetering van dit kader, ten aanzien van hun managementvaardigheden en hun interne communicatie, en op het inrichten van een efficiëntere organisatie.

Tot enkele jaren geleden werd er aan het opleidingsbeleid geen enkele sturing gegeven. Thans is afgesproken dat in elk geval $1 \%$ van de totale loonsom aan opleidingen kan worden besteed. Het opleidingsbeleid kan nu redelijk sturend worden genoemd. $\mathrm{Er}$ is nog wel de van hoog tot laag geldende aantrekkelijke tegemoetkoming in de studiekosten. Hierbij wordt de spontane behoefte afgewacht en wordt een verzoek om het volgen van scholing gehonoreerd waarvan maar enigszins gunstige effecten worden verwacht op de huidige of toekomstige functie binnen het UITGEEF-concern. De overige bestedingen van het beschikbare $1 \%$-budget worden wèl duidelijk gericht, met name de trainingsuitgaven voor het bijspijkeren van de managementvaardigheden bij het middenkader. Dit heeft als doel het doorbreken van het disciplinaire denken bij het middenkader.

\section{Training en produktiviteit}

Alle geïnterviewde personen geven aan dat training loont. Deze personen werken echter bij een bedrijf dat feitelijk traint en zij werken ook nog eens juist in de trainingsafdeling van het bedrijf. Uit onderstaande beweringen over training moeten dus geen algemeen geldende conclusies worden getrokken. Het zijn slechts 
(subjectieve) meningen van hoge opleidingsfunctionarissen of hoofden van de afdeling opleidingen, over de relatie tussen training en produktiviteit.

De baten van training zijn van zowel kwantitatieve als kwalitatieve aard. In kader 4.7 wordt de situatie bij PRESS beschreven, waarbij dit samenspel van zowel kwantitatieve als kwalitatieve baten goed waarneembaar is.

Bij SOFTWARE zou de concurrentiepositie verloren gaan als niet getraind werd. De volgende baten van opleidingen worden genoemd:

- uniformiteit in taalgebruik en vocabulaire;

- uitwisselbaarheid van mensen bij afwezigheid en verloop;

- betere inzetbaarheid van medewerkers;

- gestructureerde aanpak van probleemoplossing;

- inzetbaarheid in een hogere rang;

- snellere produktiviteit of minder inwerktijd.

Bij OFFITEC zijn twee produktie-onderdelen ISO-gekwalificeerd. Men kan echter niet vaststellen of dit aan de opleidingsinspanning is toe te schrijven. Verder heeft OFFITEC een goed voorbeeld van een duidelijke bate van een opleiding. Dit betreft de cursus over de elektromagnetische storingsgevoeligheid van elektronica. Deze cursus zorgt voor minder storing bij de kopieerapparaten en is dus zeer belangrijk voor de kwaliteit van de produkten. De cursus is zelfs zó belangrijk, dat het volgen van deze cursus voor hardware-engineers verplicht is.

Op de vraag wat er zou gebeuren als er niet getraind zou worden binnen het bedrijf, antwoordde de opleidingsstrateeg van TELEC: 'de systemen zullen niet meer kunnen functioneren en er zal chaos en een hoop trammelant ontstaan'. Dit typeert prima hoe er binnen de onderzochte bedrijven gedacht wordt over training. In zijn algemeenheid schat men op basis van de omgevingsontwikkelingen in, dat goed opgeleid en goed getraind personeel van (wezenlijk) belang is voor de organisatie, dat training niet zo gruwelijk veel geld kost (meestal enkele procenten van de loonsom), dat de effecten weliswaar niet aangetoond kunnen worden maar dat toch de (gerechtvaardigde) opvatting heerst dat zonder training veel zou misgaan.

Ten opzichte van enkele jaren geleden wordt een duidelijke koppeling gelegd tussen het bedrijfsbelang en training. Bij vrijwel alle onderzochte bedrijven wordt het belang van deze koppeling benadrukt, ondanks het feit dat deze koppeling nog niet geheel is voltooid en ondanks het feit dat er nog steeds getraind wordt uit oogpunt van rechtvaardigheidsoverwegingen of 'fringe benefit'. Men kan stellen dat ook bij training als 'fringe benefit' de uitgaven nog geen 'weggegooid geld' zijn, aangezien deze voor de werknemers altijd nog een immateriële beloning hebben opgeleverd, hetgeen misschien voorkomt dat additionele looneisen worden gesteld. Dus al heeft 
training slechts de functie van 'fringe benefit' dan gaat het nog niet per se tegen het belang van de organisatie in. Alleen als training algemeen bruikbaar is (voor de naaste en nabije concurrenten), het door werknemers niet wordt opgevat als 'fringe benefit' en training tevens gepaard gaat met een hoog vrijwillig verloop, is het zaak om de trainingsactiviteiten te heroverwegen. Maar zelfs in dát geval kan het alternatief (geen training) duurder zijn (SOFTWARE is hierbij het interessantste voorbeeld).

Kader 4.7

Training en produktiviteit

\section{CASE: PRESS, HET TECHNISCH BEDRIJF}

Het bedrijf PRESS bestaat uit de onderdelen: redactie, commercie en het technisch bedrijf. Het technische bedrijf bestaat uit een drietal afdelingen: zetterij, drukkerij en expeditie.

In 1992 bedroegen de opleidingskosten van het technisch bedrijf van PRESS $f$ 441.000,(1.8\% van de 24,8 miljoen gulden aan salarislasten). Hierin zijn de kosten van de afdeling opleiding ( $f 180.000,-)$, de doorbetaalde salarissen van de cursisten ( $f 250.000,-)$ en de out-ofpocket-kosten ( $f 11.000,-)$ begrepen. In dit bedrag zijn niet de specifieke projecten meegeteld. In het zogenaamde persenplan is bijvoorbeeld voor een periode van drie jaar ongeveer 1,6 miljoen gulden aan opleidingskosten besteed, waarvan 0,7 miljoen gulden betrekking heeft op de doorbetaling van de salarissen tijdens de stageperiodes. Dit specifieke project betrof 55 drukkers, die in vier groepen, ieder gedurende één jaar opgeleid en getraind werden. Zij liepen allen 3 maanden stage bij andere bedrijven en namen deel aan de cursus offset-rotatie drukker bij het grafisch opleidingsinstituut te Veenendaal. In totaal nam dit project drie jaar in beslag, zodat men in deze drie jaar per jaar nog telkens 0,5 miljoen gulden aan opleidingskosten kan toevoegen.

De inschatting van de baten van opleidingen is moeilijk omdat men nooit kan vergelijken, wat er was gebeurd als men niet opgeleid had en omdat er altijd meerdere factoren in het geding zijn. Desondanks worden enkele baten genoemd:

-beter gemotiveerd personeel

-bewuster met het werk bezig zijn;

-zelfverzekerde bediening van apparaten en machines;

-een betere kwaliteit, ofschoon hierbij ook de houding van het management van doorslaggevend belang is;

$-20-25 \%$ kortere inwerktijden

-voor wat betreft de drukkerii: een besparing op het papierverbruik. Een groot gedeelte van de $10 \%$ reductie op het papierverbruik ( 24 miljoen $\times 10 \%=2,4$ miljoen gulden) is toe te schrijven aan de opleidingsinspanning, waardoor de investering van 1,6 miljoen aan opleidingen in het persenplan alweer terugverdiend is.

\section{Beoordeling van de produktiviteit}

Bij MOSSO gelooft men niet in de kwantitatieve benadering. Men is echter van mening dat toch zinvol kan worden omgegaan met de schaarse middelen indien bij elke trainingsbeslissing de opleidingsdoelstellingen en de opleidingsactiviteiten geëvalueerd worden op basis van de volgende drie criteria: effect, effectiviteit en adequaatheid. Het criterium 'effect' wil zeggen: beheerst de persoon de stof die behandeld is? Het criterium 'effectiviteit' wil zeggen: kan de persoon het geleerde in 
de praktijk toepassen? Het criterium 'adequaatheid' betekent ten slotte: is dit de oplossing voor het probleem? Aan de hand van deze drie criteria kan het rendement van opleidingen op een kwalitatieve manier worden bepaald. De formulering van de doelstellingen en de evaluatie achteraf vinden in samenspraak met de chef en de afdeling opleidingen plaats. Overigens bleek bij meerdere bedrijven dat alleen al door het stellen van vragen aan het lijnmanagement, als 'Wat levert het op?' er een zinvolle discussie over de beoordeling en het nut van training op gang kwam.

Kader 4.8

Beoordeling van de produktiviteit

\section{CASE: BANCO}

Naar schatting wordt bij BANCO zo'n 120-160 miljoen gulden aan opleidingen uitgegeven. Dit omvat de personele lasten van de werknemers van de afdeling training \& development, de out- of-pocket-kosten, het lesmateriaal en de reis- en verblijfkosten van de cursisten. In dit bedrag zijn niet de kosten van gederfde arbeidsuren opgenomen ('lost opportunity costs'). Deze 120-160 miljoen gulden vormt zo'n 3,1\% van de 4.5 miljard aan salariskosten. Een besparing op deze opleidingskosten heeft niet de allereerste prioriteit, aangezien een besparing van $10 \%$ (14 miljoen gulden) slechts $0,3 \%$ aan salarislasten zou opleveren.

De resultaten van het onderzoek naar de effectiviteit van opleidingen, is allerminst positief. Slechts $20 \%$ van de werknemers die functiegerichte opleidingen gevolgd hebben, brengt de opgedane kennis in de praktijk (slechte transfer van kennis). Voor anderen komt de cursus te vroeg, te laat, of mogen ze de kennis niet in praktijk brengen. Kennelijk heeft een baas andere motieven voor het opleiden gehad, zoals 'het is nooit weg', of 'verkapt loon'. Er is nochtans geen grote actie op touw gezet om de lage effectiviteit te verbeteren. Dit heeft te maken met de moeilijke meetbaarheid van de baten en het rendement en gezien de relatief geringe uitgaven voor opleidingen (zie hierboven). Wel wordt getracht het kostenbewustzijn te vergroten en is er effectevaluatie ingevoerd. Effectevaluatie heeft als doel de bijdrage van de opleiding aan de beoogde verandering in de werksituatie in kaart te brengen, of met andere woorden antwoord te krijgen op de vraag: zijn de opleidingsdoelen gerealiseerd? De manager moet tegenwoordig van te voren aangeven wat de opleidingsdoelen precies zijn. Indien dit onvoldoende duidelijk is, wordt de aanvraag voor het volgen van een opleiding niet gehonoreerd (en dit gebeurt steeds vaker).

SOFTWARE lijkt een fraaie oplossing gevonden te hebben voor wat betreft de bepaling van de waarde van training. Training is hier waard wat de afnemer ervoor wil betalen. De divisie 'Professional Development', die de training verzorgt, heeft net als alle andere divisies een omzetverantwoordelijkheid (met uitzondering van de divisie 'Service Development'). In principe ligt de verantwoordelijkheid en het bijbehorende budget voor training bij het lijnmanagement. Zij kunnen in een trainingsbehoefte voorzien door een opleiding te kopen. Dit kan zowel intern als extern geschieden. De trainingsbehoefte wordt grotendeels vastgesteld door jaarlijkse review-gesprekken tussen de lijnmanagers en de medewerkers en de uitkomsten ervan, worden aan de divisie 'Professional Development' doorgegeven en omgezet in opleidingsplannen. Een probleem zou zich alleen kunnen voordoen als er trainingsbehoeften bestaan die het divisie-belang overstijgen. De centrale divi- 
sie 'Professional Development' ondervangt dit door nog additionele behoeften te formuleren. Het is niet bekend of deze additionele training gratis is of via een omslagstelsel in rekening wordt gebracht.

Bij BANCO is vastgesteld dat slechts $20 \%$ van de werknemers, die een functiegerichte opleiding hebben gevolgd de opgedane kennis in praktijk brengt. Toch heeft een besparing op de opleidingskosten niet de allereerste prioriteit. De opleidingskosten bedragen namelijk $3,1 \%$ van de loonsom en een besparing van bijvoorbeeld $10 \%$, hierop zou slechts $0,31 \%$ van de loonsom opleveren (zie kader 4.8 ). Als men zich realiseert dat BANCO in vergelijking met andere bedrijven nog relatief véél aan opleidingen uitgeeft dan kan men zich voorstellen hoe klein de eventuele besparing bij andere bedrijven is.

\section{Beoordeling van training}

Er zijn drie mogelijkheden voor het vaststellen van de opleidingsbehoeften. Allereerst kan de opleidingsafdeling de behoefte aan opleidingen vaststellen en deze min of meer dwingend opleggen aan de werknemer en aan de afdeling of lijnmanager. Daarnaast kan de verantwoordelijkheid geheel in handen worden gelegd van het lijnmanagement of de afdeling. En tot slot kan het individu verantwoordelijk worden gesteld voor het vaststellen van de eigen opleidingsbehoeften. $\mathrm{Er}$ is een duidelijk spanningsveld tussen de drie benaderingen en de onderzochte bedrijven komen meestal uit op een combinatie hiervan.

In het verleden waren er bij TELEC 13 districten met elk hun eigen afdeling opleidingen, die de opleidingsbehoefte vaststelden. De verantwoordelijkheid lag bij de opleidingsafdelingen: zij kondigden nieuwe zaken aan e.d. Tegenwoordig tracht men tot een opsplitsing tussen aanbod- en vraagzijde te komen. De opleidingsafdelingen vormen de aanbodzijde die op een marktconforme manier produkten en diensten moeten aanleveren. De vraagzijde wordt in feite door alle managers gevormd. Als de vraag naar opleidingen op een gestructureerde wijze wordt ingebracht dan kan op tijd gebruik gemaakt worden van het interne of externe opleidingsaanbod. De Business Units en het lokale management maken de opleidingsjaarplannen, zorgen voor het budget, denken na over bestaande of toekomstige kwalificatietekorten etc. Deze bevoegdheid is zoveel mogelijk een lijnverantwoordelijkheid. Dit plannen is moeilijk voor managers en vaak zijn de plannen dan ook niet betrouwbaar. De centrale opleidingsafdeling van TELEC ondersteunt in die gevallen het management en tracht structuur aan te brengen in het inventariseren van de vraagzijde.

Het laatste geeft duidelijk aan dat er een spanningsveld is tussen het op decentraal niveau laten vaststellen van de opleidingsbehoefte en het laten inventariseren van 
de opleidingsbehoefte door een centrale afdeling. Wat gebeurt er namelijk als op decentraal niveau geen of de verkeerde opleidingsbehoefte wordt vastgesteld? Wat te doen als er een overstijgend centraal belang is en er bijvoorbeeld door het lijnmanagement een perspectief op een te korte termijn wordt gehanteerd? Het lokale management verwacht soms activiteiten van de opleidingsafdeling, want het heeft zelf veel andere dingen aan het hoofd. $\mathrm{Er}$ is dan altijd de neiging om ook de opleidingsbehoeften vanuit een centrale opleidingsafdeling te dirigeren. Ondanks de vaak geuite wens om de opleidingsbehoeften op decentraal niveau vast te stellen, zien we in de cases dan ook duidelijk de directe of indirecte invloed van de centrale opleidingsafdeling in het vaststellen van de opleidingsbehoeften. Dit gebeurt vaak zeer impliciet door gewoontevorming (o.a. PRESS), maar ook wel door min of meer gestandaardiseerde opleidingspaden (o.a. SOFTWARE) of door richtlijnen ten aanzien van de te besteden opleidingskosten per werknemer (o.a. TELEC). Bij de onderzochte bedrijven wordt dan graag gesproken over 'faciliteren', oftewel zodanige condities scheppen opdat het lijnmanagement de opleidingsbehoeften beter kan vaststellen.

Bij SOFTWARE volgt bijvoorbeeld het merendeel van de werknemers een opleiding en volgt een bepaald opleidingspad. De volgende opleidingspaden worden onderscheiden: 'programmering', 'systeemanalyse', 'systeemontwerp', 'informatie-analyse', 'projecten', en 'consultancy'. In elk opleidingspad zijn telkens ongeveer 10 vaste cursussen of workshops opgenomen en sommige opleidingspaden (met name programmering en informatie-analyse) bevatten daarnaast nog een fiks aantal facultatieve cursussen of workshops. Aan elke werknemer wordt per jaar gemiddeld tussen de $f 5.500$ en $f 8.000$ aan opleidingen besteed. Een divisie, een divisieafdeling of een lijnmanager kan echter besluiten naar beneden of naar boven af te wijken of het geld buiten het bedrijf te besteden. De verantwoordelijkheid hiervoor ligt dus niet bij de opleidingsdivisie Professional Development. Toch is de invloed van de afdeling Professional Development door het bestaan van dergelijke opleidingspaden heel goed merkbaar.

Bij TELEC geeft de directie een aanwijzing aan het lokale management om gemiddeld iedereen 6 dagen per jaar te laten leren. Ze geeft echter maar een normbedrag van $f 3.000$ per medewerker wat een equivalent van ongeveer 4 dagen cursussen betekent. De overige 2 dagen zouden op een andere wijze moeten worden ingericht. In de praktijk ziet men, dat het lokale management zich vaak houdt aan deze $f$ 3.000. De opleidingsafdeling zegt dan dat dit een té strikte interpretatie is, omdat er juist voor gezorgd moet worden dat het geld afhankelijk van de reële, bedrijfs- en situatiegebonden behoefte wordt besteed. Feitelijk wordt door een dergelijke aanwijzing een gedeelte van de opleidingsbehoefte toch door centrale krachten bepaald. 
In de inleidende alinea werd gesteld dat de verantwoordelijkheid voor het vaststellen van de opleidingsbehoefte ook bij de werknemer zèlf kan liggen. Dit sluit dan aan bij het idee dat werknemers mondig en zelfbewust zijn en heel goed zèlf kunnen bepalen waar men behoefte aan heeft. Bij SWITCH lijkt dit idee het verst doorgevoerd te zijn. Daar is een uitgangspunt bij het opleidingsbeleid geformuleerd, dat stelt dat het initiatief bij opleidings- en loopbaankwesties in eerste instantie bij de werknemer ligt. Werknemers dienen hier dus zèlf de verantwoordelijkheid te nemen voor de ontwikkeling van hun talenten. SWITCH volstaat met het stimuleren van werknemers en het bieden van mogelijkheden. Er zijn geen uitgestippelde loopbaanpaden, maar wel gangbare routes. Maar ook hier is er sprake van een constante wisselwerking tussen de opleidingsafdeling, het lijnmanagement en de individuele werknemer in het feitelijk vaststellen van de opleidingsbehoefte.

Ten opzichte van het verleden is er toch wel een verschuiving te zien. De algehele verantwoordelijkheid lag voorheen uitsluitend bij de centrale opleidingsafdeling, terwijl men tegenwoordig groeit naar een gedeelde verantwoordelijkheid tussen de centrale afdeling, het lijnmanagement en soms de werknemer. Ook in deze trend zien we terug dat de opleidingsfunctie een wat minder geïsoleerde functie gaat vormen en dichter bij de feitelijke produktieprocessen en de feitelijke opleidingsbehoeften wordt geplaatst. Dit leidt ook tot een andere rol van de opleidingsafdeling. Om dit te laten zien nemen we de case BANCO. Hier stelt men dat de 'klassieke' opleidingsfunctionarissen, die uitsluitend kennis of vaardigheden overdragen, zullen verdwijnen. Er zal ook steeds meer met externe opleidingsinstituten worden gewerkt. Dit betekent dat opleidingsfunctionarissen andere taken zullen krijgen. De volgende vier taken zullen dominanter worden:

- het beoordelen van de kwaliteit van de externe opleidingsinstituten

- het in kaart brengen van de opleidingsbehoefte binnen het bedrijf;

- het koppelen van een opleidingsadvies met een organisatie-advies;

- het ontwikkelen van nieuwe ideeën, leermethoden etc.

Kortom, een verschuiving van het primaire opleiden, naar het inventariseren, controleren, onderzoeken, ontwikkelen en evalueren van opleidingen.

\section{Training en beloning}

In geen enkele case werd expliciet aangegeven dat gekozen werd voor een zo specifiek mogelijke training, ten einde de extra beloning beperkt te kunnen houden. In ook geen enkele case werd algemene training door de werknemer en specifieke training door de werkgever betaalt. In beide gevallen bleek namelijk de werkgever te 
betalen ${ }^{11}$. Stimulering van on-the-job training heeft wel prioriteit boven off-the-job training. De ondernemingen zouden lerende organisaties moeten worden en geen opleidende organisaties. In sommige bedrijven is on-the-job training zeer dominant (bijvoorbeeld OFFITEC en PRESS). Toch werd door geen enkel bedrijf aangegeven dat on-the-job training verkozen wordt boven off-the-job training omdat het gunstige effecten voor de loonsom zou hebben. Meestal gaat on-the-job training overigens hand in hand met off-the-job-training omdat dit ook pedagogische voordelen heeft. Wel geven de meeste bedrijven de voorkeur aan specifieke technische opleidingen boven management-opleidingen, omdat dan de baten beter meetbaar zijn en wellicht ook omdat de hierbij verkregen kwalificaties minder bruikbaar zijn in andere bedrijven. De geografische nabijheid van concurrenten waar dezelfde kwalificaties wenselijk zijn, speelt hierbij ook een rol.

Kader 4.9

Training als immateriële beloning

\section{CASE: TELEC}

Enkele jaren geleden waren opleidingen een soort verkapt loon ('vandaag Pietersen, morgen Janssen'). Men begint daar langzaam aan heel anders over te denken en men begint in te zien dat het bijdraagt aan de kwaliteit van de organisatie en de kwaliteit van de output. Managers beginnen nu ook te beseffen dat opleiden iets kost. De vraagstelling 'wat zijn de baten?' is dan ook volkomen nieuw.

De omslag naar een bedrijfsgericht opleidingsbeleid kan niet van vandaag op morgen gerealiseerd worden. Zo zijn er nog steeds zogenaamde persoonlijk gekozen opleidingen die voortkomen uit de specifieke belangstelling van werknemers, zonder dat er sprake is van een reële opleidingsnoodzaak voor de werkgever. Bij wijze van 'fringe benefit' betaalt de werkgever vaak meer dan $50 \%$ van de kosten bij persoonlijk gekozen opleidingen.

Voor werknemers heeft training twee functies. Enerzijds is het een middel om een hoger loon te verwerven, met name bij off-the-job training, en anderzijds kan het een vorm van directe, immateriële beloning vormen. Welke functie het ook vervult, in de meeste onderzochte bedrijven is er geen tekortschietende belangstelling van werknemers om getraind te worden, ofschoon er bij BANCO geen sprake lijkt te zijn van een overdosis van carrière-gerichte personen. Wat betreft de tweede functie van training voor individuen, dat wil zeggen de immateriële beloning, kan gezegd worden dat bij de meeste bedrijven ook nog wel persoonsgerichte training voorkomt, die niet of nauwelijks in verband staat met de directe produktiviteit (zie kader 4.9). Soms is er een studiekostenregeling, waarbij het begrip 'nuttig voor het bedrijf' ruim wordt geïnterpreteerd (bijvoorbeeld bij COURANT).

11. Het zou zo kunnen zijn dat een werknemer meebetaalt aan algemene training door inlevering van loon (bijvoorbeeld minder loonstijging). Dit werd echter nimmer door de geinterviewden naar voren gebracht. 


\section{Training en mobiliteit}

In deze paragraaf besteden we eerst aandacht aan de relatie tussen training en interne mobiliteit en daarna wordt de relatie tussen training en externe mobiliteit besproken. Enkele voorbeelden worden eruit gelicht.

Bij MOSSO wordt - met betrekking tot de interne mobiliteit - voor het midden- en hogere kader een discrepantie gesignaleerd tussen de wenselijke en de feitelijke situatie. Het beleid is gericht op een doorstroming tussen de verschillende vestigingen van MOSSO, ten einde te komen tot een hogere 'employability' en een verruiming van het blikveld. In feite is de horizontale interne mobiliteit van het midden- en hogere kader echter vrij gering en blijft momenteel voornamelijk beperkt tot de doorstroming naar $Y$. of tot de doorstroming naar de MOSSO Semiconductors-vestiging in Frankrijk. Met maatregelen, zoals de afkondiging van een maximale verblijfsduur in functies, probeert de concernleiding enige dwang uit te oefenen. Dit is soms nodig om het spanningsveld tussen het decentrale belang (talent lokaal behouden) en het centrale belang (goede doorstroming) in het voordeel van het laatste te beslechten. Bij het produktiepersoneel is de interne mobiliteit nog veel lager dan bij het hogere personeel, maar dit wordt niet als problematisch ervaren.

Bij SWITCH ervaart men eveneens de nodige moeilijkheden om de horizontale interne mobiliteit te vergroten. SWITCH biedt in principe ontwikkelingsmogelijkheden voor alle groepen personeel: 'employee development' voor CAO-A-ers, 'career development' voor jonge academici en HBO-ers, 'management development' voor hogere managers en een 'leadership continuity programme' voor executives. Aangezien SWITCH echter wordt gekenmerkt door een relatief platte organisatiestructuur en door een jonge gemiddelde leeftijd van het personeel (34-35 jaar), kan niet aan iedereen de mogelijkheid tot opwaartse verticale mobiliteit worden geboden. Soms is SWITCH gedwongen om (slechts) horizontale mobiliteit aan te bieden. Dit is voor sommige werknemers moeilijk te accepteren.

Training en interne mobiliteit gaan vaak hand in hand. Regelmatig wordt er dan ook van het totaalbegrip 'personeelsontwikkeling' gesproken. Voor zover de interne mobiliteit verticaal is gericht, zal dit door de werknemer als aantrekkelijk worden ervaren, omdat dit meestal leidt tot loonsverhoging. Organisaties worden echter platter en ook de leeftijdsstructuur kan zodanig zijn, dat er minder verticale mobiliteit kan plaatsvinden. Daarnaast kan soms een beperkte groei van de organisatie belemmerend werken voor een individu dat hogerop wil. Dit leidt dan tot min of meer gedwongen horizontale mobiliteit. In tegenstelling tot bij de verticale mobiliteit, zijn er bij horizontale mobiliteit niet per se parallelle belangen tussen werkgever en werknemer. 
Kader 4.10

Training en mobiliteit

\section{CASE: SOFTWARE}

Het vrijwillige verloop bij SOFTWARE is vrij hoog. Binnen alle software-huizen geldt in feite het principe van 'up-or-out'. Aangezien er niet altijd mogelijkheden zijn om verticaal binnen het eigen bedrijf door te stromen, verandert men regelmatig van werkgever. Soms wordt een aanbieding gedaan door de klant waarbij men op dat moment werkt. Soms gaat men naar een concurrerend softwarebedrijf of kiest men weer het oude beroep. In de informatica-wereld zitten namelijk veel omgeschoolde academici (bijvoorbeeld wiskunde-leraren), die een rustiger omgeving in hun oude beroep opzoeken.

Een personeelsissue dat op dit moment erg speelt is het opzetten en implementeren van horizontale en duale carrièreladders. In het verleden kwamen vrijwel uitsluitend verticale en op management gerichte carrièreladders voor. Zo'n standaard carrière-pad zag er bij goede prestaties als volgt uit: eerst programmeur dan functioneel ontwerper dan projectleider en dan verkoper. In het personeelsbeleid bouwt men nu langzamerhand de mogelijkheid van horizontale doorstroming en vakspecialistische carrières in. Of dit de cultuur van 'up-or-out' kan doorbreken is nog maar de vraag. Door het volwassen worden van de branche c.q. het bedrijf zijn er op een gegeven moment gewoonweg onvoldoende mogelijkheden om iedereen in verticale richting te laten doorgroeien.

Aan elke werknemer wordt per jaar gemiddeld tussen de $f 5.500$ en $f 8.000$ aan opleidingen besteed. Dit bedrag is exclusief de tegemoetkoming in de studiekosten en de 'lost opportunity costs'. Het vrijwillig verloop bij SOFTWARE is tamelijk hoog. Voorheen moesten de werknemers van het bedrijf WARE in de eerste drie jaar van hun dienstverband een gedeelte van de opleidingskosten bij vertrek terugbetalen. Bij SOFT bestond deze terugbetalingsregeling niet. Bij SOFTWARE bestaat er ook geen officiële terugbetalingsregeling, ofschoon er op lokaal niveau best individuele juridische afspraken gemaakt zouden kunnen worden.

Bij MOSSO heeft als gevolg van de twee reorganisaties veel gedwongen externe mobiliteit plaatsgevonden. Daarentegen is de vrijwillige externe mobiliteit erg laag. Dit verbaast enigszins omdat men verwachtte dat de goede werknemers naar aanleiding van de reorganisaties zouden opstappen. Dat dit nauwelijks gebeurde heeft te maken met een aantal oorzaken. Allereerst blijken, met name de produktiewerknemers, nogal regionaal gebonden te zijn, terwijl in regio $\mathrm{N}$. de arbeidsmarkt voor deze categorie werknemers niet erg rooskleurig is. Daarnaast verrichten de hoger geschoolden (HBO'ers, academici en promovendi) vaak zo'n specifieke arbeid, dat men vrijwel nergens anders naar toe kan.

Het risico van externe mobiliteit is afhankelijk van tal van factoren zoals de situatie op de arbeidsmarkt, de kosten van mobiliteit (bijvoorbeeld verhuiskosten), de regionale binding en ook de mate waarin men specifiek gekwalificeerd is. Bij MOSSO is de arbeid vaak zo specifiek, dat de kwalificaties voor andere bedrijven geen enkele waarde hebben. Bij SOFTWARE ligt dit heel anders (zie kader 4.10). Daar zijn de kwalificaties nogal algemeen van aard en wordt zelfs gestreefd naar 'uniformiteit in taalgebruik en vocabulaire', 'uitwisselbaarheid van mensen' en 'brede inzetbaarheid'. Dit heeft binnen het bedrijf kennelijk gunstige produktiviteitseffecten, 
maar het draagt tevens het gevaar in zich dat de opgedane kwalificaties gemakkelijk overdraagbaar zijn aan andere organisaties. Daarbij speelt dat de werknemers van SOFTWARE vrijwel voortdurend bij de klanten aanwezig zijn, waardoor de verleiding groot is om bij deze klant in dienst te treden. Vreemd genoeg wordt voor dit probleem geen oplossing bedacht. SOFTWARE betaalt ook deze training volledig en in juridische binding, in de vorm van bijvoorbeeld een terugbetalingsregeling, ziet men nauwelijks heil. Wellicht is men gedwongen een ander wervingsbeleid, zoals het wegkopen van ervaren mensen, te kiezen of moeten de kosten van externe mobiliteit worden verhoogd door het verschaffen van spaarregelingen, hypotheekleningen e.d.

Er is een juridische mogelijheid tot terugbetaling van (een gedeelte van) de opleidingskosten geregeld bij zowel TELEC ('bij dure loopbaangerichte opleidingen'), MOSSO ('bij managementopleidingen'), OFFITEC ('kan geëist worden'), PRESS ('in incidentele gevallen'), BANCO ('onder bepaalde condities') als SOFTWARE ('eventueel op decentraal niveau'). De geïnterviewden bij deze bedrijven gaan geen van allen prat op deze terugbetalingsregelingen, maar kennelijk zijn ze in sommige gevallen wel noodzakelijk. Functiegerichte opleidingen komen wat minder snel voor terugbetaling in aanmerking dan loopbaangerichte of managementopleidingen. Indien deze onderverdeling tussen functiegerichte en loopbaangerichte opleidingen parallel loopt met de theoretische onderverdeling in 'algemene training' versus 'specifieke training' (zie hoofdstuk drie) dan zien we een aardige bevestiging van de theorie. In de buitenlandse cases kwamen terugbetalingsregelingen nimmer voor. Kennelijk zijn ook institutionele factoren van belang (waarden, normen, gewoontes, wetgeving).

\section{Trainingsmethoden en soorten training}

Tot slot van dit hoofdstuk over training in de praktijk worden de onderzoeksresultaten met betrekking tot de vorm en de inhoud van training uit de doeken gedaan. Kader 4.11 toont voor BANCO de verschillen tussen elektronische leermethoden en docentafhankelijke leermethoden (binnen eenzelfde bedrijf) met elk zijn voor- en nadelen.

Verder is het concept 'leren' in plaats van het concept 'opleiden' nogal populair bij de onderzochte bedrijven. Er wordt getracht leercondities aan te brengen die verder gaan dan het verzorgen van cursussen. Het grootste gedeelte van wat men 'leert', vindt plaats gedurende de uitvoering van de normale werkzaamheden. Bij OFFITEC wordt het aandeel on-the-job training op $90 \%$ geschat. Ook bij PRESS geeft men aan dat het grafische vak toch vooral in de praktijk wordt geleerd, dus niet op school noch bij opleidingsinstituten. Als on-the-job-training effectiever is dan het volgen van een cursus dan moet gewoonweg op de werkplek worden geleerd, zegt 
men bij TELEC. Zij stimuleren dit door bijvoorbeeld de aanstelling van zogenaamde 'procesapplicatiecoaches'. Deze coaches lopen rond op de werkplek, ondersteunen de werknemers indien nodig, zorgen dat mensen bij elkaar komen als er problemen zijn, kortom verlichten het management op het gebied van instrueren en inleren. Bij SWITCH erkent men dat men nog teveel een opleidende organisatie is en het is dan ook de bedoeling dat SWITCH in de toekomst een lerende organisatie moet worden. Dit betekent een andere rol voor de opleiders. De opleiders van nu zijn onderwijskundigen, maar zij zullen in toenemende mate andere taken en oriëntaties moeten krijgen. Zij zullen zich bijvoorbeeld meer met on-the-job-training en met de organisatorische ontwikkeling van een afdeling of het bedrijf moeten bezighouden.

Kader 4.11

Verschillende trainingsmethoden

\section{CASE: BANCO}

BANCO-UNO had in de 80-er jaren het docentafhankelijke onderwijs afgezworen en koos voor de elektronische, software-matige manieren van leren. Dit bracht grote kostenvoordelen met zich mee en het was bovendien individualistisch van karakter. Op deze manier kon gemakkelijk omgegaan worden met individuele verschillen in capaciteit, in tempo, in tijdsvoorkeur etc. Het nadeel van deze elektronische leermethode was echter het gebrek aan interactie met de medemens. Bij BANCO-DOS was het docentafhankelijke onderwijs wel actueel en bestond er een traditie om ervaren managers uit het bankbedrijf voor een paar jaar naar de afdeling opleidingen te halen. Deze mensen hadden vaak veel kennis van het bankwezen, maar het ontbrak aan didactische vaardigheden.

Bovengenoemde ingrediënten en ervaringen zijn gebruikt voor het huidige opleidingsbeleid bij het gefuseerde BANCO. Allereerst is een verschuiving in de manier van opleiden te signaleren. Opleiden wordt niet meer gezien als het volgen van een cursus, maar als het 'creëren van leercondities'. Dit wordt bijvoorbeeld uitgewerkt in het leren op de werkplek en het 'walkin-concept'. Bij BANCO zijn individualistische leermethodes niet ongebruikelijk. Dagelijks kunnen bijvoorbeeld 1500 deelnemers via het eigen computernetwerk in een afgescheiden opleidingsomgeving een cursus volgen. Zij kunnen zelfstandig inloggen, nemen hun eigen opleidingssetje, regelen zèlf het tempo, etc. Deze vorm van leren wordt gecombineerd met verschillende mondelinge en schriftelijke vormen van opleiden.

Verder blijkt dat veelal onderscheid gemaakt wordt tussen:

- functiegerichte opleidingen;

- loopbaangerichte opleidingen;

- themagerichte opleidingen;

- organisatiegerichte opleidingen;

- persoonsgerichte opleidingen.

Functiegerichte opleidingen komen in alle onderzochte bedrijven voor en gelden meestal voor alle categorieën werknemers. Loopbaangerichte opleidingen zijn vaak voorbehouden aan de hoger opgeleide werknemers in de grotere bedrijven. Een opleidingspad gaat dan soms hand in hand met een loopbaanpad (bijvoorbeeld SOFTWARE). Themagerichte opleidingen hebben een tijdelijk karakter. Een 
voorbeeld hiervan is het bedrijf COURANT dat de communicatie in het bedrijf wil verbeteren (met name bij het middenkader). De komst van een nieuwe pers bij het bedrijf PRESS had ook themagerichte opleidingen ten gevolge. Onder organisatiegerichte opleidingen valt bijvoorbeeld een introductiecursus bij indiensttreding. Tot slot de persoonsgerichte cursussen die vaak deels een 'fringe benefit'-karakter hebben. Deze opleidingen worden soms (gedeeltelijk) door het bedrijf vergoed, ook al staat het belang voor de organisatie nog niet vast.

Bovengenoemde soorten opleidingen worden soms intern en soms extern verzorgd. In dit onderzoek gaat het niet om de kwantiteiten maar om de argumenten om al dan niet een opleiding zèlf te verzorgen. De algemene indruk bestaat dat de onderzochte bedrijven het liefst zo weinig mogelijk zèlf opleiden, aangezien dit niet tot de 'core business' behoort. Soms is men echter genoodzaakt om toch zelf op te leiden. MOSSO noemt de volgende criteria die daarbij een rol kunnen spelen:

- strategie: Is de kennis van groot strategisch belang voor de organisatie?

- kwaliteit: Is de kwaliteit van externe opleidingen slechter dan de eigen trainingorganisatie en het eigen aanbod van cursussen?;

- kosten: Zijn de uitbestedingskosten hoger dan de interne kosten?;

- inhoud: Kan de inhoud van de cursus een negatieve invloed hebben op het imago van het bedrijf?

- cultuur: Is kennis van de bedrijfscultuur belangrijk?

- onafhankelijkheid: Is onafhankelijkheid in uitvoering van groot belang?

Als het antwoord op bovengenoemde vragen bevestigend is, is MOSSO geneigd de opleidingen zelf te ontwikkelen en uit te voeren. In het selecteren van een extern opleidingsinstituut speelt de reputatie van het instituut, eerdere ervaringen, de lokatie, de kwaliteit en de prijs van de cursussen een belangrijke rol. Soms wordt een extern opleidingsinstituut beschouwd als een zogenaamd 'preferent centrum'. Andere gehoorde argumenten zijn:

Pro extern:

- het interne opleidingsinstituut blijft onder druk staan (TELEC);

- externe opleidingen zijn meestal goedkoper zeker als ze in de avonduren plaatsvinden (OFFITEC);

Pro intern:

- sommige, vooral specialistische, cursussen of opleidingen zijn niet verkrijgbaar bij externe instituten (TELEC en SWITCH);

De onderzochte bedrijven hebben weliswaar het voornemen om meer uit te besteden, in de praktijk blijkt dat toch vaak intern wordt opgeleid. Een gemakkelijke vorm van uitbesteding is overigens de steeds populairder wordende 'klantentraining'. Bij de installatie van nieuwe machines, gereedschappen of programmatuur worden de betrokkenen door het toeleverende bedrijf geschoold. Men is overigens niet altijd 
even tevreden over de kwaliteit van deze klantentraining.

\subsection{Samenvatting en conclusie}

Dit hoofstuk doet verslag van het empirisch gedeelte van het onderzoek 'Costs and Benefits of Training'. De doelstelling betrof het in kaart brengen van de kosten en baten van bedrijfsopleidingen (inclusief externe opleidingen) in een context van de nationale onderwijssystemen en de specifieke arbeidsmarktsituatie. Daartoe zijn in zes landen tezamen 48 casestudies verricht.

Marktontwikkelingen kunnen leiden tot de behoefte aan een flexibeler werknemersbestand en tot een grotere mate van kwaliteitscontrole. In het bankwezen was er bij het middenkader een grotere behoefte aan verkooptraining en bij het hogere kader een grotere behoefte aan onderhandelingsvaardigheden. In het Nederlandse telecommunicatiebedrijf bleken de liberalisering en internationalisering grote, nieuwe behoeften aan leerprocessen teweeg te brengen. In een Nederlands softwarehuis bleek op grond van marktontwikkelingen, dat er een toenemende behoefte ontstaat aan werknemers met veel meer branche- en bedrijfsgerichte expertise.

Niet alleen marktontwikkelingen maar ook technologische ontwikkelingen zijn zeer belangrijk voor de vereiste kwalificaties van werknemers. Wel is dit sterk afhankelijk van het type organisatie en kan niet gesproken worden van een uni-causale relatie. Technologische ontwikkelingen zijn sterk gekoppeld aan functiegerichte training. In een Nederlands elektrotechnisch bedrijf bleek dat bij de recente korting op de trainingsbudgetten eerst de niet-functiegerichte training onder het mes ging. In een Nederlandse drukkerij hadden de technologische ontwikkelingen ten gevolge dat de subafdelingen in de zetterij kwamen te vervallen en dat daardoor ook bredere vaardigheden in die afdeling werden vereist. Bovendien bleek uit deze case dat technologische ontwikkelingen schoksgewijs verlopen.

In de casestudies kwam het belang van de arbeidsmarkt voor het opleidingsbeleid nauwelijks naar voren. Voor alle zes bij het onderzoek betrokken landen geldt dat men tevreden is over hun onderwijssysteem en over de mogelijkheid om zowel goed gekwalificeerde schoolverlaters, als ook ervaren mensen aan te trekken. Dit zal ongetwijfeld te maken hebben met de in alle landen aanwezige aanbodoverschotten op de externe arbeidsmarkt anno 1993. Toch worden ook wel specifieke tekorten genoemd die niet door training zijn weg te werken. In Nederland wordt bijvoorbeeld genoemd: de universitaire studie hoog-frequentie technologie en ICtechnologie, MTS-elektrotechniek, TU-ers of HTS-ers met enige commerciële kennis en senior commerciële functies.

In de meeste van de zes deelnemende EU-landen wordt naar een aanpassing van 
het onderwijssysteem gezocht, die een nauwere aansluiting tussen het onderwijs en de arbeidsmarkt waarborgt. In Nederland is ook een dergelijke institutionele ontwikkeling waar te nemen. Verder werd in Nederland gesproken van een zeer ondoorzichtige bedrijfs- en externe opleidingsmarkt. De toegenomen mogelijkheden van reguliere onderwijsinstellingen om contractonderwijs aan te bieden wordt verwelkomd, al was het alleen maar al omdat het de bestaande aanbieders op de opleidingsmarkt onder druk zet.

Bedrijven maken een keuze tussen allocatie en training. De algemene indruk is dat de meeste onderzochte bedrijven, in de meeste situaties onervaren personen prefereren die men dan zelf opleidt, maar dat er om verschillende redenen soms wel uitzonderingen worden gemaakt. Die uitzonderingen zijn:

- hoog vrijwillig verloop bij het zittende, goed opgeleide personeel;

- de kwalificatiediscrepanties zijn te groot;

- training duurt tijd terwijl allocatie het probleem meteen oplost;

- de noodzaak om het zittende personeel alert te houden.

In vrijwel elk bedrijf wordt het opleidingsbeleid nauwer gekoppeld aan het algemene bedrijfsbeleid. Dit heeft deels te maken met de ten tijde van het onderzoek bestaande bezuinigingsrondes, hetgeen de trainingsbudgetten onder druk zette. Maar er is toch meer aan de hand, want de positie van het opleidingsbeleid als onderdeel van het totale beleid is vergroot en het creëren van een goed opgeleid personeelsbestand is daarbij soms een middel om uit het dal te geraken. Training is tegenwoordig minder snel een 'fringe benefit' en vormt vaker een onderdeel van het algehele 'human resource'- beleid. In zijn algemeenheid schat men op basis van de omgevingsontwikkelingen in, dat goed opgeleid en goed getraind personeel van (wezenlijk) belang is voor de organisatie, dat training niet zo gruwelijk veel geld kost (meestal enkele procenten van de loonsom), dat de effecten weliswaar niet aangetoond kunnen worden maar dat toch de (gerechtvaardigde) opvatting heerst dat zonder training veel mis zou gaan.

De baten van training zijn niet (volledig) meetbaar. Dit wordt niet altijd als problematisch ervaren want er kan ook anderszins efficiënter met de middelen worden omgegaan. Dit anderszins efficiënter omgaan met de middelen kan bijvoorbeeld door het louter stellen van de vragen als: wat is het effect?, wat is de effectiviteit? en, is training een adequate oplossing voor het probleem? Het is ook belangrijk om te letten op de timing van een cursus. De onmeetbaarheid van de baten kan als weinig problematisch worden gezien, omdat de benodigde beoordelingskosten niet zullen opwegen tegen de eventuele besparing op de trainingsuitgaven. Men is bovendien eerder geneigd om te bezuinigen op managementopleidingen (waarvan de opbrengsten onzeker zijn) of terugbetalingsregelingen af te spreken (bij wijze van preventieve maatregel) bij onvrijwillig vertrek van goed getrainde personen. 
Dit wil overigens niet zeggen dat training niet loont. Er is door gesprekspersonen uit de onderzochte bedrijven onomwonden gezegd dat training een (forse) bijdrage levert aan het bedrijfsbelang en dat de kosten van 'not training' zeer hoog zouden zijn en tot een ernstige aantasting van de concurrentiepositie zullen leiden.

Bij de beoordeling van de opleidingsbehoeften is een verschuiving te zien ten opzichte van het verleden. De algehele verantwoordelijkheid lag voorheen uitsluitend bij de centrale opleidingsafdeling, terwijl men tegenwoordig toegaat naar een gedeelde verantwoordelijkheid tussen de centrale afdeling, het lijnmanagement en soms de werknemer. Ook in deze trend zien we terug dat de opleidingsfunctie een wat minder geïsoleerde functie gaat vormen en dichter bij de feitelijke produktieprocessen en de feitelijke opleidingsbehoeften wordt geplaatst. Dit leidt ook tot een andere rol van de opleidingsafdeling. $\mathrm{Er}$ is in de opleidingsafdeling een verschuiving te zien van het primaire opleiden, naar het inventariseren, controleren, onderzoeken, ontwikkelen en evalueren van opleidingen. Het opleiden zèlf wordt het liefst zoveel mogelijk uitbesteed aan externe opleidingsinstituten, ofschoon er soms belangen zijn om dit niet te doen.

In de onderzochte bedrijven is on-the-job training dominanter aanwezig dan off-thejob training. Het is zelfs zo dat vele onderzochte organisaties een ontwikkeling willen doormaken van een 'opleidende' organisatie naar een 'lerende' organisatie. Dit betekent dat er meer on-the-job geleerd moet worden en dat er ook meer horizontale interne mobiliteit zou moeten plaatsvinden. Dit wordt overigens niet gefundeerd door te verwijzen naar een eventueel lagere loonsom, maar vanuit pedagogische en directe kosten/baten -overwegingen van training. De soms geuite behoefte aan meer multi-skilled werknemers wordt eerder bewerkstelligd door een gewenste toename van de interne mobiliteit en een toename van diverse vormen van on-the-job training, dan door het laten volgen van meer algemene, functieoverstijgende cursussen. Er waren geen geluiden te horen dat werknemers de koerswijziging in de richting van meer on-the-job training minder appreciëren, maar er is wel enige oppositie van werknemers tegen horizontale mobiliteit.

De externe mobiliteitskansen van werknemers zijn belangrijk en afhankelijk van vele factoren. De cases MOSSO en SOFTWARE vormen hierbij zeer interessante extremen. Het elektrotechnische bedrijf MOSSO hoeft niet zo bang te zijn voor de externe mobiliteit van de hoger opgeleiden, omdat deze soms zeer specifiek geschoold zijn (hoogfrequentie-technologie of IC-technologie). Bij de lager opgeleiden is de vrees niet aanwezig omdat zij nogal regionaal gebonden zijn. Bij het softwarehuis SOFTWARE daarentegen is er sprake van training in kwalificaties die zeer goed bruikbaar zijn in andere bedrijven en is bovendien de binding met het bedrijf zeer gering, omdat de werknemers het grootste gedeelte van de tijd bij klanten werken. Het vrijwillige verloop bij SOFTWARE is dan ook tamelijk groot, 
ondanks de forse salarissen. Dit hoeft echter niet per se te betekenen dat het softwarehuis onverstandig handelt, want de kosten van een eventuele 'not training' zijn in dit bedrijf erg hoog. 


\section{Conclusie en samenvatting}

In Nederland is er sprake van een tamelijk geringe trainingsintensiteit bij bedrijven, als we dit vergelijken met enkele andere landen. Waarschijnlijk heeft dit deels te maken met het Nederlandse initiële onderwijssysteem dat zowel naar niveau als naar richting sterk gedifferentieerd is. Wel is het zo dat in Nederland tussen 1986 en 1990 de opleidingskosten als percentage van de directe arbeidskosten zijn gestegen, hetgeen vooral is toe te schrijven aan de forse stijging van het gemiddelde aantal opleidingen per werknemer.

De trainingsintensiteit van bedrijven hangt sterk samen met de omvang en het soort organisatie. De opleidingskosten als percentage van de directe arbeidskosten zijn in bedrijven met minimaal 500 werknemers bijvoorbeeld 5 à 6 keer zo hoog als in bedrijven met ten hoogste 100 werknemers. De verschillen naar bedrijfsgrootte zijn tussen 1986 en 1990 wel enigszins afgenomen. De grotere trainingsintensiteit bij grotere bedrijven heeft gedeeltelijk te maken met het gemiddeld hogere opleidingsniveau van het personeel in deze bedrijven, maar bijvoorbeeld ook met economiesof-scale voordelen. Verder is de trainingsintensiteit, zoals opgemerkt, sterk afhankelijk van het soort organisatie. Uit zowel internationaal als nationaal onderzoek blijkt dat er sprake is van een grote spreiding van de trainingsindicatoren over de verschillende bedrijfsklassen. Sommige bedrijfstakken scoren in alle landen hoog (bijvoorbeeld de financiële sector) en sommige bedrijfstakken scoren in alle landen laag (bijvoorbeeld de textielsector). De trainingsintensiteit in een land wordt dus sterk beïnvloed door de structuur van de werkgelegenheid in een land.

Uit een analyse van arbeidsmarktgegevens van Nederlandse schoolverlaters bleek dat ook voor deze specifieke groep op de arbeidsmarkt geldt dat grotere organisaties een hoger gemiddeld opleidingsniveau werven en bovendien meer trainen. De diverse bedrijfsklassen waarin schoolverlaters werkzaam zijn werden ingedeeld in vier kwadranten: bedrijfsklassen die weinig trainen en een laag opleidingsniveau werven ('SQUEEZE'), bedrijfsklassen die veel trainen en een hoog opleidingsniveau werven ('ACCUMULATE'), bedrijfsklassen die weinig trainen maar een hoog opleidingsniveau werven ('BUY') en bedrijfsklassen die een laag opleidingsniveau werven maar wel veel trainen ('MAKE'). Bovendien werd het volgende gevonden:

- voor met name de verklaring van de verschillen in opleidingsniveau maakt het veel uit of het leerlingwezen en in-service onderwijs bij de definitie van training wordt meegeteld. Met name de VBO/MAVO-ers scoren dan veel hoger, uiteraard omdat zij de gebruikelijke instroom vormen voor het leerlingwezen als vorm van voortgezet initieel onderwijs. Als het leerlingwezen en in-service onderwijs niet wordt meegeteld dan gaat de stelling op dat de kans op training toeneemt naarmate het opleidingsniveau stijgt; 
- er wel wordt gesteld dat het leerlingwezen en in-service onderwijs een goede onderwijsvorm is om training toegankelijker te maken voor kleine organisaties, waardoor de trainingsverschillen met grote organisaties zouden afnemen. Deze stelling gaat niet op voor middelgrote organisaties (tussen de 50 en 99 werknemers), want de trainingsverschillen tussen middelgrote en (zeer) grote organisaties bleek groter te zijn als ook rekening wordt gehouden met de training via het leerlingwezen/in-service onderwijs;

- er zijn niet alleen grote verschillen tussen bedrijfstakken in de mate van training, maar ook in het relatieve gebruik dat wordt gemaakt van het leerlingwezen en in-service onderwijs (relatief veel bij: reparatiebedrijven, bouwinstallatiebedrijven, handel in onroerende goederen).

Op grond van de theorievorming over scholing werd geconstateerd dat kwaliteit en flexibiliteit steeds dominantere performance-criteria voor bedrijven worden, hetgeen leidt tot een behoefte aan hoger en meer algemeen aanwendbaar menselijk kapitaal, dat bovendien flexibel inzetbaar is. Afzetmarktontwikkelingen blijken inderdaad soms te leiden tot de behoefte aan een flexibeler werknemersbestand. De indruk bestaat dat bedrijven eerder geneigd zijn om te kiezen voor een hoger opleidingsniveau van de instroom dan voor een trainingsprogramma dat gericht is op het creëren van meer algemeen aanwendbare kwalificaties onder het zittende personeel. Bovendien is een toename van de interne mobiliteit soms een geschikte mogelijkheid om de flexibiliteit te vergroten. Daarnaast werd in het ontwikkelde theoretisch kader (hoofdstuk 3) vastgesteld dat marktontwikkelingen, zoals een toenemende concurrentie zullen leiden tot een efficiënter beheer van het aanwezige menselijk kapitaal. Het veronderstelde efficiëntere beheer van het menselijk kapitaal is inderdaad een trend die duidelijk waarneembaar was in de onderzochte cases. In vrijwel elk bedrijf wordt het opleidingsbeleid nauwer gekoppeld aan het algemene bedrijfsbeleid. Training is tegenwoordig minder snel een 'fringe benefit' en vormt vaker een onderdeel van het algehele 'human resource'- beleid. In zijn algemeenheid schat men op basis van de omgevingsontwikkelingen in, dat een goed opgeleid en een goed getraind personeel van (wezenlijk) belang is voor de organisatie, dat training niet zo gruwelijk veel geld kost (meestal enkele procenten van de loonsom), dat de effecten weliswaar niet aangetoond kunnen worden, maar dat toch de (gerechtvaardigde) opvatting heerst dat zonder training veel zou misgaan.

Op grond van de theorie werd verwacht dat technologische ontwikkelingen leiden tot een hogere afschrijving van menselijk kapitaal, tot een verhoging van het niveau en de algemene aanwendbaarheid van het menselijk kapitaal, tot een veranderende branche- en beroepenstructuur en tot een upgrading van werkzaamheden. Technologische ontwikkelingen blijken inderdaad zeer belangrijk te zijn voor de vereiste kwalificaties van werknemers en ook vaak de voornaamste reden te zijn 
om te trainen. Wel is dit sterk afhankelijk van het type organisatie en kan niet gesproken worden van een uni-causale relatie. Technologische ontwikkelingen zijn sterk gekoppeld aan functiegerichte training. Uit de cases kwam evenwel niet (nadrukkelijk) naar voren dat technologische ontwikkelingen leiden tot een behoefte aan meer algemene kwalificaties.

In de theorievorming werd een duidelijke relatie gelegd tussen arbeidsmarktontwikkelingen (hoge uitbreidingsvraag bij hooggeschoold werk, meer onderbenutting, meer vergrijzing, grotere participatie van vrouwen) en trainingsvraagstukken, maar dit verband komt in de dagelijkse praktijk nauwelijks tot uitdrukking. Door de aanwezige aanbodoverschotten en door een redelijk gunstige ontwikkeling van het onderwijsbestel zien bedrijven de arbeidsmarktontwikkelingen veelal niet als een bedreiging. Training wordt overigens in zijn algemeenheid niet gezien als een geëigend middel om leemtes in de kwalificatiestructuur weg te werken. Kennelijk zou het trainingsrendement hierdoor onder een kritiek niveau (de marktrente) dalen. Een meer voor de hand liggende reactie op verschuivingen op de arbeidsmarkt is een aanpassing van het wervingsbeleid.

Bij de institutionele ontwikkelingen in Nederland werd genoemd: de nauwere aansluiting tussen het onderwijs en de arbeidsmarkt, de toenemende concurrentie op de opleidingsmarkt, de ondoorzichtige opleidingsmarkt en de 'laisser fair'houding van de overheid inzake training. De toegenomen mogelijkheden van reguliere onderwijsinstellingen om contractonderwijs aan te bieden wordt door bedrijven verwelkomd, al was het alleen maar omdat het de bestaande aanbieders op de opleidingsmarkt onder druk zet. Verder brengen de geïnterviewden naar voren dat er in Nederland kan worden gesproken van een nogal ondoorzichtige bedrijfs- en externe opleidingsmarkt.

Bij het ontwikkelde theoretische kader werd een afstemmingsmodel gepresenteerd, waarin omgevingsinvloeden leiden tot veranderingen van zowel de kwalificaties die voor de beroepsuitoefening zijn vereist als de kwalificaties waarvoor de beroepsbevolking beschikt. De afstemming van vereiste en beschikbare kwalificaties zouden dan leiden tot oftewel training (make/repair) oftewel allocatie (buy/sell). Afhankelijk van de omstandigheden wordt soms voor allocatie en soms voor training gekozen, zo is uit de cases is gebleken. Deze omstandigheden zijn bijvoorbeeld de omvang van kwalificatiediscrepanties, het personeelsverloop, de bedrijfscultuur etc.

Een inventarisatie van de stand van theorievorming voor training leidde in hoofdstuk 3 tot een human-resourcemodel met vijf belangrijke human-resourcedomeinen, namelijk mobiliteit, training, beloning, beoordeling en produktiviteit. Dit humanresource model bleek nuttig te zijn om de dagelijkse activiteiten in het personeelswerk in te delen en de relaties verder te analyseren. Dit wil echter niet zeggen dat 
de veronderstelde relaties tussen de verschillende human-resource domeinen (eenvoudig) bevestigd werden in de interviews. Zo werd bijvoorbeeld nimmer gesteld dat de kosten van algemene training in mindering worden gebracht op de beloning of dat bedrijfsspecifieke training leidt tot minder externe mobiliteit. In de gesprekken werd echter wel duidelijk dat bedrijven een voorkeur hebben voor onthe-job training en learning-by-doing, dat er vaak het eerst op algemene training wordt bezuinigd en dat werknemers soms moeten meebetalen in de 'out-of-pocket'kosten van algemene training.

Het nemen van beslissingen over de training van werknemers, is net als alle andere investeringsbeslissingen, in theorie het maken van een rekensom waarin kosten en baten tegen elkaar worden afgewogen. Aangezien echter voor een individueel bedrijf de methoden en technieken ontbreken om vast te stellen hoe de exacte relaties liggen en wat de precieze effecten zijn, is in de praktijk een globaal inzicht in de relaties soms al voldoende. Er wordt dan bijvoorbeeld geaccepteerd dat de baten van training niet (volledig) meetbaar zijn, dat de mobiliteitskansen moeilijk in te schatten zijn en dat het beloningsregime in een bedrijf vrij star is. De reële mogelijkheden die de onderzochte bedrijven ter beschikking staan is het verkleinen van de risico's door te proberen de potentiële terugverdientijd te beïnvloeden (het aannemen van schoolverlaters, voorzichtig zijn met reeds mobiel gebleken werknemers, preventieve terugbetalingsregelingen etc.), het vergroten van de potentiële produktiviteitsstijging die verbonden is aan training (betere transfer, timing, grotere effectiviteit, lerende organisatie, etc.) en tot slot het voorkomen dat de opbrengsten van training volledig naar de werknemers vloeien (liefst on-the-job training, niet overdraagbare of voor derden onzichtbare training). 


\section{Literatuur}

Aalders, M.J.A.M., Bedrijfsopleidingen organisatie en financieringsstructuur, Naar een verklaring van sectorale verschillen in omvang en structuur van bedrijfsopleidingen, Van Gorcum, Assen, 1994.

Ahaus, C.T.B. \& Kastelein, A., Ontwikkelingen in de contingency-benadering: enkele kritische kanttekeningen (1); Bedrijfskunde, jrg. 57, 1985/4.

Akerlof, G.A., \& J.L. Yellen, Efficiency wage models of the labor market, University of California, Berkeley, Cambridge University Press, 1987.

Aldrich, Howard \& Pfeffer, Environments of organizations. In: Alex Inkeles (ed.) An annual review of sociology, 1976.

Allaart, P.C., R. Kunnen en H.A. van Stiphout, Trendrapport vraag naar arbeid, Stichting Organisatie voor Strategisch Arbeidsmarktonderzoek, OSA-rapport nr. 11, november 1990.

Allaart, P.C., Labour market trends, research and politics. In: J.J. Siegers and F. Tazelaar (eds.), The Dutch labour market in 2000, Groningen, 1991.

Allaart, P.C. R. Kunnen, W.C.M. Praat, H.A. van Stiphout \& J.P. Vosse, Trendrapport aanbod van arbeid, Stichting Organisatie voor Strategisch Arbeidsmarktonderzoek (OSA), 1991.

Amelsvoort, P. van \& J. Buyse, Sociotechniek. In: POST-groep, Onderweg naar nieuwe fabrieken en kantoren, Kluwer Bedrijfswetenschappen, Deventer, 1991.

Auer, P., Further Training for the Employed: A discription of Country Models and an Analysis of European Labour Force Survey Data, Report to the Task Force Human Resources/Commsision of the European Communities, 1992.

Becker, G.S., Human capital, National Bureau of Economic Research, Phoenix Edition, 1980.

Broer, D.P., W.J. Jansen, Employment, Schooling and Productivity Growth, De Economist, 137, nr. 4, blz. 425-453, 1989.

Bronneman-Helmers, H.M., Volwasseneducatie tussen markt en overheid, Op zoek naar kerntaken van de overheid ten aanzien van onderwijs, vorming en scholing van volwassenen, Sociaal en Cultureel Planbureau, Rijswijk, 1992.

CBS, Bedrijfsopleidingen in Nederland, Centraal Bureau voor de Statistiek, Staatsuitgeverij, Den Haag, 1986.

CBS, Volwassenen-educatie en bedrifsopleidingen in Nederland, de particuliere sector, Centraal Bureau voor de Statistiek, Staatsuitgeverij, Den Haag, 1992.

Child, J. Organizational structure, environment and performance: the role strategic choice, In: Sociology 6, blz. 1-22, 1972.

Cörvers, F., Human Capital Factors at the Firm Level, Researchcentrum voor Onderwijs en Arbeidsmarkt, Rijksuniversiteit Limburg, ROA-W-1994/7E, Maastricht, 1994.

Diederen, P.J.M., R.P.M. Kemp, J. Muysken, F.C. Palm, C.P.A. Bartels en A.H. Webbink, Diffusie van technologie: gevolgen voor werkgelegenheid en beroepenstructuur, Rijksuniversiteit Limburg, Maastricht, 1988.

Doeringer, P.B, \& M.J. Piore, Internal Labor Markets and Manpower Analysis, M.E. Sharpe, Inc., 1985.

Dosi, G. Technological paradigms and technological trajectories, In: C. Freeman (ed), Long waves in the world economy, Buttersworth, Londen, 1983.

Douma, S.W., Op weg naar een economische organisatietheorie: de transactiekosten benadering, In: Maandblad voor Accountancy en Bedrijfshuishoudkunde; nr. 1/2, blz. 2-11, 1988.

Douma, S.W., Op weg naar een economische organisatietheorie: agency-theorie, In: Maandblad voor Accountancy en Bedrijfshuishoudkunde; nr. 11, blz. 420-432, 1987.

Flynn, Groenboek, Europees Sociaal Beleid, Opties voor de Unie, Commissie van de 
Europese Gemeenschappen, Directoraat-Generaal Werkgelegenheid, Industriele betrekkingen en Sociale Zaken, COM(93) 551, 17 november 1993.

Freeman, J. en Hannan, M.T. The population ecology of organizations. American Journal of Sociology, 8, blz. 929-964, 1977.

Grip, A. de, Winnaars en verliezers op de arbeidsmarkt 1981-1985, Verschuivingen in de beroepen- en opleidingsstructuur, Tijdschrift voor Arbeidsvraagstukken, jrg. 3, 1987a.

Grip, A. de, J.A.M. Heijke en E.J.T.A. Willems, The Costs of Not Training. Contribution for the Netherlands, ROA-W-1992/7E, Researchcentrum voor Onderwijs en Arbeidsmarkt, Maastricht, 1992.

Grip, A. de, Onderwijs en Arbeidsmarkt: scholingsdiscrepanties, VU Uitgeverij, Amsterdam, 1987b.

Grip, A. de, L.F.M. Groot, J.A.M. Heijke en E.J.T.A. Willems, De aans/uiting tussen beroepen en functies en de relatie met scholings- en mobiliteitsprocessen, ROA, OSA-werkdocument W 80, november 1990.

Groot, L.F.M., J.J. Schippers en J.J. Siegers, The effect of interruptions and part-time work on women's wage-rate: a test of the variable-intensity model, De Economist, Vol. 136, No. 2, 1988.

Grumbkow, J. von, Beloningen in organisaties, Nieuwe impulsen om prestaties te waarderen, Kluwer, Deventer, 1982.

Ham, J.C. van, Paauwe, J. en Williams, A.R.T. Human resources management en transactiekostenbenadering, in : Economisch Statistische Berichten, 23 november, blz. 1109-1112, 1988.

Hartog, J. \& Theeuwes, J.J.M., Arbeidseconomie, In: Geest, L. van der (red.), Economische theorie: de stand van zaken, Academic Service, 1990.

Hashimoto, M., Firm-Specific Human Capital as a Shared Investment, The American Economic Review, Volume 71, No. 3, June 1991.

Have, K. ten, Markt, organisatie en personeel in de industrie, Tilburg University Press, Tilburg, 1993.

Hay-groep, Human Resource Management, Beloning en kengetallen, Deventer, 1991.

Hendrikse, G.W.J. \& Schreuder, H., Economische organisatietheorie, in: L. van der Geest (red.) Economische theorie: de stand van zaken, Academic Service, Schoonhoven, 1990.

Hoevenberg, J., A. de Grip, Monitoring Skill Potentials for Technological Innovation and Diffusion, ROA-R-1994/14E, Researchcentrum voor Onderwijs en Arbeidsmarkt, Maastricht, november 1994.

Hoof, J.J. van \& J. Dronkers, Onderwijs en arbeidsmarkt: een verklaring van de relaties tussen onderwijs, arbeidsmarkt en arbeidssysteem, Van Loghum Slaterus, Deventer, 1980.

Hoof, J.J. van \& R.J. Huiskamp, New forms of workorganisation: The Dutch experience, Lake Balaton, Hungary, 1984.

Hoogedoorn, J., J.M. Walls \& C.J. Reincke, Veranderende eisen aan het personeelsmanagement, Rotterdam, 1989.

Houtkoop, W. \& Ch. Felix, Volwasseneneducatie in Europa, Een vergelijkende studie naar de volwasseneducatie in een aantal EG-landen en Zweden, RVE Adviescentrum Volwasseneneducatie, Utrecht, juli 1990.

Hövels, B., V. Esch \& J. van den Berg, Technologie, Substitutie en kwalificatie, Een onderzoek naar de betekenis van technologische ontwikkelingen voor de verhouding tussen HTS-inginieurs werktuigbouwkunde en elektrotechniek, OSA-voorstudie V28, Den Haag, 1988.

Huibregtsen, F.W. \& W.F.J. Lierop, Terug naar de menselijke maat, Economisch Statistische Berichten, 12 juni, 1991. 
Huijgen, F., De kwalitatieve structuur van de werkgelegenheid in Nederland, deel III. Bevolking in loondienst en functiestructuur in 1977 en 1985, 1989, Den Haag, OSA.

Katz, E. \& Ziderman, A., Investment in general training: the role of information and labour mobility, The Economic Journal, 100, 1147-1158, 1990.

Koopman, P.L. \& Pool, J., Vier modellen van strategische besluitvorming. In: Gedrag en organisatie, deel 3, juni, 1990.

Kuhry, B. \& Opstal, R. van, De arbeidsmarkt naar opleidingscategorie 1975-2000. In: Economisch Statistische Berichten, 20-1-1988.

Kuipers, H. Zelforganisatie als ontwerpprincipe. In: Gedrag en organisatie, 2, 4/5, 1989.

Kuipers, H., \& Amelsvoort, P.J. van, Slagvaardig organiseren: een inleiding in de sociotechniek als integrale ontwerpleer. Deventer, Kluwer, 1990.

Kumpe, T., P.T. Bolwijn, \& Goudswaard, Over ondernemen en industrieel elan, Kluwer, Deventer, 1985.

Lindley, R.M. \& T. Hogarth, Feasibility Study on the Costs of Not Training, Report to the Task Force on Human Resources, Commission of European Communities, 1992.

Lindley, R.M. \& T. Hogarth, Costs and Benefits of Training in Europe, Draft Final Report, Report to the Task Force on Human Resources, Commission of the European Communities, October 1993

Loo, P.J.E. van de , R.K.W. van der Velden, De arbeidsmarktpositie van afgestudeerden van het hoger onderwijs, HBO-monitor 1993, Researchcentrum voor Onderwijs en Arbeidsmarkt, Uitgave: Voorlichtingsdienst HBO-raad, september 1994.

Mintzberg, H., Structure in fives: Designing effective organizations, Prentice Hall, Engle Wood Cliff, New Yersey, 1983.

Morgan, G. Images of organization. Sage publications, 1986.

Muysken, J. et al, Diffusie van technologie en de ontwikkeling van de werkgelegenheid, Ministerie van Sociale Zaken en Werkgelegenheid, Den Haag, 1990.

OECD, Employment Outlook 1991, Parijs, juni 1991.

OECD, Employment Outlook 1993, Parijs, juli 1993.

Ouchi, W.G., 1979, A conceptual framework for the design of organizational control mechanisms, A conceptual framework for the design of orgnizational control mechanisms, in: Management Science, 9, p. 833-848.

Pot, F. Het einde van de arbeidsdeling?, Tijdschrift voor Arbeidsvraagstukken, jrg. 1, nr. 2, 1985.

Ritzen, J.M.M., Market failure for General Training, and Remedies, in: D. Stern and J.M.M Ritzen (eds.), Market failure in Training? New Economic Analysis and Evidence on Training of Adult Employees, Springer-Verlag, Berlin, 1991.

ROA, De arbeidsmarkt naar opleiding en beroep tot 1998, Researchcentrum voor Onderwijs en Arbeidsmarkt, ROA-R-1993/10, Maastricht, 1993.

Schwan, R., Organisationskonfigurationen und Interne Arbeitsmärkte, Eine theoretischempirische Untersuchung vor Arbetsorganisationen im Zeichen interner Arbeitsmärkte Wirtschaftswissenschafliche Fakultät der Rijksuniversiteit Limburg, Maastricht, Nederland 1993.

Simon, H.A. Models of man, New York: Wiley, 1957.

Simon, H.A. Human nature in politics: the dialoque of psychology with political science, American Political Science Review, 79, 1985.

Sitter, L. de, Het flexibele bedrijf, Groep Sociotechniek, Kluwer Bedrijfswetenschappen, 1987. Smoorenburg, M.S.M. van, R.K.W. van der Velden, P.J.E. van de Loo \& M. H. Wieling, Schoolverlaters op de arbeidsmarkt, de uistroom en bestemming van het schooljaar 1991- 
1992, Researchcentrum voor Onderwijs en Arbeidsmarkt, uitgave: Stichting Landelijk Dienstverlenend Centrum voor Studie- en Beroepskeuzevoorlichting, Leeuwarden, april 1994.

Spence, A.M., Market signaling: Informational transfer in hiring and related training processes, Cambridge MA, Harvard, 1974.

Teulings, C.N. \& H.M. Budil-Nadvornikova, De betekenis van bedrijfsopleidingen in Nederland, Stichting voor Economisch Onderzoek, rapport nr. 235, 1989.

TFHR, Synoptic Tables, Information available in the twelve member states on continuing vocational training, Task Force on Human Resources, FORCE, Commision of the European Communities, 1992.

TFHR, Managing chart on continuing vocational education, Comparative study Belgium, Denmark, Germany, Spain, France, Greece, Ireland, Italy, Luxembourg, The Netherlands, Portugal, Great-Britain, Task Force on Human Resources, Force Technical Assistance Office, March 1993

Tichy, N.M., C.J. Fombrun, M.A. Devanna, Strategic human resource management, Sloan Management Review, 1982.

Wasser, B., De afdeling opleidingen bij Philips in Nederland, Nederlands Genootschap van Leraren, 20e jaargang, 7 januari, 1988.

Williamson, O.E., The economics of organization: the transaction cost approach, In: American Journal of Sociology, Vol. 87, no.3, 1981.

Wolfs, G., Internal Labour markets: Towards an integrated model, Ecozoek, 11 mei, 1988.

Womack, J.P., D.T. Jones \& D. Roos, The machine that changed the world, The story of lean production, Harper Perrenial, 1991. 


\section{Bijlage I}

Labels bedrijfsklassen conform de standaard bedrijfsindeling (CBS)

01 Land- en tuinbouw

02 Bosbouw

03 Visserij

11 Kolenmijnbouw

12 Aardolie- en aardgaswinning en -exploratie

19 Overige delfstoffenwinning

20 Voedings- en genotmiddelenindustrie

22 Textielindustrie

23 Kledingindustrie

24 Leder-, schoen- e.a. lederwarenindustrie (excl. kleding)

25 Hout- en meubelindustrie (excl. metalen meubelen)

26 Papier- en papierwarenindustrie

27 Grafische industrie, uitgeverijen en binderijen

28 Aardolie- en steenkoolverwerkende industrie

29 Chemische industrie

30 Kunstmatige en synthet. garen- en vezelindustrie

31 Rubber- en kunststofverwerkende industrie

32 Bouwmaterialen-, aardewerk-, en glasindustrie

33 Basismetaalindustrie

34 Metaalprod.industrie (excl.machines en transportmidd.)

35 Machine-industrie

36 Elektrotechnische industrie

37 Transportmiddelenindustrie

38 Instrumenten- en optische industrie

39 Overige industrie

40 Prod. en distr. van elektr., gas, water;warmtevoorz.bedr.

50 Bouwnijverheid en installatiebedrijven

51 Bouwnijverheid

52 Bouwinstallatiebedrijven ed

60 Handel,hotel en rest.,reparatie bedr gebr.goederen

61 Groot- en tussenhandel

65 Detailhandel

67 Hotels, restaurants, cafe's ed

68 Reparatiebedrijven voor gebruiksgoederen

70 Transport-,opslag- en communicatie bedr.

71 Spoorwegen

72 Wegvervoer

73 Zeevaart 
74 Binnenvaart

75 Luchtvaart

76 Hulpbedrijven van het vervoer

77 Communicatiebedrijven

80 Bank en verzekeringswezen, zakelijke dienstverlening

81 Bankwezen

82 Verzekeringswezen

83 Exploitatie van en handel in onroerende goederen ed

84 Zakelijke dienstverlening

85 Verhuur van machines e.a. roerende goederen

86 Top- en hulporganen

87 Veilingen

90 Openb. bestuur, defensie, wettel. sociale verz.

91 Religieuze ea levensbeschouwelijke organisaties

92 Onderwijs

93 Gezondheids- en veterinaire diensten

94 Maatschappelijke dienstverlening

95 Sociaal-culturele en culturele instellingen

96 Sport en recreatie

97 Bedrijfs- en werkn.org.,researchinstell.,ea soc. org.

98 Overige dienstverlenende bedrijven

99 Organisaties zonder aktiviteit

100 Overig 


\section{Bijlage II}

\section{Schatting kans op training}

$\mathrm{Er}$ is gebruik gemaakt van het gekoppelde, ongewogen bestand van de HBOmonitor 1993 (uitstroom uit het schooljaar 1991-1992) en RUBS 1993 (uitstroom uit het schooljaar 1991-1992). Het moment van enqueteren is voor de HBO-ers november/december 1993 en voor de AVO-ers, VBO-ers, KMBO-ers en MBO-ers mei/juni/juli 1993.

Een logistische regressievergelijking is geschat voor diegenen die op het moment van enquêteren tot de werkzame personen behoorden. Dit betreft 19.728 geselecteerde cases, waarvan 3.112 cases uit de analyse zijn weggevallen wegens missende waarden.

De refentiegroep is:

Mannelijke autochtonen, die in het schooljaar 1991-1992 een technische opleiding hebben gevolgd op VBO/MAVO-niveau en die op het moment van enquête in een organisatie werken met tussen de 50 en 99 werknemers in de elektrotechnische industrie (sbi 36).

De te verklaren variabelen zijn als volgt geoperationaliseerd:

training incl. Ilw

$1=$ op het moment van enquêteren wordt een cursus (geen hobbycursus of een voltijds vervolgopleiding) of een opleiding in het kader van het leerlingwezen/inservice onderwijs gevolgd;

$0=$ op het moment van enquêteren wordt noch een cursus (geen hobbycursus of een voltijdsvervolgopleiding) noch een opleiding in het kader van het leerlingwezen/inservice onderwijs gevolgd.

training excl. Ilw

$1=$ op het moment van enquêteren wordt een cursus (geen hobbycursus, geen voltijds vervolgopleiding en ook geen opleiding in het kader van het leerlingwezen/in-service onderwijs) gevolgd;

$0=$ op het moment van enquêteren wordt geen cursus (geen hobbycursus, geen voltijds vervolgopleiding en ook geen opleding in het kader van het leerlingwezen/in-service onderwijs) gevolgd.

De verklarende variabelen zijn als volgt geoperationaliseerd:

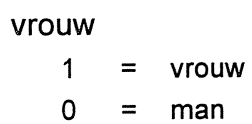

$1=$ allochtoon 


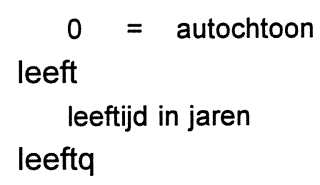

gekwadrateerde leeftijd in jaren

1-9 wn.

$1=$ werkt in een organisatie met 1-9 werknemers

$0=$ werkt in een organisatie met geen 1-9 werknemers

10-49 wn.

1 = werkt in een organisatie met 10-49 werknemers

$0=$ werkt in een organisatie met geen 10-49 werknemers

50-99 wn.

$1=$ werkt in een organisatie met 50-99 werknemers

$0=$ werkt in een organisatie met geen 50-99 werknemers

opm: $50-99$ wn.' is de refentiecategorie

100-499 wn.

1 = werkt in een organisatie met 100-499 werknemers

$0=$ werkt in een organisatie met geen 100-499 werknemers

500-999 wn.

$1=$ werkt in een organisatie met 500-999 werknemers

$0=$ werkt in een organisatie met geen 500-999 werknemers

$\geq 1000$ wn.

$1=$ werkt in een organisatie met 1000 of meer werknemers

$0=$ werkt in een organisatie met geen 1000 of meer werknemers

sbi1 (idem sbi20..sbi100)

$1=$ werkt in sbi-bedrijfsklasse 1 ; zie bijlage 1

$0=$ werkt niet in sbi-bedrijfsklasse 1

opm: sbi36 (elektrotechnische industrie) is de referentiecategorie

opl. niveau 0

$1=$ de hoogst voltooide opleiding is de basisschool

$0=$ de hoogst voltooide opleiding is geen basisschool

opl. niveau 1

1 = de hoogst voltooide opleiding is een VBO of MAVO-opleiding

$0=$ de hoogst voltooide opleiding is geen basischool of MAVO-opleiding

opl. niveau 2

$1=$ de hoogst voltooide opleiding is het KMBO

$0=$ de hoogst voltooide opleiding is geen $\mathrm{KMBO}$

opl. niveau 3

1 = de hoogst voltooide opleiding is het MBO, het HAVO of het WWO

$0=$ de hoogst voltooide opleiding is geen MBO, HAVO of WWO

opm: opl. niveau 3 is de referentiecategorie

opl. niveau 4

$1=$ de hoogst voltooide opleiding is het $\mathrm{HBO}$

$0=$ de hoogst voltooide opleiding is geen $\mathrm{HBO}$ 
agrar. opl.

1 = de laatst gevolgde opleiding is een agrarische beroepsopleiding

0 = de laatst gevolgde opleiding is geen agrarische beroepsopleiding techn. opl.

1 = de laatst gevolgde opleiding is een technische beroepsopleiding

0 = de laatst gevolgde opleiding is geen technische beroepsopleiding opm: 'techn. opl.' is de refentiecategorie econ.adm.. opl.

1 = de laatst gevolgde opleiding is een economische administratieve beroepsopleiding

0 = de laatst gevolgde opleiding is geen economisch administratieve beroepsopleiding verzorg. opl.

1 = de laatst gevolgde opleiding is een verzorgende beroepsopleiding

$0=$ de laatst gevolgde opleiding is geen verzorgende beroepsopleiding algemene. opl.

1 = de laatst gevolgde opleiding is een algemeen vormende opleiding

$0=$ de laatst gevolgde opleiding is geen algemeen vormende opleiding 
Schattingsresultaten kans op training voor schoolverlaters

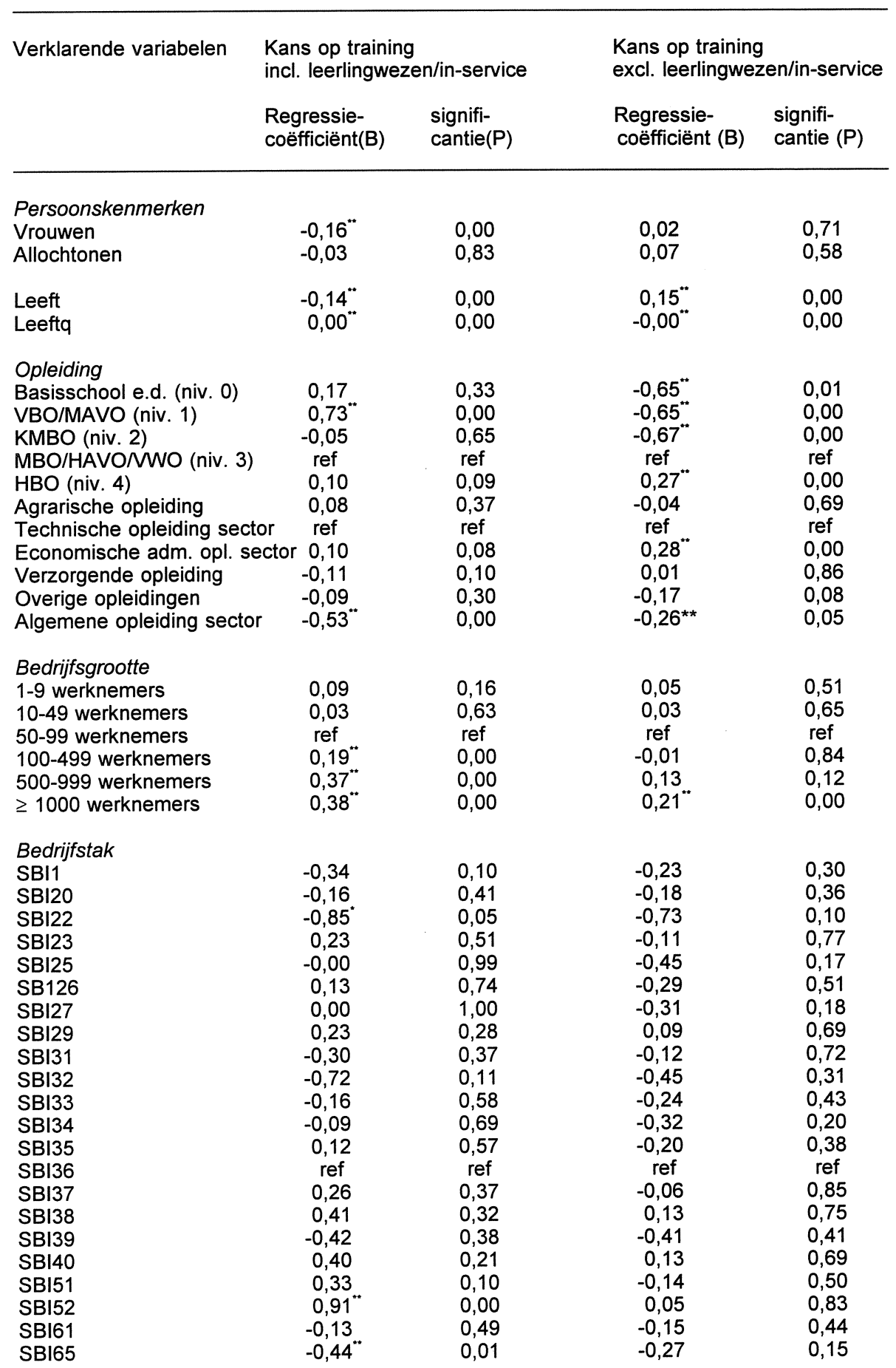


Schattingsresultaten kans op training voor schoolverlaters (vervolg)

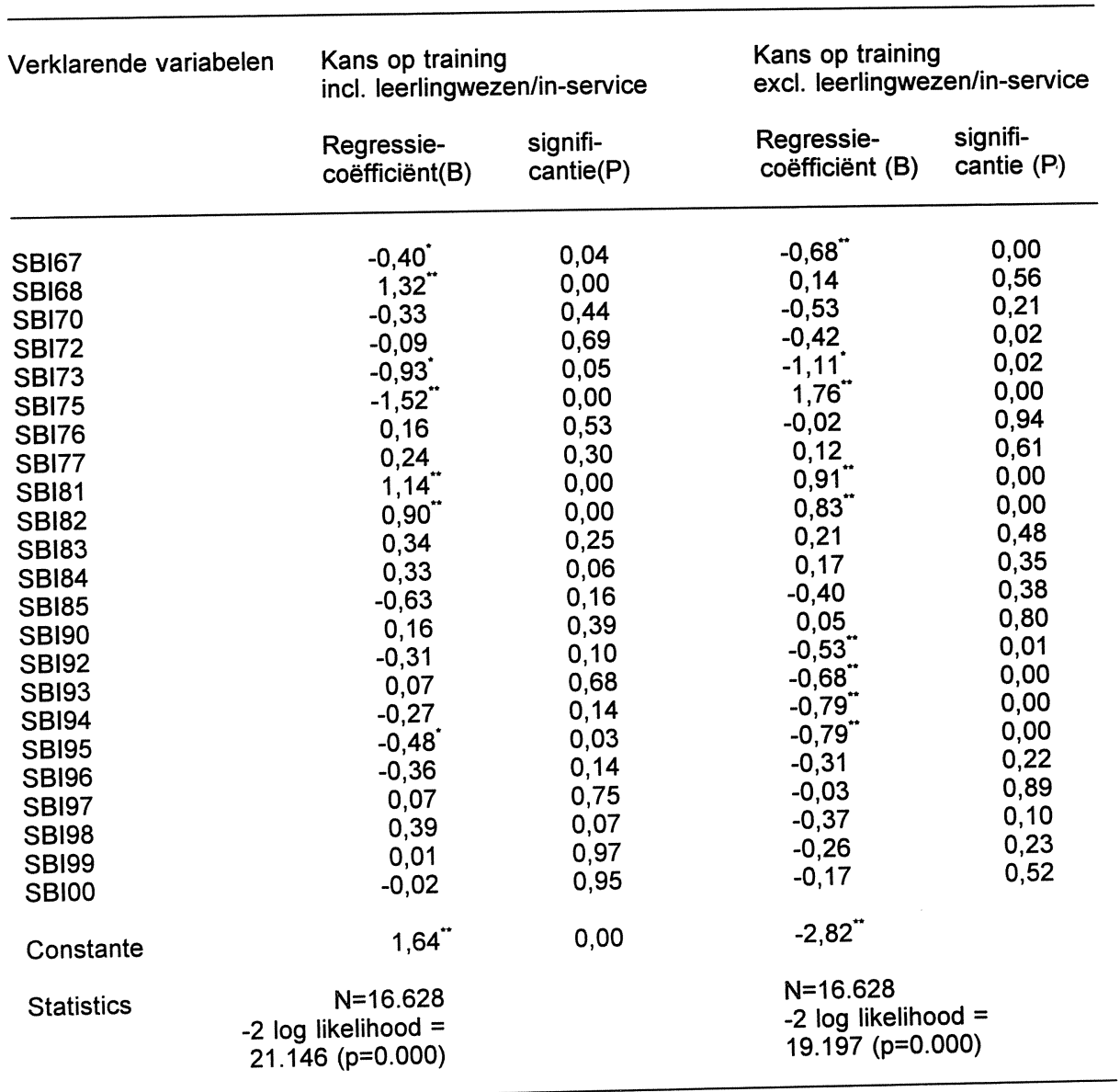

*: $p=<0.05$

**: $p=<0.01$ 
$\ldots$ 


\section{Bijlage III}

Human resource cycle van Tichy, Fombrun \& Devanna (1982)

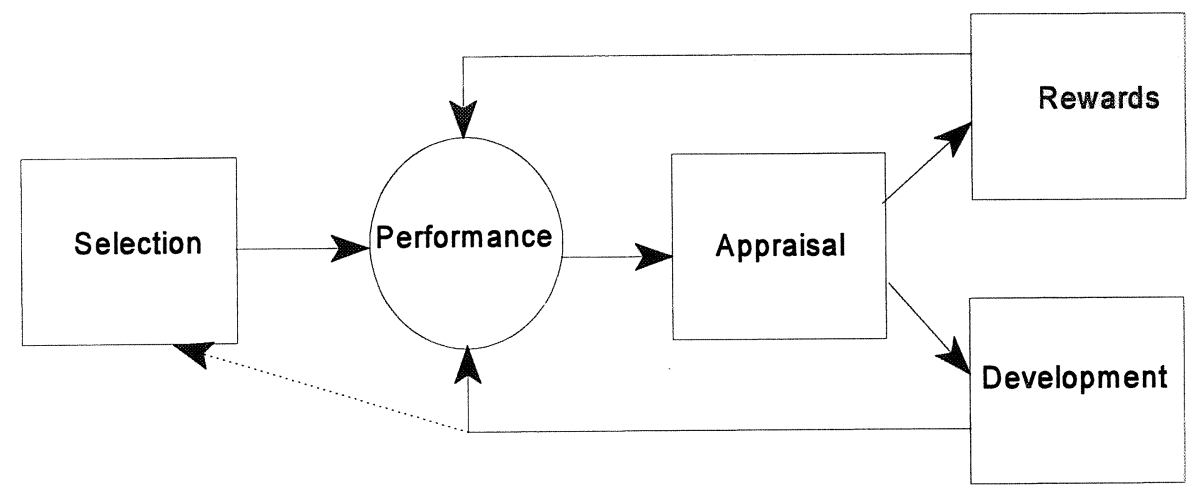

